\title{
USO DO SISTEMA DE VIGILÂNCIA EPIDEMIOLÓGICA NA AVALIAÇÃO E MONITORAMENTO DO PROGRAMA DE CONTROLE DA TUBERCULOSE
}

\section{LAEDI ALVES RodRIGUes dOS SANTOS}

Tese apresentada ao Departamento de Epidemiologia da Faculdade de Saúde Pública da Universidade de São Paulo para obtenção do Grau de Doutor.

ORIENTADORA:

Profa. Dra. Margarida Maria Mattos Brito de Almeida

São Paulo

2003 
$44591 / 2004$ doc

Autorizo, exclusivamente para fins acadêmicos e cientificos, a reprodução total ou parcial desta tese por processos fotocopiadores

Assinatura:

Data: 


\section{AGRADECIMENTOS}

Tantas foram as pessoas que me ajudaram neste trabalho, que posso me julgar privilegiada. Impossível agradecer a todas elas. Vou citar algumas - as outras, por favor, sintam-se também recebendo meu agradecimento e me perdoem.

Durante todo o tempo, contei com o apoio amoroso de toda a minha família. José Maria, meu marido, Daniel, André e Ana Rosa, filhos queridos, minha mãe Helle. Além de serem extremamente confiantes, sua participação ativa - Daniel sugerindo rumos e leituras, André e José Maria revisando, Rosinha fazendo a versão do resumo, foi decisiva para mim.

Professora Margarida - orientadora e amiga, tanta paciência e quantas foram minhas mudanças de rumo, nem sei como não desistiu!

Vera, companheira de estudo, trabalho e preocupações, me apoiou como chefe e, principalmente, como amiga.

Todos os colegas do CVE e da PRODESP, também incentivaram e me preservaram das demandas do trabalho - vou citar em ordem alfabética para que saibam serem todos muito queridos - Adriana, Araújo, Cecilia, Cida, Cláudia, Eugênia, Eva, Lourdes, Mariliza, Marinez, Necha, Pepita, Rodrigo, Vera Lúcia, Zelita.

Tive a sorte de contar com examinadores que, mais que ajudar na tese propriamente dita, me trataram com afeto e estimularam a melhorar, os professores: Péricles, com suas sugestões, além do apoio de amigo; Júlio César, que me ajudou com os instrumentos estatísticos, teve toda a paciência de ensinar e discutir comigo minhas dúvidas, que não eram poucas; Maria Inês e Helenice.

Quero agradecer também ao Prof. Gilberto Ribeiro Arantes, pela importância que teve em minha vida profissional e, particularmente, na origem deste trabalho.

Por fim, devo lembrar toda uma rede de pessoas que trabalham na vigilância da tuberculose com o sistema EPI-TB e que têm, com muito esforço, viabilizado a melhoria de qualidade do Programa de Tuberculose em São Paulo. 


\section{RESUMO}

Objetivo No contexto do Sistema Único de Saúde, é importante adotar novas formas de aproveitamento dos sistemas de informação existentes. Dados da vigilância de doenças de notificação compulsória podem ser úteis na gestão de programas de saúde. Este estudo teve como objetivo rever indicadores e elaborar novas maneiras de avaliar e monitorar o desempenho de municípios no controle da tuberculose.

Método - A partir de dados coletados na rotina de vigilância da tuberculose, foram construídos indicadores sintéticos de desempenho de um conjunto de municípios, referentes à busca de casos, diagnóstico e tratamento da doença. A confiabilidade dos indicadores foi testada pela estatística Alpha de Cronbach. Também foi feita a análise de agrupamento dos municípios à luz desses dois quesitos e elaborada uma carta de avaliação comparativa do desempenho. Resultados Para os indicadores parciais comparativos de qualidade do diagnóstico e do tratamento, foram obtidos Alphas em torno de $70 \%$ e de $60 \%$, respectivamente, sendo considerados aceitáveis. Para avaliação da busca de casos, o Alpha foi considerado insuficiente. Foi também construído o indicador sintético escalar ITB, com Alpha $=.6756$ segundo local de atendimento e .6392 por município de residência. A carta de avaliação, mostrando o desempenho do município relativo aos demais, pode ser especialmente útil para os gestores municipais, enquanto a análise de agrupamento facilita a gestão em âmbito estadual e federal. Conclusão É possível aproveitar dados do sistema de vigilância para construir indicadores escalares multidimensionais e instrumentos voltados para gestão do desempenho dos municípios no Programa de Controle da Tuberculose. 


\section{ABSTRACT}

Objective Having as frame of reference the Unified Health System (SUS), it is important to adopt new ways of reuse the existing data systems. The generated data from surveillance systems for diseases of compulsory notification can be useful to manage Public Health Programs. This study aimed to revise indicators and elaborate new manners of evaluating and supervising the municipalities' performances in the control of tuberculosis. Methods From routinely collected tuberculosis surveillance system's data, synthetic indicators were constructed for a pool of municipalities, addressing case-finding, diagnostic and treatment's quality of tuberculosis control program. Reliability of the indicators were tested by Cronbach's Alpha statistic. The cities were also clustered by these indicators, and it was elaborated a comparative graphic chart for monitoring their performance. Results Partial indicators have been elaborated to compare the diagnosis' quality, with Alphas around $70 \%$, and to compare the treatment's quality, Alphas around $60 \%$, which are considerated acceptable. Concerning to the search of cases, Alpha has been unsufficient. It has also been elaborated a sintetic scale indicator, the ITB, with Alpha $=6756$ according to the place of attendance, and = 6392 according to the place of residence. Evaluation letters, which shows the performance of a municipality in comparasion to the others, can be particularly useful to city managers, while the cluster analisys facilitates regional and national management. Conclusion It is possible to reuse the exisisting data of surveillance systems to elaborate multidimensional scale indicators and tools oriented to performance management for the participant municipalities of the Tuberculosis Control Program. 


\section{APRESENTAÇÃO}

A construção de um sistema de saúde que contribua para aumentar a qualidade de vida das pessoas, dar a elas a oportunidade de participar da vida social em melhores condições, depende do esforço de muitas pessoas. Uma das principais tarefas, nesse sentido, é mudar nossa maneira de lidar com a apreensão da realidade, aproveitando todas as informações produzidas, com o menor custo possível, tendo como horizonte os princípios do Sistema Único de Saúde.

O Programa de Controle da Tuberculose, de certa forma, é uma sentinela do que acontece no dia-a-dia do atendimento. Se os serviços de saúde de um município não detectam os sintomáticos respiratórios em tempo oportuno, com certeza também deixam passar um sem número de outras doenças, oferecendo medicação sintomática, de modo automatizado. Se a taxa de abandonos de tratamento é alta na tuberculose, provavelmente os hipertensos e diabéticos estarão também recebendo assistência de má qualidade. A diferença é que temos em mãos, sem que seja necessário introduzir novos instrumentos ou despender mais recursos, uma série de informações preciosas. Por que não nos utilizamos delas?

Trabalho há muitos anos na vigilância da tuberculose no Estado de São Paulo. Antes disso, trabalhei em vários Centros de Saúde e Distritos sanitários, na Capital e fora dela e sei do esforço necessário ao registro de dados. Na tuberculose, em meio às outras atividades, dedico atenção especial ao sistema de informações. Acompanhei o desenvolvimento do sistema de vigilância EPI-TB, ajudando a conceber desde a ficha de notificação até a computação dos dados, forma de análise e divulgação. Sempre me incomodou o desperdício de numerosos dados coletados, que muito poderiam contribuir para melhor compreensão do programa de controle nos municípios. Dado que a definição dos campos da ficha de notificação foi baseada na escolha de dados importantes no programa, por que isso ocorre?

Acho que temos conseguido progressos na tarefa de melhorar o sistema, tanto nos fluxos como na qualidade do registro. Mas é insuficiente a utilização dos dados para as decisões. Vejo que, apesar do esforço de toda uma rede de pessoas que participam do fluxo de informações neste sistema descentralizado, a análise ainda é limitada, 
reproduzindo a situação anterior ao EPI-TB, quando o sistema era centralizado e não atendia ao requisito oportunidade.

As iniciativas para melhorar a capacidade de análise dos dados, transformando-os em informações úteis na melhoria do controle da doença, muitas vezes esbarram na dificuldade em âmbito municipal e regional na interpretação dos dados. Apesar de estarem disponíveis nos diversos níveis do sistema, os municípios nem sempre conseguem avaliar esses dados e a atividade de vigilância tende a se tornar automática - notifica-se para atender às normas, sem que haja uma apropriação do conteúdo.

Este trabalho teve o propósito de construir instrumentos que tornassem mais fácil o monitoramento dos vários aspectos do PCT nos municípios, tanto para os responsáveis pela vigilância e controle da doença, como pelos gestores municipais e outras pessoas interessadas. Se houver sucesso nisto restará, ainda, verificar em que medida o melhor conhecimento da situação resultará em ações práticas para diminuir a carga social desta doença que há tanto tempo desafia a saúde pública. 


\section{ÍNDICE}

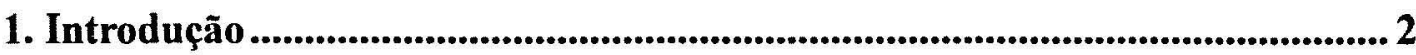

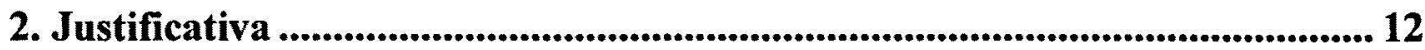

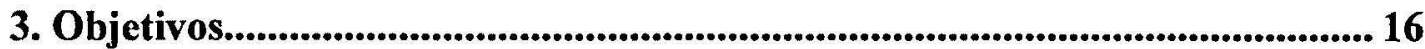

4. Material e Métodos ........................................................................................... 17

5. Resultados e discussão ........................................................................................... 27

5.1 Seleção e validação de indicadores .........................................................................27

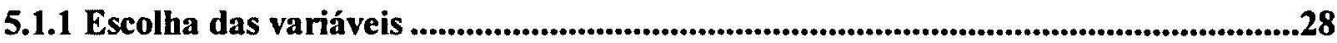

5.1.2 Avaliação da confiabilidade e construção de indicador sintético ...............................43

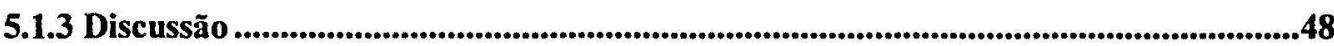

5.2 Agrupamento dos municípios segundo desempenho no PCT ...............................58

5.2.1 Agrupamento segundo municipio de residência .........................................................61

5.2.2 Agrupamento segundo municipio de atendimento ..........................................................62

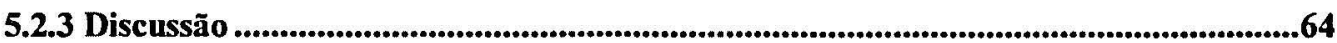

5.2.4 Características dos municípios e desempenho no PCT .............................................67

5.3 Carta de avaliação ......................................................................................................70

5.3.1 Construção das cartas gráficas comparativas ..............................................................70

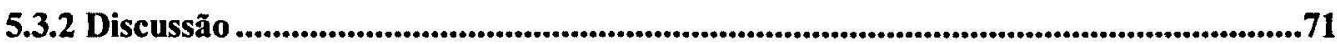

5.3.3 Exemplo de carta de avaliação....................................................................................75

6 Considerações finais......................................................................................................... 80

7 Conclusões .................................................................................................................... 89

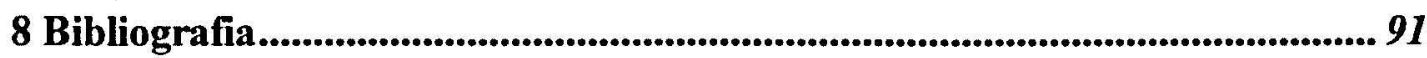




\section{Introdução}




\section{INTRODUÇÃO}

A implantação do SUS ${ }^{48}$ - Sistema Único de Saúde - trouxe consigo, ao lado dos beneficios evidentes de aproximação entre usuários e gestores municipais, questões cruciais sobre o papel da academia e dos níveis estadual e federal no acompanhamento e apoio a esses gestores ${ }^{24,64,89}$. É imperiosa a necessidade de se construir uma metodologia que identifique os pontos fracos e fortes de cada município, integrando os vários niveis de governo no esforço de melhorar a gestão do sistema de saúde e motivando ações em tempo oportuno.

Um dos maiores desafios na construção do SUS é incorporar a avaliação da vigilância epidemiológica e o monitoramento da qualidade de programas de saúde. Isso é extremamente necessário para que este sistema se desenvolva conforme os princípios de universalidade, equidade, integralidade, com a humanização do atendimento e participação social a que o SUS se propõe ${ }^{5}$.

Embora haja iniciativas para incluir indicadores epidemiológicos entre os critérios de transferência de recursos aos municípios, a prática de avaliação não é fácil. O desempenho dos municípios e os problemas locais são heterogêneos. Existem muitos os aspectos a serem focalizados e a análise simultânea deles no conjunto dos municípios não é simples. Formar juízo de valor sobre um grande número de municípios, em múltiplas dimensões, torna-se extremamente dificil e exige a adoção de formas para resumir seus respectivos desempenhos. Iniciativas de agrupamento por terem características semelhantes podem ser um valioso instrumento de gestão ${ }^{39}$. 
O problema da tuberculose é um dos exemplos. Uma extensa gama de variações regionais e a reorganização do setor saúde para instalação do SUS dificultam essa tarefa ${ }^{78}$ que, no entanto, é inadiável - em pleno século XXI, a tuberculose ainda faz parte do lamentável elenco de ameaças à saúde mundial ${ }^{26}$.

Contrariando expectativas ${ }^{4}$, constatou-se que não foi suficiente descobrir o agente infeccioso, métodos diagnósticos e tratamento eficaz ${ }^{25}$. Vários fatores se somaram para atrapalhar o controle desta doença, entre eles o surgimento da infecção pelo HIV, o aumento dos contatos interpessoais no mundo - efeito perverso da chamada "globalização", disseminando cepas do Mycobacterium tuberculosis resistentes aos medicamentos; o precário arsenal terapêutico conhecido; a desorganização dos sistemas de saúde; a exclusão social; a aglomeração de pessoas em presídios e em outras instituições ${ }^{21}$. Uma das prioridades da Organização Mundial da Saúde $26,49,67,99$, a tuberculose foi declarada "emergência mundial" em $1993^{52}$ e, mais recentemente, incluída em uma força-tarefa especial, iniciativa público/privada que já movimentou mais de US\$1500 milhões para financiamento do combate às doenças mais preocupantes, ao lado da Aids e da malária, em 154 programas de 93 países ${ }^{91}$. É um problema, portanto, que precisa ser acompanhado com muita atenção. A epidemia de tuberculose em Nova York foi um exemplo de que, para avançar no controle deste agravo, é preciso levar em conta o modo como são tomadas as decisões na política de saúde ${ }^{17}$. Foi muito apropriada a afirmação de $\mathrm{Pio}^{74}$ em 1989: “...estamos diante do desafio de trazer a um velho problema uma nova maneira de pensar".

Partindo-se dos conhecimentos atuais sobre a dinâmica epidemiológica da 
tuberculose, constata-se que os instrumentos hoje disponíveis para diminuir o problema se concentram principalmente em diminuir o período de transmissibilidade, detectando os casos precocemente e tratando-os de maneira adequada ${ }^{12}$.

Atualmente, a Organização Mundial da Saúde está absolutamente convencida de que a estratégia DOTS (Directly Observed Treatment Short-Course) é a melhor alternativa para se alcançar sucesso no $\mathrm{PCT}^{99}$. Cinco pilares a integram: 1.compromisso político; 2.uso de esquema medicamentoso adequado com abastecimento regular de medicamentos; 3.busca de casos com diagnóstico por exame bacteriológico; 4.supervisão direta da ingestão dos medicamentos ; 5.sistema de informação para monitoramento dos resultados.

As intervenções em que se baseia a estratégia DOTS, são a busca de casos bacilíferos e seu tratamento. Melhor dizendo, em ordem de prioridade, o tratamento figura em primeiro lugar, seguido pela procura de casos bacilíferos entre pessoas que se apresentem espontaneamente aos serviços de saúde por causa dos sintomas. Uma revisão recente mostra que estes princípios, defendidos há mais de 30 anos por Karl Styblo ${ }^{88}$, continuam sendo as bases em que o controle da tuberculose se apoia, principalmente nos países de recursos limitados ${ }^{76}$.

Até mesmo onde o nível de renda é considerado médio, a prioridade para essas atividades é indiscutível ${ }^{12}$. Outras intervenções, como o tratamento de casos com baciloscopia negativa, a busca ativa de casos fora dos serviços de saúde e a quimioprofilaxia para HIV-positivos, podem apresentar bons resultados em determinadas condições, embora sua relação custo-efetividade seja bem menor. A quimioprofilaxia, embora eficaz na diminuição do risco de adoecimento em 
infectados, esbarra em dificuldades práticas para detectar possíveis alvos e, principalmente, para garantir a adesão, o que limita seu papel na redução da carga da doença. A vacinação com $\mathrm{BCG}$, outra medida também focalizada em diminuir o risco de adoecimento, tem impacto limitado ${ }^{76,12}$.

O Ministério da Saúde selecionou, em conjunto com os Estados, cerca de 250 municípios prioritários para tuberculose ${ }^{45,30}$, mas não se definiu metodologia que permita avaliar seu desempenho ou acompanhar em detalhes o problema em cada um deles ${ }^{46}$.

Avaliação pressupõe a formação de um juízo de valor, um padrão a ser atingido, a comparação com o ideal ou com uma meta. Mas um dos grandes problemas na avaliação de programas de saúde é: comparar com que ${ }^{13,55,61}$ ? Este é um ponto que tem sido crucial no controle da tuberculose.

O Programa de Controle da Tuberculose (PCT) tem trabalhado com metas fixas e em número reduzido, sendo as mais consensuais a taxa de cura esperada, a quantidade de sintomáticos respiratórios a serem examinados e o número de casos a serem descobertos ${ }^{46,53,99}$. As estimativas são muitas vezes arbitrárias e as metas são padronizadas tendo por base, freqüentemente, parâmetros pouco consistentes. Por exemplo: como saber qual o número de casos não descobertos pelo sistema de saúde, se a estimativa de casos existentes ${ }^{47,56,70}$ é controversa?

Em tuberculose, como na maioria dos programas de saúde, a avaliação tradicional se baseia na comparação com essas metas preestabelecidas, padrões definidos como "ideais" 22, 63, 87, 90 Essa tarefa não é tão fácil quanto parece. O que pode ser considerado bom, e quanto se pode melhorar? Quais são os parâmetros? 
Como medir o percurso, determinar quanto se conseguiu progredir? Como estabelecer metas para situações desiguais?

A tarefa passa a ser dificil - compara-se o resultado obtido com uma meta dita "ideal", extraída da literatura, raramente proveniente de dados de locais onde a situação é semelhante. Na maioria das vezes, as metas não levam em conta as condições reais de cada serviço ou local avaliado e, por isso, podem tender à falsa noção de que os condicionantes são homogeneamente distribuídos. A busca de resultados inatingiveis, freqüente na prática dos programas de saúde, leva à descrença: fica a certeza de que, por mais que se faça, nunca se conseguirá chegar ao desejado.

Além disso, o próprio processo de assistência médica é de dificil mensuração ${ }^{14,62}$. Utilizam-se indicadores que podem refletir tanto a gravidade da situação epidemiológica, quanto problemas na assistência médica ou no sistema de informação. É o caso, por exemplo, do coeficiente de incidência. Sendo um indicador construído com base nos casos informados, o valor encontrado é passivel de múltiplas interpretações. Não é rara a divulgação na imprensa de uma dita "piora" na situação da doença quando algum município, incentivando a busca de casos, apresenta aumento do número destes em relação ao ano anterior. Tantas vezes esse engano ocorreu, que muitos propõem ${ }^{46}$ que seja usado o termo "coeficiente de detecção" e não "coeficiente de incidência" para os dados provenientes das notificações - este indicador é importante para se analisar a tendência da doença, e pode auxiliar na compreensão da situação da tuberculose no município, porém devem ser tomados os devidos cuidados na sua interpretação. 
Acresce, ainda, um outro problema: como se pode sintetizar o resultado de uma avaliação, quando estão envolvidos variados indicadores, com diferentes unidades de medida, sendo que nenhum deles é suficiente para retratar a qualidade do programa? Para medir a qualidade da atuação em um programa de saúde é interessante dispor de uma medida sintética escalar que dê conta de responder à pergunta: afinal, o desempenho deste local (serviço de saúde, município, hospital) é bom?

No caso do controle da tuberculose em municípios, pode-se imaginar como é complicado formar um juízo de valor desse tipo: a multiplicidade de atores envolvidos no processo, desde a deteç̧ão do caso até o seu desfecho, os determinantes políticos e a rede de serviços de saúde são algumas das dimensões que fazem parte da rede de causalidade de sucesso ou fracasso do programa. Vale lembrar que, para resultar em mudança, o conteúdo e a forma de apresentação da informação devem ser talhados de acordo com o usuário - especialmente quando esse usuário detém poder de decisão sobre o direcionamento de esforços e recursos para várias áreas que competem, como ocorre na esfera municipal.

Mas uma escala que possa sintetizar uma avaliação de desempenho ainda não seria suficiente. Saber se determinado programa de saúde está sendo bem desempenhado ajuda, mas não dá conta da questão do monitoramento, não mostra em detalhes quais as falhas e onde se deve intervir ${ }^{80}$, limitando-se a ser superficial, sem apontar caminhos para a melhora. A avaliação por metas, em âmbito nacional e internacional, pouco contribui para esclarecer àqueles que podem efetivamente melhorar o programa. As informações, quando são devolvidas, não detalham quais os 
pontos onde há falhas e têm um grau de agregação que não permite formar opinião conclusiva.

Dadas estas dificuldades, uma alternativa para avaliação de desempenho é a aplicação de metodologia que, ao contrário da tradicional, que fixa metas a serem atingidas, se baseia na comparação entre pares. Esta forma foi bastante utilizada no Japão, pelo Instituto de Pesquisas de Tuberculose (Research Institute of Tuberculosis Control, RIT), há mais de $30 \operatorname{anos}^{9}$. Pela sua facilidade de compreensão, ela se presta à comparação entre os diversos serviços de saúde. Isso porque se utiliza de um estratagema simples: padronizando os valores para uma escala $z$, a unidade de medida de todos os indicadores é uma unidade comum - o desvio-padrão. A apresentação gráfica dos dados encontrados facilita a interpretação, detectando-se imediatamente valores que se afastam da média em determinado serviço de saúde.

Sendo assim, uma rápida observação da carta de avaliação de um Centro de Saúde mostra, por exemplo, que o serviço é mais eficiente do que a média na taxa de cura, mas está entre os que menos utilizam a cultura como método de diagnóstico, ou que a média de demora na descoberta está muito acima da média. A carta, então, é um eficiente instrumento para a supervisão indireta do desempenho dos serviços, prestando-se à avaliação comparativa entre os mesmos.

Em fins da década de 1980, foi implantado um projeto-piloto, por iniciativa de docentes da Faculdade de Saúde Pública da Universidade de São Paulo. Este trabalho, nos moldes do sistema de vigilância do Japão, foi realizado pelo Núcleo de Investigações em Vigilância da Tuberculose (NIVE-TB/FSP) ${ }^{11}$ e envolveu parte do município de São Paulo, vários municípios da região metropolitana de São Paulo e o 
Município de Campinas.

Para definir quais seriam os tópicos a serem incluídos nas fichas de notificação de caso de tuberculose, foram feitas reuniões, com participação de técnicos da coordenação do programa de tuberculose e vigilância epidemiológica da Secretaria da Saúde e de serviços de referência. Naquela ocasião, foram definidos primeiramente quais os indicadores de importância para o controle da tuberculose ${ }^{11}$. Foi então desenhada uma nova ficha de investigação da tuberculose. A escolha dos dados que constariam na ficha de notificação de tuberculose teve como princípio incluir variáveis que se prestassem a originar aqueles indicadores. Foi também testado um boletim de acompanhamento mensal para registro de informações relativas ao acompanhamento dos casos até seu encerramento, em paralelo ao sistema de vigilância estadual, cujos dados eram processados de forma centralizada em computador de grande porte. A experiência do NIVE-TB/FSP foi bastante interessante, provando ser possível conjugar a avaliação de indicadores epidemiológicos com o monitoramento das ações de controle.

Trabalhos publicados pelo NIVE-TB ${ }^{6,7,81}$, seguindo a metodologia aplicada pelo RIT, sugeriram a construção de uma carta comparativa semelhante à do Japão para serviços de saúde do Estado de São Paulo ${ }^{10}$. Mas essa metodologia, embora tenha produzido análises muito interessantes, não foi aplicada na rotina de avaliação do PCT, por razões de natureza operacional.

No ano de 1991, a Secretaria de Estado da Saúde de São Paulo incorporou, com algumas modificações, a ficha de notificação proposta pelo NIVE-TB/FSP.

Em 1998, foi desenvolvido e implantado em todo o Estado o EPI-TB ${ }^{82}$, 
sistema para computação dos dados obtidos pela notificação obrigatória de doenças, utilizando como base o aplicativo Epi Info ${ }^{15}$, desenvolvido no Estado de São Paulo em conjunto, pelo Centro de Vigilância Epidemiológica "Prof. Alexandre Vranjac", e a Companhia de Processamento de Dados de São Paulo (PRODESP). Substituiu-se o sistema anterior, centralizado, por um fluxo de dados onde o registro de dados em computador se inicia em serviços de saúde - ambulatoriais e hospitalares, secretarias municipais ou Direções Regionais de Saúde, conforme a capacidade de recursos humanos e de informática de cada local. A evolução dos casos passou a ser atualizada mensalmente, por meio de um boletim de acompanhamento. A intenção era que o banco de dados ficasse o mais próximo possível do local onde esses dados se originam, de forma que pudesse estar acessível, sempre que necessário, em tempo oportuno.

Nessa ocasião, a ficha de notificação foi revista, sendo redefinidos quais os dados de acompanhamento de importância para o controle da tuberculose. Levaramse em consideração as condições dos serviços de saúde, como por exemplo a disponibilidade de exames laboratoriais no Estado. A definição dos dados que constam na ficha de notificação de tuberculose manteve como princípio, portanto, incluir variáveis que se prestassem a originar indicadores importantes na compreensão da epidemiologia da doença e das medidas de controle, no que se refere à incidência e distribuição dos casos, na descoberta de casos e em sua condução no processo de cura, evidenciando também possíveis fatores de risco.

Ocasionalmente, a ficha de notificação sofreu alterações, sempre tendo em 
vista o acompanhamento de tendências da doença, seus fatores de risco e o desempenho do PCT. Como exemplo, além dos dados sobre a forma de apresentação dos pacientes e a demora até iniciar o tratamento, já incluídos desde o convênio entre a Secretaria de Estado da Saúde de São Paulo e o NIVE-TB, outras variáveis importantes vêm sendo computadas, como os resultados de testes de resistência, o tipo e o vínculo institucional do serviço que descobriu o caso e fatores de risco relacionados à ocupação do paciente.

Atualmente, os dados de cada uma das 24 Direções Regionais de Saúde são enviados em meio magnético para o Centro de Vigilância Epidemiológica da Secretaria de Estado da Saúde, onde são reunidos. Com a descentralização do registro das notificações, os municípios passaram a dispor de seus bancos de dados, possibilitando a tomada de decisões em tempo oportuno. Mas nem sempre isso acontece, e uma das razões disso pode ser a dificuldade na interpretação dos dados ${ }^{80}$.

É sabido que a devolução de informações devidamente processadas e avaliadas é um ponto fraco da maioria dos sistemas de vigilância de doenças ${ }^{3}$ e este programa não é exceção. Apesar da grande quantidade de dados coletados, poucos são habitualmente analisados. O sistema de vigilância é subutilizado: apesar de definidos com vistas à obtenção de indicadores, a maior parte dos dados colhidos dificilmente são levados em conta para a tomada de decisões.

Para conduzir um programa de controle, entretanto, é interessante que os responsáveis possam se apropriar de todas as informações relevantes. Mas, para que isso seja efetivado, é preciso que estas sejam de fácil obtenção e análise, criando-se alternativas práticas para torná-las disponíveis ${ }^{80}$. 
2. Justificativa 


\section{JUSTIFICATIVA}

Donebedian ${ }^{23}$ propôs que a avaliação de cuidados em saúde fosse dividida em análise de estrutura, processo e resultado. Por estrutura se compreende tudo o que é necessário em termos de recursos humanos, materiais e financeiros para as ações e procedimentos a serem avaliados. Variáveis como a prescrição de tratamento adequado quanto aos medicamentos, duração e dosagem e as interações médicopaciente são classificadas como de processo, enquanto resultado indica a condição do paciente durante ou depois do tratamento. Um programa de boa qualidade pode ser definido, portanto, como aquele cuja estrutura e processo levam aos resultados desejados.

Para o Programa de Tuberculose, resultados desejáveis incluem a redução do sofrimento e mortes por tuberculose, bem como a interrupção da cadeia de transmissão da doença, com diminuição da incidência, da mortalidade e a redução da prevalência de resistência aos medicamentos.

No entanto, esses resultados são de longo prazo e não inteiramente atribuíveis à ação das medidas de controle da área de saúde. Um resultado medíocre não necessariamente implica que a qualidade das ações do programa seja ruim, e vice-versa. A incidência, por exemplo, pode aumentar pela deterioração de condições externas ao setor saúde, como ocorreu durante o período das guerras na Europa ${ }^{69}$. Pode também refletir fenômenos que, embora relacionados à saúde, são até certo ponto independentes da má condução do programa de controle específico ${ }^{75}$, caso da recente epidemia de infecção pelo $\mathrm{HIV}^{33}$. Inversamente, a mortalidade diminuiu na Inglaterra e outros paises da Europa na primeira metade do século XX, mesmo antes 
da descoberta de medicamentos eficazes ${ }^{88}$. Conhecendo esta dificuldade, o próprio Donabedian ${ }^{23}$ propôs que o resultado seja, alternativamente, separado em resultados de procedimentos (situação do paciente durante e após a intervenção) e impacto (efeitos sobre a situação de saúde quanto ao problema em foco).

Fauman ${ }^{29}$ sugeriu que, ao definir os critérios de avaliação de qualidade seja seguida a seqüência dos cuidados médicos nas etapas (diagnóstico, tratamento) que os pacientes percorrem. O mesmo raciocínio se observa no modelo lógico proposto pelo Centers for Disease Control and Prevention ${ }^{2}$.

A partir dessas premissas, foi analisado o fluxo percorrido pelos pacientes até a cura, com os principais requisitos para um bom desfecho dos casos e conseqüentes efeitos sobre a situação da doença.

Tendo em vista que, na atual situação do SUS, os municípios são peças fundamentais para a execução das ações de assistência à saúde, assim como vigilância e controle das doenças; mas sabendo-se também que, em geral, não há recursos humanos suficientes e a atividade de vigilância das doenças tende a ser realizada por pessoas que têm múltiplas obrigações e responsabilidades, há necessidade de facilitar a tarefa de avaliação e monitoramento dos programas de saúde. As análises de desempenho devem ser endereçadas primordialmente àqueles que detêm o poder de tomar decisões sobre o programa e, além das equipes de vigilância da doença, os secretários municipais de saúde são um público-alvo preferencial. Dado que o tempo, para estas pessoas, é quase sempre escasso, instrumentos de devolução de informações precisam ser de fácil interpretação. Como premissa, o sistema de devolução dos dados deve ser suficientemente simples e claro 
para ser utilizado na rotina da vigilância, fornecendo subsídios em tempo oportuno para decisões. A comparação entre os municípios pode ser frutífera, estimulando a melhora do desempenho de cada um.

Propõe-se, neste trabalho, a validação de indicadores de avaliação, com a construção de uma escala pela qual se possa obter uma medida sintética do desempenho do programa do PCT em âmbito municipal e a elaboração de uma carta comparativa de desempenho de municípios, passível de ser utilizada rotineiramente no Estado de São Paulo.

A carta de avaliação é um instrumento dirigido primordialmente aos gestores municipais e outros usuários das informações em âmbito municipal. Para uso dos gestores em nível estadual e federal, também é urgente que se elaborem instrumentos para conhecer a qualidade das intervenções nos municípios, sintetizando a multiplicidade de dados existentes e facilitando sua interpretação. Nesse sentido, pretende-se também verificar como os municípios do Estado de São Paulo podem ser agrupados segundo qualidade de atuação no controle da tuberculose.

Espera-se, com isso, poder avançar no processo de monitoramento do processo e resultados do PCT, tornando mais fácil a tarefa de interpretar quais os pontos positivos e negativos dos municípios neste programa e traçar estratégias adequadas para melhoria. 
3. Objetivos 


\section{OBJETIVOS}

\section{Objetivo geral}

Rever indicadores e elaborar novas formas de avaliação e monitoramento do desempenho de municípios do Estado de São Paulo no Programa de Controle da Tuberculose.

\section{Objetivos específicos}

- Selecionar e validar variáveis apropriadas para a construção de uma escala para avaliação e monitoramento de desempenho de municípios do Estado de São Paulo quanto ao controle da tuberculose.

- Comparar os municípios entre si, agrupando-os segundo semelhanças em relação aos pontos principais do PCT.

- Elaborar instrumento que possa ser implantado na rotina de monitoramento do PCT nos municípios, propiciando a detecção dos pontos fracos e fortes do programa em comparação com os demais municípios do conjunto.

- Propor mudanças no sentido de otimizar a utilização dos dados das notificações e acompanhamento dos resultados de tratamento no sistema de vigilância da tuberculose no Estado de São Paulo. 
4. Material e Métodos 


\section{MATERIAL E MÉTODOS}

a) Revisão das prioridades do Programa e escolha do rol de variáveis indicativas

Como primeiro passo para elaborar indicadores, foram revistas quais as premissas necessárias para que o controle da tuberculose possa ser efetivo, à luz das evidências científicas, da situação atual da doença e das ações de controle no Estado de São Paulo.

Partiu-se de dados secundários já disponíveis do sistema de vigilância da tuberculose do Estado de São Paulo, contidos no banco de dados do "EPI-TB", baseado nas notificações de casos de tuberculose.

A população-alvo do estudo foi constituída pelos municípios do Estado de São Paulo com mais de 100 mil habitantes em 2002 ${ }^{67}$. Dos 62 municípios nessa condição, foram excluídos da análise:

- Município de São Paulo, que por sua dimensão julgou-se que deve ser avaliado à parte;

- Campinas, por não utilizar o sistema EPI-TB;

- Três outros municípios do interior do Estado, que apresentavam mais de $20 \%$ dos casos sem registro de encerramento no banco de dados EPI-TB, dado que o desfecho de cada tratamento é de fundamental importância para avaliação da efetividade do PCT. Vale lembrar que a taxa de preenchimento desses dados, acima de $80 \%$ em todos os outros 57 municípios, pode ser considerada bastante 
satisfatória.em se tratando de um sistema de vigilância ${ }^{1}$.

Tendo em vista a grande mobilidade no sistema prisional, que resulta em transferências de presos sem o conhecimento do sistema de saúde e escapa ao domínio deste, e para não falsear a situação da tuberculose em cada região, decidiuse não incluir os detentos como residentes em nenhum dos municípios.

No total, o conjunto de 57 municípios que fizeram parte deste estudo concentrou 7204 casos novos notificados no ano 2002 , sendo responsáveis por $40,5 \%$ da incidência de tuberculose no Estado. Somados aos 7348 casos da Capital, esses municípios abrangem $81,8 \%$ dos casos novos notificados, enquanto todos os demais municípios, em número de 583, foram responsáveis por apenas 19,2\%.

Outro motivo que justifica a escolha deste conjunto de municípios é a magnitude dos coeficientes de incidência - levando-se em consideração que a tuberculose incide preferencialmente nos aglomerados urbanos - nestes a oportunidade de disseminação desta doença é maior que nos pequenos centros - a prioridade deve ser voltada aos maiores municípios ${ }^{84}$.

Um dos propósitos do trabalho foi melhorar o aproveitamento dos dados já coletados pelo sistema de vigilância epidemiológica utilizado na rotina estadual, sem a necessidade de pesquisas especiais ou alteração do fluxo de informação existente. Sendo assim, foram identificadas quais as informações disponiveis sobre os tópicos mais importantes do PCT nos bancos de dados mencionados, candidatas a compor o indicador sintético de desempenho dos municípios.

Da análise desses dados foram selecionadas variáveis que preenchessem os 
seguintes requisitos:

- Respaldo de conhecimentos científicos e normas do PCT, aceitas nacional e internacionalmente.

- Relevância quanto aos objetivos do PCT;

- Adequação ao porte dos municípios - eventos presentes em pelo menos $5 \%$ do total de casos;

- Disponibilidade e facilidade de obtenção.

Constituiu-se, então, um conjunto de indicadores básicos de processo e resultado a serem testados como potenciais componentes dos indicadores sintéticos. Para cada um deles, foi definida a fórmula de cálculo.

Todos os indicadores selecionados são quantitativos e foram expressos na forma de porcentagem de casos que satisfazem a determinada condição. Assim, por exemplo, o indicador de demora entre o início dos sintomas e o inicio do tratamento foi calculado como "porcentagem de casos com demora menor ou igual a 8 semanas", e não como "demora média dos casos"; o controle bacteriológico dos pacientes foi expresso em "porcentagem de casos baciliferos com duas ou mais baciloscopias de controle" e não como "número de baciloscopias por paciente bacilifero". Foram escolhidas variáveis que tivessem sempre o sentido positivo para aumento de qualidade, para facilitar a compreensão gráfica de seu significado nas cartas de avaliação.

Optou-se por analisar os casos que ocorreram em 2002. Para as variáveis 
referentes ao tratamento, foram considerados os casos de 2001, seguindo-se a orientação da Organização Mundial da Saúde, que recomenda que os resultados de tratamento sejam avaliados no ano subsequente ao da incidência.

Os dados foram computados pelo software EPI-INFO, de duas formas: segundo município de residência dos casos e segundo município de atendimento.

\section{Validação dos itens e construção de indicador sintético}

A confiabilidade de um indicador-resumo pode ser definida como o quanto os itens que o compõem medem a mesma característica. A razão de selecionar variáveis é identificar quais delas têm essa qualidade, ou seja: são compatíveis entre si no sentido de medirem o mesmo atributo.

Essa consistência interna, no caso de indicadores com múltiplas respostas, pode ser avaliada por uma estatística denominada Alpha de Cronbach ${ }^{72}$, calculada com uso de pacotes estatísticos, cuja fórmula é a seguinte:

$$
\alpha=\frac{k \operatorname{cov} / v a r}{1+(k-1) \operatorname{cov} / v a r}
$$

onde

$\boldsymbol{k}=$ Número de variáveis

$\operatorname{cov}=$ Média das covariâncias

var $=$ Média das variâncias

Parte-se dos valores de um conjunto de variáveis em uma amostra da população a ser avaliada. Essas variáveis, previamente selecionadas por terem 
respaldo em estudos científicos ou em normas e recomendações oficiais, serão submetidas a esse teste estatístico, que leva em conta a variância de cada item em comparação com a variância do conjunto dos demais itens.

Para se obter o Alpha de Cronbach, o primeiro procedimento é a análise da matriz de correlação dessas variáveis. Como a premissa desta estatística é que todos os componentes do indicador se correlacionem positivamente, pode ser necessário desprezar alguns itens, para que nenhum deles tenha correlação negativa com qualquer outro. [Isto realmente ocorreu, restando 2 itens compatíveis entre si para intensidade de busca de casos, 2 para qualidade do diagnóstico e 4 do tratamento, como se verá adiante, no capítulo resultados].

Analisou-se inicialmente a matriz de correlação dos valores dos itens relativos à etapa busca de casos em cada um dos os municípios. Foram então selecionadas as variáveis compatíveis, tanto com os dados obtidos segundo município de residência como por município de atendimento dos casos, para a dimensão busca de casos.

Em seguida, o mesmo procedimento foi aplicado às variáveis relativas ao aspecto diagnóstico e também ao tratamento, obtendo-se também dois conjuntos de itens, respectivamente por local residência e por atendimento, para cada uma dessas dimensões.

Uma vez determinados quais os itens compativeis, verifica-se, no teste estatístico como cada item se correlaciona com o conjunto dos demais, e calcula-se o Alpha de Cronbach. Quanto maior o valor do Alpha de Cronbach, que varia de 0 a 1 , maior a consistência entre os itens. Uma interpretação dessa estatística seria o quanto 
do fenômeno avaliado é representado pelo conjunto de itens ${ }^{60}$. Assim, um Alpha próximo da unidade indica que o conjunto de variáveis reflete fielmente o fenômeno.

Para cada uma das três dimensões do PCT aqui consideradas, foram então calculados indicadores sintéticos parciais:

- Um indicador sintético parcial para intensidade da busca de casos, o Indicador de Tuberculose para qualidade na busca de casos, o qual foi denominado ITB-в.

- Um indicador sintético parcial para qualidade do diagnóstico, o Indicador de Tuberculose para qualidade de diagnóstico, denominado ITB-D.

- Um indicador sintético parcial para qualidade do tratamento, o Indicador de Tuberculose para qualidade do tratamento, aqui chamado ITB-T.

Além desses indicadores parciais, foi também construído um indicador escalar comparativo para qualidade do PCT como um todo, o ITB.

Para os indicadores parciais, foi calculada a média simples dos valores padronizados ("z-scores") dos itens validados pelo Alpha de Cronbach das dimensões envolvidas.

Assim, a fórmula para estes indicadores parciais é a seguinte:

$$
\begin{aligned}
& I T B-B=\sum\left[z\left(B_{1}\right)+z\left(B_{2}\right)+\ldots+z(B n)\right] / n \\
& I T B-D=\sum\left[z\left(D_{1}\right)+z\left(D_{2}\right) \ldots+z\left(D_{n}\right)\right] / n \\
& I T B-T=\sum\left[z\left(T_{1}\right)+z\left(T_{2}\right)+\ldots+z(T n)\right] / n
\end{aligned}
$$


onde

$\boldsymbol{B} \boldsymbol{n}=$ variáveis validadas para busca de casos

$\boldsymbol{D n}=$ variáveis validadas para diagnóstico

$\boldsymbol{T n}=$ variáveis validadas para tratamento

$\boldsymbol{n}=$ número de variáveis que foram validadas no quesito

Para a construção do indicador sintético ITB, utilizou-se o mesmo procedimento de validação para seleção das variáveis. Assim, o ITB foi construído como:

$I T B=\sum\left[z\left(V_{1}\right)+z\left(V_{2}\right)+\ldots+z(V n)\right] / n$

onde:

$\boldsymbol{V n}=$ variáveis validadas para indicador sintético de desempenho no PCT $\boldsymbol{n}=$ número de variáveis que foram validadas para composição do indicador

Note-se que o ITB não partiu dos indicadores parciais - foi reiniciado o procedimento de seleção das variáveis, como se aqueles não tivessem sido calculados. Os motivos para esta opção foram: a confiabilidade insuficiente para busca de casos, como será descrito nos resultados, e a constatação da possibilidade de agregar indicadores compatíveis, relacionados ao diagnóstico e ao tratamento.

O cálculo da matriz de correlação, do Alpha de Cronbach e do indicador sintético foi realizado com auxílio do aplicativo $\operatorname{SPSS}^{72}$. 


\section{Agrupamento dos municípios segundo semelhanças no desempenho}

Com vistas a verificar qual a distribuição dos municípios no conjunto, utilizou-se a técnica de agrupamento em "clusters". Este procedimento analisa a proximidade nos valores obtidos pelos elementos em cada uma das dimensões analisadas, tomando como ponto de partida a distância entre os dois elementos que apresentem valores mais próximos ${ }^{77}$. A seguir, determina a distância entre o ponto médio entre estes e o elemento mais próximo, e assim por diante. Verificando qual a distância geométrica (euclideana) dos valores obtidos, esta estatística agrupa os elementos (no caso, os municípios) para os indicadores testados.

A definição do número de agrupamentos a ser considerado é bastante intuitiva, com base na observação de um dendograma que mostra graficamente quão próximos estão os valores dos municípios nos indicadores utilizados para agrupá-los. Opta-se pelo número de agrupamentos pela observação do dendograma e segundo a conveniência: quanto maior a exigência de semelhança, maior o número de grupos considerados.

Um desdobramento em muitos grupos tem a vantagem de serem os indivíduos de um mesmo grupo mais semelhantes. No caso deste estudo, a desvantagem de se optar por um grande número de grupos seria a dificuldade de dar acompanhamento diferenciado a cada grupo. No limite, é claro, pode-se considerar que os municípios sejam todos diferentes entre si, formando 57 grupos de um município cada. Ou, na escolha oposta, dizer que há um só grupo de todo o conjunto de municípios, situação em que não haveria a preocupação com as diferenças. Entre esses extremos, escolhe-se a opção mais conveniente, conforme a apresentação no 
dendograma.

Assim, detectando situações semelhantes, a técnica permite neste estudo identificar grupos de municípios que, provavelmente, demandam o mesmo tipo de intervenção e podem ser abordados em conjunto.

Os municípios foram agrupados segundo desempenho nos dois indicadores sintéticos parciais: o ITB-D, que resume desempenho no diagnóstico, e o ITB-r, relacionado à qualidade do tratamento. Em seguida, os dados foram plotados num gráfico bidimensional tendo como eixos esses indicadores. Foram construídos quatro gráficos: dois gráficos (por município de residência e atendimento) com os valores médios dos grupos no ITB-D e ITB-T, e dois gráficos onde foram plotadas as coordenadas de cada município nessas dimensões.

O agrupamento dos municípios em "clusters", produzindo o gráfico do tipo dendograma e depois plotando os valores de cada município e dos grupos resultantes, também foi feito com auxilio do software SPSS.

\section{Construção de cartas gráficas comparativas}

Para monitoramento do PCT foram construídas cartas que mostram graficamente a classificação do municipio em comparação com os demais. Para isso, foi utilizada a comparação do valor obtido em cada variável no "ranking" dos municipios avaliados, em faixas que correspondem ao quintil de valores do conjunto de municípios.

Como o conjunto teve 57 componentes, optou-se por aproximar o cálculo seriam 11,4 municípios em cada quinto, mas foram consideradas, para as 5 faixas de 
valores, 4 extremas com dez municípios cada uma e uma central com os 17 municípios restantes. Esse procedimento foi adotado para facilitar o entendimento dos resultados pelos gestores municipais e outros usuários das informações - é mais fácil explicar, por exemplo, que os valores obtidos pelo município $\mathrm{X}$ em tal ou qual atributo ficaram "entre os dez maiores", "entre os vinte maiores", "entre os dez menores" no conjunto dos municípios com mais de 100 mil habitantes, do que dizer que estão no primeiro, no segundo ou no último quinto. Este tópico foi obtido utilizando o aplicativo EPI-INFO.

A classificação dos valores em categorias foi codificada por asteriscos localizados à esquerda para o grupo dos municípios com o pior desempenho no indicador, e à direita quando nas faixas superiores, obtendo-se uma forma visualmente fäcil de interpretar.

Na carta gráfica foi mostrado, também, o valor obtido pelo município no indicador-resumo. 
5. Resultados e discussão 


\section{RESULTADOS E DiSCUSSÃO}

\subsection{SELEÇÃO E VALIDAÇÃO DE INDICADORES}

\section{Revisão das prioridades do Programa}

Os objetivos do PCT são de duas ordens. No campo individual, a redução do sofrimento dos doentes e dos danos que acompanham a doença - incapacidades, perda da condição laboral, marginalização social, mortes evitáveis que, em sua grande maioria, atingem pessoas na fase em que são esteio de famílias. No aspecto coletivo, a permanência de fontes de infecção faz com que o ciclo epidemiológico permaneça, perpetuando uma situação que há muito vem sendo considerada "um escândalo" ${ }^{21}$, onde uma doença para a qual há armas potentes como o diagnóstico, fácil na maioria das vezes, e o tratamento eficaz e barato, ainda faz tantas vítimas.

Dado que os casos de maior importância epidemiológica na transmissão são os pulmonares baciliferos e que o período de transmissibilidade se concentra entre o início dos sintomas e as primeiras semanas após a instituição de tratamento eficaz, é consensual para a Organização Mundial da Saúde ${ }^{31,67}$, o Ministério a Saúde ${ }^{45,46,83}$ e a Secretaria de Saúde do Estado de São Paulo ${ }^{83}$ que o sucesso de um programa de controle da doença está em descobrir precocemente e conduzir esses casos à cura.

Sendo as medidas de maior impacto no Programa, qualquer proposta de vigilância e monitoramento passa pela seleção de variáveis que possam auxiliar na percepção do desempenho no complexo busca-tratamento, principalmente dos casos baciliferos. $\mathrm{O}$ modelo lógico seguido foi baseado na seqüência cronológica de descoberta de casos, diagnóstico e tratamento, conforme se observa na Figura 1. 


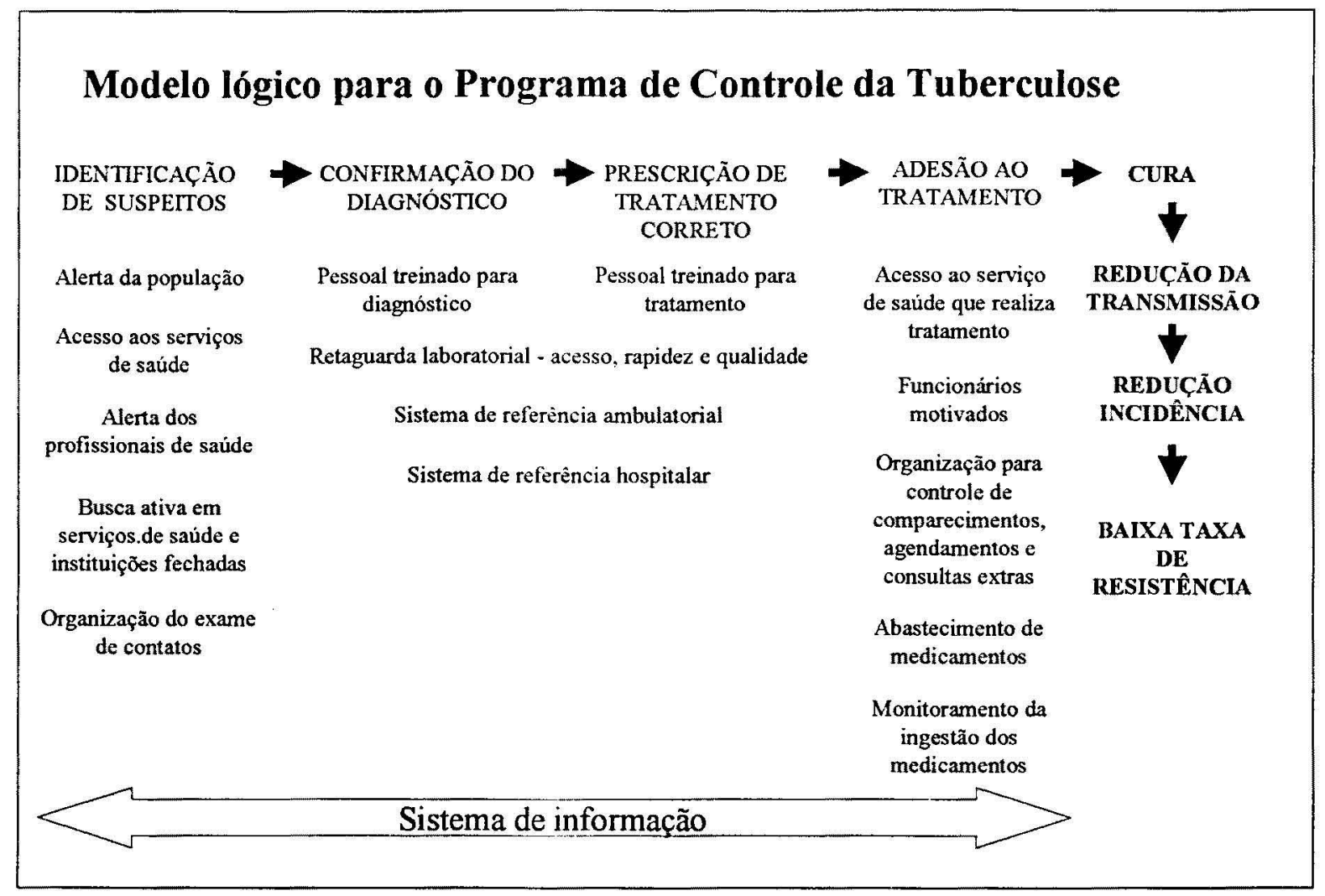

Figura 1. Modelo lógico para o Programa de CONTrole da Tuberculose.

Seguindo-se o fluxo dessas etapas, foram definidos três aspectos a serem avaliados:

- Intensidade da busca de casos

- Qualidade do diagnóstico

- Processo e resultados do tratamento

\subsubsection{Escolha das variáveis}

A literatura acerca das medidas de controle da tuberculose é ampla, sendo que há poucas controvérsias sobre seus principais aspectos. Neste trabalho, serão citadas apenas algumas, indispensáveis para a compreensão dos motivos para serem 
priorizadas algumas variáveis.

Dado que se deseja analisar o desempenho dos municípios de forma rotineira e reprodutível em intervalos pelo menos anuais, escolheram-se, para compor os indicadores, eventos suficientemente freqüentes para estarem presentes na maioria dos municípios envolvidos. Por este motivo, algumas variáveis importantes para avaliar o PCT em âmbito estadual ou nacional, passíveis de obtenção a partir das fichas de notificação, não são aplicáveis a todos os municípios - é o caso, por exemplo, da incidência de meningite tuberculosa em crianças com menos de 4 anos, indicador importante da ocorrência de transmissão recente e/ou baixa cobertura vacinal que, por se tratar de evento raro, fica inviabilizado em municípios de pequeno e médio porte. Outros exemplos: porcentagem de casos em que houve mudança de diagnóstico, após a introdução do tratamento para tuberculose; porcentagem de óbitos sem tratamento; porcentagem de falências; porcentagem de casos internados para elucidação diagnóstica. A mesma situação ocorre com subpopulações, que são importantes do ponto de vista epidemiológico e poderiam ser analisadas em separado. É o caso dos retratamentos, um grupo que desperta preocupação ${ }^{2}$ quanto ao risco de resistência medicamentosa e alta proporção de insucessos no tratamento, e dos doentes HIV-positivos, outro grupo bastante preocupante ${ }^{98}$. Todos estes itens tinham numeradores muito pequenos nos municípios de menor incidência, não sendo convenientes para esta análise.

Outros indicadores, como a proporção de contatos examinados, não foram testados devido à alta freqüência de registros em que faltavam essas informações.

Foram também excluídos os coeficientes de incidência, pelo fato de não 
dependerem da qualidade dos programas de controle municipais a curto e médio prazos.

A seguir, um breve arrazoado para a seleção inicial de variáveis que poderiam compor os indicadores.

\section{Busca de casos}

O principal indicador da intensidade da busca de casos, recomendado pela Organização Mundial da Saúde ${ }^{99}$ e pelo Ministério da Saúde ${ }^{46,53}$, é o número de sintomáticos respiratórios que foram identificados como tal e realizaram exame de baciloscopia de escarro. Medir esse indicador não é tarefa fácil num Estado que conta com grande número de serviços de saúde administrados por mais de 600 municípios, inúmeros laboratórios públicos e privados, que atendem a usuários provenientes de diferentes serviços de saúde, tanto ambulatoriais como hospitalares e de urgência.. Para suprir essa dificuldade, no Estado de São Paulo, houve a estruturação de um sistema de base laboratorial - o LAB-TB - que registra, além de outros dados, o número de sintomáticos examinados por baciloscopia de escarro. Mas esse sistema foi iniciado em outubro de 2002, o que impediu que fossem testados neste trabalho. Porém, alguns dados provenientes das notificações podem fornecer informações importantes quanto à descoberta dos casos.

Uma informação que retrata a qualidade da busca de casos é a demora até o início do tratamento. A precocidade do diagnóstico esbarra na semelhança dos sintomas com outras afecções respiratórias, na demora do paciente a procurar atenção médica por motivos vários, muitas vezes culturais ou de trabalho, quando não pelo acesso por vezes difícil aos serviços de saúde, na falta de conhecimento ou 
atenção dos profissionais de saúde para a suspeita diagnóstica.

O intervalo de tempo entre o início dos sintomas e as primeiras semanas de tratamento efetivo do doente bacilífero é aquele em que ocorre a maioria das transmissões da infecção tuberculosa ${ }^{8,57}$. Esse período compreende duas fases: a primeira, conhecida na literatura como primeira demora ou "demora do paciente" (patient's delay), corresponde ao tempo entre o início da tosse - na impossibilidade de se definir quando efetivamente o paciente se tornou bacilifero - e a procura de atenção médica. A segunda fase, desse momento até o início do tratamento, é chamada "demora médica" ou "demora do sistema de saúde" (doctor's delay, health care system's delay).

Embora tenham determinantes distintos, essas fases não são tão diferentes como o nome sugere. $\mathrm{O}$ tempo que o indivíduo, já com os sintomas da doença, leva para perceber sua condição de doente e se decidir a procurar um serviço de saúde não depende somente de características pessoais. Ele tem a ver com características psicosocio-culturais de valoração de seu estado de saúde, mas também com suas experiências anteriores e imagens dos próprios serviços de saúde em termos de acesso e resolubilidade. A "demora do paciente", então, não é de sua "responsabilidade" ${ }^{37}$, fruto somente de sua formação cultural ${ }^{93}$ ou condições de vida e de trabalho ${ }^{79}$, mas está intimamente relacionada à forma como o sistema de saúde está estruturado, desde a distância desses serviços, seus horários e regras de atendimento, até o acolhimento reservado aos usuários ${ }^{54,58}$.

Também a denominação demora médica pode levar à falsa impressão de ser simplesmente devida à falta de capacidade ou empenho desse profissional em 
formular o diagnóstico e prescrever o tratamento. Ao contrário, embora inclua esses possiveis fatores em sua composição, muito depende da forma como os serviços de saúde estão organizados ${ }^{18}$, do acesso à primeira consulta médica, a demora na suspeita da doença, disponibilidade de serviços auxiliares de diagnóstico (em especial recursos laboratoriais e de radiologia), tempo entre a colheita de exame e chegada do resultado ${ }^{8}$, definição de local responsável por instituir o tratamento, rotinas para agendamento ${ }^{71}$, etc.

Há controvérsias sobre o papel da precocidade da descoberta de casos na intensidade da transmissão da tuberculose ${ }^{46}$. Mesmo que o impacto não seja tão intenso quanto gostaríamos, isso não invalida que se postule que o PCT em um município seja tanto melhor quanto mais cedo consegue descobrir a doença. Afinal, do ponto de vista do paciente, é incontestavelmente melhor que esta seja descoberta antes de causar maiores danos.

Um dado disponivel nas notificações e que pretende medir diretamente a precocidade na descoberta de casos é o tempo decorrido entre os primeiros sintomas respiratórios e o início do tratamento. Informações sobre a demora, apesar de sua importância, não são coletadas pelo Sistema Nacional de Notificações de Agravos de Notificação Compulsória (SINAN) ${ }^{59}$ e só têm sido analisadas em estudos especiais ${ }^{10}$. Não consta da atual ficha de notificação a especificação da primeira e segunda demora, como havia nos trabalhos mencionados do NIVE-TB/FSP ${ }^{12}$, mas apenas a demora total.

O Ministério da Saúde recomenda, como ponto de corte para a suspeita de tuberculose, que seja considerado um "sintomático respiratório", para o qual se deve 
realizar pesquisa de tuberculose por baciloscopia de escarro, o indivíduo que apresenta tosse produtiva por mais de 3 semanas $^{46}$. Para o indicador de busca de casos, calculou-se a porcentagem de casos com demora até 8 semanas.

Outros dados presentes na ficha de notificação focalizam aspectos específicos do processo de busca de casos: a distribuição percentual dos doentes que são descobertos em ambulatórios ou em prontos-socorros e hospitais, e sua classificação em serviços públicos, privados ou universitários. Quanto à vinculação do serviço que descobriu o caso, não se considerou haver diferenças de valor - não é melhor ou pior que o caso seja descoberto em serviços públicos que nos particulares, já que o que se deseja é a descoberta precoce da tuberculose onde quer que o paciente procure atendimento.

Considerando o fato de que a participação dos hospitais e prontos-socorros na detecção dos casos de tuberculose tende a ser diretamente proporcional à gravidade dos casos, e que uma boa rede básica de saúde é a porta de entrada adequada para casos iniciais da doença, este indicador foi incluído, apesar das diferenças de estrutura de serviços e de recursos dos municípios. Quando a porta de entrada preferencial é um pronto-socorro, em geral, há maior dificuldade no encaminhamento dos casos. A variável testada foi a proporção dos casos descobertos em serviços ambulatoriais públicos, privados, filantrópicos e pelos médicos autônomos.

A forma de descoberta dos casos, na ficha de notificação, é informada segundo a forma de apresentação dos pacientes ao serviço de saúde que vai tratá-los, informada na ficha de notificação [anexo 1]. 
Na primeira alternativa, a suspeita se faz no próprio serviço de saúde onde é realizado o atendimento, como resultado do atendimento de sintomáticos respiratórios (busca passiva); na segunda, a doença é descoberta quando o doente se apresenta por outros motivos, representando a intensidade de busca ativa no próprio serviço de saúde, em pessoas que lá estavam não pelas suas queixas respiratórias mas por outras causas; uma outra forma é aquela em que o caso é encaminhado por outros serviços, com suspeita ou mesmo diagnóstico firmado, ou seja, o paciente passou pelo menos por mais um serviço de saúde antes de iniciar o tratamento; ou finalmente se a descoberta se deu pelo controle de contatos, refletindo a intensidade dessa atividade.

Inicialmente, foram cogitadas duas formas para abordagem deste item:

a) na primeira, mais estrita, seria considerada a porcentagem de casos descobertos por busca ativa: a soma dos doentes descobertos ao procurarem espontaneamente o serviço de saúde por motivos outros que não os sintomas respiratórios, mais aqueles cuja tuberculose foi diagnosticada por busca de contatos.

b) Numa fórmula mais ampla, seriam incluídos, além dos anteriores, os casos que procuraram espontaneamente os serviços de saúde devido a sintomas respiratórios, ficando excluídos somente os que chegaram encaminhados de outros locais e uma minoria descoberta por atestados de óbito.

Para compor esta variável, optou-se pela segunda fórmula, uma vez que nos municípios menores o número de casos descobertos por busca ativa pode ser pouco significativo. Para esta decisão, também contribuiu a constatação de que a descoberta passiva de sintomáticos respiratórios que procuram espontaneamente os serviços de 
saúde é considerada a principal estratégia pela organização Mundial da Saúde ${ }^{12,88}$. Autores clássicos no campo da tuberculose $e^{77,88}$ já assinalavam que, como a tuberculose provoca sintomas que quase sempre levam o doente a procurar assistência médica, uma boa estratégia é aproveitar essa oportunidade para se pesquisar a doença pela baciloscopia de escarro. É a chamada busca passiva de casos, baseada no alerta dos profissionais de saúde. Estudos promovidos pelo Banco Mundial apontaram o complexo busca passiva de sintomáticos/diagnóstico por baciloscopia de escarro/tratamento dos baciliferos como uma das intervenções de melhor relação custo/beneficio na área da saúde, comparável à vacinação contra o sarampo e a terapia de reidratação oral ${ }^{92,50,51}$.

Outro dado que consta no sistema de informação e indica minimamente uma preocupação com a descoberta da doença é o exame de contatos domiciliares. Faz parte das recomendações do Ministério da Saúde ${ }^{41,44}$ a pesquisa de casos nesse grupo que, como se sabe, é o maior alvo de contágio". Escolheu-se a variável "registro do número de contatos" porque o efetivo exame destes, em geral, ainda não foi realizado no momento em que a ficha de notificação é preenchida e não há instrumento para coleta posterior desses dados.

Outros dados, medidas indiretas da descoberta tardia, também foram testados. Um sinal de gravidade por ocasião da descoberta é a proporção de casos cavitários nas formas clínicas pulmonares em adultos. Sendo a tuberculose, em geral, de evolução crônica ou subaguda, é de se esperar que, quanto maior o número de casos cavitários, mais avançado o estágio da doença por ocasião da descoberta. $\mathrm{O}$ exame radiológico, por outro lado, é realizado no Estado de SP em mais de $90 \%$ dos 
casos pulmonares. A porcentagem de casos cavitários entre os pulmonares adultos foi por este motivo incluída no rol dos indicadores de busca de casos.

Da mesma forma que o anterior, a necessidade de internação foi considerada um sinal de retardo no diagnóstico. A proporção de pacientes internados, ao lado de seu significado de gravidade da doença no momento da descoberta, evidencia também falha na organização do Programa, já que se recomenda evitar a hospitalização dos pacientes, diminuindo inclusive a transmissão institucional da doença. A internação poderia ser um marcador do avanço da doença por ocasião do diagnóstico.

TABELA 1. VARLÁVEIS TESTADAS PARA INTENSIDADE DA BUSCA DE CASOS

\begin{tabular}{|l|l|l|l|}
\hline Código & Variável & Numerador & Denominador \\
\hline B1 & Demora até início do tratamento & $\begin{array}{l}\text { Casos novos cujo tempo decorrido } \\
\text { entre o início dos sintomas o o } \\
\text { início do tratamento foi } \leq 8 \\
\text { semanas }\end{array}$ & Casos novos \\
\hline B2 & $\begin{array}{l}\text { Procura de sintomáticos } \\
\text { respiratórios }\end{array}$ & $\begin{array}{l}\text { Casos novos pulmonares - } \\
\text { Chegada ao local de tratamento } \\
\text { espontaneamente ou por } \\
\text { convocação de contatos }\end{array}$ & Casos novos pulmonares \\
\hline B3 & Descoberta ambulatorial & $\begin{array}{l}\text { Casos novos pulmonares } \\
\text { descobertos em atendimento } \\
\text { ambulatorial, incluindo médicos } \\
\text { particulares }\end{array}$ & Casos novos pulmonares \\
\hline B4 & Casos pulmonares não cavitários & $\begin{array}{l}\text { Casos novos pulmonares } \\
\text { Exame radiológico sem imagem } \\
\text { radiológica cavitária }\end{array}$ & Casos novos pulmonares \\
\hline B5 & $\begin{array}{l}\text { Tratamento ambulatorial } \\
\text { exclusivo }\end{array}$ & $\begin{array}{l}\text { Casos novos pulmonares } \\
\text { Inexistência de registro de } \\
\text { internação }\end{array}$ & $\begin{array}{l}\text { Total de casos novos com } \\
\text { informação sobre o número de } \\
\text { contatos }\end{array}$ \\
\hline
\end{tabular}

* todas as variáveis estão na forma de proporção de casos que satisfazem a uma determinada condição

Ainda como sinal de retardo no diagnóstico, foram testadas duas variáveis relacionadas ao desfecho do caso: a taxa de sobrevida e a proporção de casos em que 
não ocorreu óbito antes de completar 1 mês de tratamento. Esta última, embora mais específica em relação ao significado - os óbitos mais tardios provavelmente têm forte relação com a qualidade do tratamento e não somente falhas no diagnóstico tem a desvantagem de ser uma ocorrência mais rara, dificultando a interpretação nos municípios menores. Vale lembrar que, para que o indicador tenha sentido positivo, é preciso lançar mão de estratagemas semânticos. Assim sendo, chamou-se taxa de sobrevida, que é o complemento da taxa de letalidade, e assim por diante.

Em resumo, foram testadas as 6 variáveis que constam na tabela 1, na forma de porcentagem de casos que satisfazem aos critérios mencionados, para mensurar a intensidade da busca de casos.

\section{Qualidade do diagnóstico}

O segundo passo no processo de descoberta dos casos, passível de ser analisado a partir de informações das fichas de notificação de tuberculose, é a qualidade do diagnóstico. Para isso, pode-se partir de dados sobre os critérios de confirmação dos casos notificados. Apesar do baixo custo e pouca complexidade dos exames laboratoriais necessários para a maioria dos casos de importância epidemiológica, a questão da organização dos serviços de apoio ao diagnóstico retarda a confirmação dos casos, sendo que a prática médica, respaldada pela cultura do aparelho formador nas universidades, não privilegia a confirmação bacteriológica dos $\operatorname{casos}^{40}$.

Segundo conclusões do I Consenso Brasileiro de Tuberculose ${ }^{42}$, realizado em 1997, "é preocupante a taxa de baciloscopias não realizadas" e a retirada da necessidade de existência de baciloscopia positiva, presente nos manuais de normas 
brasileiros anteriores a 1995, abrindo a possibilidade de diagnóstico firmado com base em critérios clínico-epidemiológicos e em exames complementares, "traz a perspectiva de diagnóstico e tratamento mais precoces, porém traz também a preocupação com a queda de sua precisão".

Sabe-se que a sensibilidade da baciloscopia de escarro para diagnóstico da tuberculose deixa a desejar, mesmo realizando-se repetidos exames. Recomenda-se realizar duas baciloscopias de escarro para os sintomáticos respiratórios, uma vez que a terceira pouco acrescentaria ${ }^{46}$. Para os casos em que as duas amostras forem negativas, a investigação diagnóstica deve prever a realização de culturas para micobactérias e, se possível, outros métodos como lavado bronco-alveolar ou indução de escarro.

Sempre que as condições clínicas o permitam, somente após esgotarem-se os meios de diagnóstico disponíveis ${ }^{42}$ e, se possivel, após tentar um tratamento com antibióticos que não sejam parte do arsenal terapêutico da tuberculose deve ser introduzido um tratamento específico para casos não confirmados com imagens radiológicas compatíveis ${ }^{38}$.

A realização de baciloscopia de escarro condição consensual de qualidade do diagnóstico da tuberculose pulmonar, mesmo que o exame radiológico seja altamente sugestivo $^{94}$. Os suspeitos, na imensa maioria, têm tosse e conseguem produzir amostras de escarro a serem examinadas. $O$ indicador escolhido foi a proporção de casos pulmonares acima de 14 anos em que foi realizada a baciloscopia de escarro.

Para os casos pulmonares cuja baciloscopia resulta negativa em duas 
amostras diferentes, é recomendado pelo Ministério da Saúde a realização de cultura $^{46}$, uma vez que esses casos em geral não são clinicamente tão graves e podem aguardar um diagnóstico mais consistente. Sabe-se que o exame radiológico por si só não confirma a tuberculose, havendo um risco nada desprezível ${ }^{95}$ de se iniciar um tratamento que é longo e penoso, com medicamentos cujos efeitos tóxicos não são raros, para pacientes que na realidade não têm tuberculose. Além disso, como o exame radiológico tem baixa especificidade, iniciar tratamento específico sem tentar a comprovação etiológica aumenta o risco de perda de tempo em relação à real enfermidade do doente.

A proporção de casos em que, sendo a baciloscopia negativa, foi realizada a cultura, foi outro item incluído entre as variáveis testadas como sinalizadoras de bom controle da tuberculose.

A qualidade do diagnóstico pode ser medida pela proporção de casos em que este foi confirmado. Como critério de confirmação dos casos pulmonares, utilizou-se a obtenção de resultado bacteriológico positivo por baciloscopia e/ou cultura. Para os casos extrapulmonares, acrescentou-se o resultado de exame histopatológico compativel, dado que são com frequeência paucibacilares e o achado de granulomas no exame histopatológico, embora com especificidade limitada, é por vezes a opção disponível para aumentar a certeza do diagnóstico ${ }^{43}$.

$\mathrm{Na}$ tabela 2 vê-se a relação de variáveis testadas para qualidade do diagnóstico. 
TABELA 2 . VARIÁVEIS TESTADAS PARA QUALIDADE DO DIAGNÓSTICO

\begin{tabular}{|c|c|c|c|}
\hline Código & Variável & Numerador & Denominador \\
\hline D1 & $\begin{array}{l}\text { Confirmação bacteriológica dos } \\
\text { casos pulmonares }\end{array}$ & $\begin{array}{l}\text { Total de casos pulmonares } \\
\text { Baciloscopia e/ou cultura positiva } \\
\text { no diagnóstico }\end{array}$ & Total de casos pulmonares \\
\hline D2 & Realização de baciloscopia & $\begin{array}{l}\text { Casos pulmonares } \geq 15 \text { anos } \\
\text { Registro de resultado positivo ou } \\
\text { negativo de baciloscopia de } \\
\text { escarro para diagnóstico }\end{array}$ & Casos pulmonares $\geq 15$ anos \\
\hline D3 & Solicitação de teste anti-HIV & $\begin{array}{l}\text { Casos novos com registro de } \\
\text { solicitação de teste anti-HIV } \\
\text { (positivo, negativo ou em } \\
\text { andamento) }\end{array}$ & Casos novos \\
\hline D3 & Utilização da cultura & $\begin{array}{l}\text { Casos novos pulmonares com } \\
\text { baciloscopia negativa e resultado } \\
\text { de cultura (positiva ou negativa) } \\
\text { para diagnóstico }\end{array}$ & $\begin{array}{l}\text { Casos novos pulmonares } \\
\text { com baciloscopia negativa }\end{array}$ \\
\hline D4 & $\begin{array}{l}\text { Confirmação dos casos novos } \\
\text { pulmonares }\end{array}$ & $\begin{array}{l}\text { Casos novos pulmonares com } \\
\text { baciloscopia e/ou cultura positiva } \\
\text { no diagnóstico }\end{array}$ & Casos novos pulmonares \\
\hline D5 & $\begin{array}{l}\text { Confirmação dos casos novos } \\
\text { extrapulmonares }\end{array}$ & $\begin{array}{l}\text { Casos novos forma clínica } \\
\text { extrapulmonar com baciloscopia } \\
\text { e/ou cultura positiva, ou exame } \\
\text { histopatológico sugestivo de } \\
\text { tuberculose no diagnóstico }\end{array}$ & $\begin{array}{l}\text { Casos novos forma clínica } \\
\text { extrapulmonar }\end{array}$ \\
\hline
\end{tabular}

*todas as variáveis estão na forma de proporção de casos que satisfazem a uma determinada condição

\section{Tratamento}

De nada adianta descobrir precocemente os casos, é óbvio, se os mesmos não forem conduzidos à cura. Esta vem sendo a grande preocupação para o controle da tuberculose. A cura da doença depende de muitos fatores: o tratamento, apesar de altamente eficaz, necessita de um mínimo de 6 meses para alcançar a cura e evitar as recidivas. Isso demanda a adesão dos pacientes, problema este já antevisto mas pouco valorizado quando da descoberta dos primeiros medicamentos antituberculose $\mathrm{e}^{27,28,30}$.

Os dados sobre resultados de tratamento são registrados mensalmente no acompanhamento do sistema EPI-TB. Outros dados que puderam ser usados são a 
observância do esquema de tratamento padronizado (proporção de casos novos com esquema inicial de RHZ, proporção de curas aos 5 meses ou menos, curas em mais de 7 meses) ${ }^{46}$, a porcentagem de retratamentos ${ }^{34}$ e o controle bacteriológico da resposta ao tratamento ${ }^{40,35}$, negativação do exame baciloscópico dos casos inicialmente bacilíferos e número de baciloscopias de controle.

Um dado que, infelizmente, não foi possível utilizar foi a porcentagem de casos resistentes às drogas. Apesar de relativamente raros, estes casos têm extrema importância, mas o registro dos resultados só recentemente vem sendo feito de maneira sistemática, num fluxo paralelo de informações de laboratórioi.

A realização do teste para HIV também pode indicar qualidade do tratamento. Desde 1998 que, em São Paulo, é recomendação realizar sorologia para HIV para todos os pacientes de tuberculose, dada a freqüente concomitância dos dois agravos e a importância de saber se o doente de tuberculose é também portador desse vírus, caso em que pode necessitar de outros cuidados e medicamentos, além da investigação adicional dos contatos quanto à infecção pelo HIV. Em 2002, foi formalizada a indicação nacional de oferecimento do teste para HIV a todos os pacientes de tuberculose ${ }^{46}$. A solicitação de sorologia para HIV foi incluída entre as variáveis indicativas de qualidade do tratamento, e não do diagnóstico. Explica-se: este é um exame que costuma ser solicitado pelo médico responsável pela condução do tratamento, raramente necessário para esclarecimento do diagnóstico.

\footnotetext{
i Secretaria de Estado da Saúde de São Paulo / Centro de Vigilância Epidemiológica / Divisão de Tuberculose informação pessoal
} 
Quanto à organização do Programa, a administração supervisionada dos medicamentos, sob as vistas de um profissional de saúde, vem sendo fortemente recomendada pelos organismos internacionais e nacionais. Há resultados contraditórios quanto à efetividade desta estratégia. Uma revisão sistemática publicada em $1988^{16}$ concluiu pela sua recomendação, especialmente quando acompanhada de incentivos e facilitadores. Resultado oposto foi obtido em outra revisão sistemática, realizada pelo Cochrane Infectious Disease Group em $2002^{97}$. Também no Brasil, Dalcolmo ${ }^{20}$ não encontrou diferença significativa entre supervisionar ou não a ingestão dos medicamentos. Mas é indiscutível que, seja por mérito da ingestão supervisionada propriamente dita, seja pelo fato de motivar uma reorganização do atendimento para melhor e uma aproximação dos profissionais de saúde com o paciente - e isto tem sido bastante referido em encontros e reuniões de avaliação do PCT em São Paulo - a importância desta proposta justifica a inclusão do tratamento supervisionado como um dos itens testados neste estudo.

O PCT também preconiza que haja descentralização, facilitando o acesso ao diagnóstico e tratamento próximo à residência do doente ${ }^{46}$. A taxa de evasão de doentes para tratamento em outros municípios, bem como a taxa de invasão, que representa a carga adicional de doentes tratados nesse município e que residem em outro local, podem também estar relacionadas com a qualidade do PCT. Para a taxa de invasão, outros fatores devem contribuir como variáveis de confusão, como o porte dos municípios e sua localização. Tendo em vista que a grande maioria dos casos de tuberculose não requer equipamentos especiais ou outros recursos sofisticados, testou-se a variável taxa de auto-suficiência, complemento da taxa de evasão: a proporção de doentes que residem no município e ali foram atendidos. Foi 
também testada a menção do número de contatos existentes, como indicativo do cuidado que os serviços que tratam devem ter com os que coabitam com os pacientes ${ }^{46}$. A tabela 3 mostra a forma de construção das variáveis testadas para qualidade do tratamento.

TABEla 3. VARIÁveIs testadas Para Qualidade Do Tratamento

\begin{tabular}{|c|c|c|c|}
\hline Código & Variável & Numerador & Denominador \\
\hline $\mathrm{T} 1$ & Taxa de curas (total) & Casos encerrados por alta-cura & Total de casos \\
\hline $\mathrm{T} 2$ & Controle bacterioscópico & $\begin{array}{l}\text { Casos novos pulmonares } \\
\text { baciliferos, pelo menos duas } \\
\text { baciloscopias de controle }\end{array}$ & $\begin{array}{l}\text { Casos novos pulmonares } \\
\text { baciliferos }\end{array}$ \\
\hline T3 & Negativação da baciloscopia & $\begin{array}{l}\text { Casos novos pulmonares } \\
\text { baciliferos, pelo menos uma } \\
\text { baciloscopia de controle negativa }\end{array}$ & $\begin{array}{l}\text { Casos novos pulmonares } \\
\text { baciliferos }\end{array}$ \\
\hline $\mathrm{T} 4$ & Razão de adesão & Casos novos encerrados por cura & $\begin{array}{l}\text { Casos novos encerrados por } \\
\text { cura ou abandono }\end{array}$ \\
\hline T5 & Uso do esquema padronizado & $\begin{array}{l}\text { Casos novos com esquema inicial } \\
\text { de tratamento } \mathrm{RHZ}\end{array}$ & Casos novos \\
\hline T6 & Tratamento supervisionado & $\begin{array}{l}\text { Registro de tratamento } \\
\text { supervisionado }\end{array}$ & Total de casos \\
\hline $\mathrm{T} 7$ & Percentual de casos novos & $\begin{array}{l}\text { Casos novos (sem tratamento } \\
\text { anterior nos últimos } 5 \text { anos) }\end{array}$ & Total de casos \\
\hline $\mathrm{T} 8$ & $\begin{array}{l}\text { Taxa de cura dos casos } \\
\text { encerrados }\end{array}$ & Casos novos com alta por cura & $\begin{array}{l}\text { Casos novos com informação } \\
\text { de encerramento }\end{array}$ \\
\hline T9 & Tempo de tratamento suficiente & $\begin{array}{l}\text { Casos novos com alta-cura em } \\
\text { mais de } 165 \text { dias }\end{array}$ & $\begin{array}{l}\text { Casos novos com alta por } \\
\text { cura }\end{array}$ \\
\hline $\mathrm{T} 10$ & $\begin{array}{l}\text { Tempo de tratamento não } \\
\text { excessivo }\end{array}$ & $\begin{array}{l}\text { Casos novos com alta-cura em } \\
\text { tempo menor que } 210 \text { dias }\end{array}$ & $\begin{array}{l}\text { Casos novos com alta por } \\
\text { cura }\end{array}$ \\
\hline T11 & Percentual de encerramento & $\begin{array}{l}\text { Casos novos com informação de } \\
\text { encerramento }\end{array}$ & Total de casos novos \\
\hline $\mathrm{T} 12$ & Taxa de auto-suficiência & Tratados no próprio município & Total de casos residentes \\
\hline
\end{tabular}

* todas as variáveis estão na forma de proporção de casos que satisfazem a uma determinada condição

\subsubsection{Avaliação da confiabilidade e construção de indicador sintético}

\section{Indicador parcial de busca de casos (ITB-B)}

Quando se consideraram os dados de busca de casos por município de 
residência, o melhor valor de Alpha de Cronbach foi obtido pela combinação dos itens "Demora entre os primeiros sintomas e o inicio do tratamento até 8 semanas" $\mathrm{e}$ "Descoberta por procura espontânea ou controle de contatos", sendo obtido um Alpha de .4480 , alpha padronizado de .4693 . As demais variáveis testadas não se adequaram. A computação dos dados por município de atendimento revelou resultados semelhantes: Alpha .4833 e .5213 , respectivamente (Tabela 4).

TABela 4. Variáveis incluidas e respectivo AlPHa de Cronbach PaRa MEdida de desempenho de UM CONJUNTO DE MUNICIPIOS PAULISTAS NA DE BUSCA DE CASOS DA TUBERCULOSE EM 2002.

\begin{tabular}{|c|c|c|c|c|}
\hline \multirow[t]{2}{*}{ INDICADOR } & \multirow[t]{2}{*}{ VARIÁVEIS } & \multirow[t]{2}{*}{ CRITÉRIO } & \multicolumn{2}{|c|}{ ALPHA DE CRONBACH } \\
\hline & & & Simples & Padronizado \\
\hline ITB-B & $\begin{array}{l}\text { B1 - Demora sintomas/tratamento } \leq 8 \\
\text { semanas }\end{array}$ & $\begin{array}{l}\text { Município de } \\
\text { residência }\end{array}$ & .4480 & .4693 \\
\hline Busca de casos & $\begin{array}{l}\text { B2 - Procura de Sintomáticos Respiratórios } \\
\text { (busca ativa ou na demanda de sintomáticos } \\
\text { respiratórios) }\end{array}$ & $\begin{array}{l}\text { Municipio de } \\
\text { atendimento }\end{array}$ & .4833 & .5213 \\
\hline
\end{tabular}

\section{Indicador parcial de qualidade do diagnóstico (ITB-D)}

Entre os itens referentes a diagnóstico, foram compativeis "Realização de baciloscopia para casos pulmonares adultos" e a "Taxa de confirmação

\section{bacteriológica total'.}

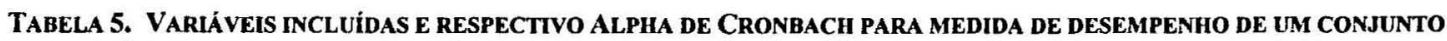
DE MUNICÍPIOS PAULISTAS NO DIAGNÓSTICO DA TUBERCULOSE EM 2002.

\begin{tabular}{|l|l|l|l|l|}
\hline \multirow{2}{*}{ INDICADOR } & VARIÁVEIS & \multirow{2}{*}{ CRITÉRIO } & \multicolumn{2}{|l|}{ ALPHA DE CRONBACH } \\
\cline { 3 - 5 } & & D1 - Confirmação bacteriológica total & Simples & Padronizado \\
\hline ITB-D & $\begin{array}{l}\text { D2 - Realização de baciloscopia para } \\
\text { Diagnóstico }\end{array}$ & diagnóstico dos casos pulmonares de & .6709 & .6916 \\
\cline { 3 - 5 } & $\geq 15$ anos & $\begin{array}{l}\text { Município de } \\
\text { atendimento }\end{array}$ & .6945 & .7204 \\
\hline
\end{tabular}


Os valores de Alpha simples e padronizado obtidos para dados segundo local de residência foram, respectivamente, .6709 e .6916 e, segundo município de atendimento, .6945 e .7204, como se vê na Tabela 5 .

\section{Indicador parcial de qualidade do tratamento (ITB-T)}

Para qualidade do tratamento, foram compatíveis: "Taxa de curas (total)", "Realização de pelo menos 2 baciloscopias de controle", "Negativação da baciloscopia dos casos baciliferos" e "Realização de teste para HIV". Os Alphas simples e padronizado por local de residência foram respectivamente .5920 e $.6107 \mathrm{e}$, por local de atendimento, 5951 e 5923 (Tabela 6).

TABEla 6. VARIÁveis INCLUÍDAS E RESPECTIVO ALPHA DE CRONBACH PARA MEDIDA DE DESEMPENHO DE UM CONJUNTO DE MUNICIPIOS PAULISTAS NO TRATAMENTO DA TUBERCULOSE. EM 2002

\begin{tabular}{|c|c|c|c|c|}
\hline \multirow[t]{2}{*}{ INDICADOR } & \multirow[t]{2}{*}{ VARIÁVEIS } & \multirow[t]{2}{*}{ CRITÉRIO } & \multicolumn{2}{|c|}{ ALPHA DE CRONBACH } \\
\hline & & & Simples & Padronizado \\
\hline ITB-T & $\begin{array}{l}\text { T1 - Taxa de cura (total de casos) } \\
\text { T2 - Controle baciloscópico do tratamento } \\
\text { (2 ou mais baciloscopias) }\end{array}$ & $\begin{array}{l}\text { Municipio de } \\
\text { residência }\end{array}$ & .5920 & .6107 \\
\hline Tratamento & $\begin{array}{l}\text { T3 - Negativação da baciloscopia } \\
\text { T4 - Realização de teste para HIV }\end{array}$ & $\begin{array}{l}\text { Municipio de } \\
\text { atendimento }\end{array}$ & .5951 & .5923 \\
\hline
\end{tabular}

Nos anexos 3 a 8 são mostrados os resultados, tal como se apresentam nos relatórios estatísticos emitidos para estas estatísticas.

\section{Indicador sintético comparativo (ITB)}

Para compor o indicador escalar ITB, a melhor combinação foi a que consta da tabela 7, sendo admitidos 6 itens. Assim, os municípios podem ser colocados em ordem de desempenho. Vale lembrar, novamente, que estas são posições relativas 
dos municípios, não possibilitando nenhum julgamento de valor absoluto sobre a qualidade do programa nos municípios.

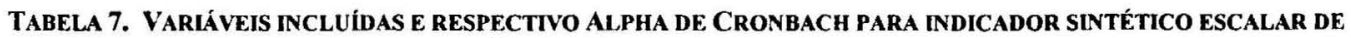
DESEMPENHO NAS ATIVIDADES DE DIAGNÓSTICO E TRATAMENTO DO PROGRAMA DE CONTROLE DA TUBERCULOSE, 57 MUNICIPIOS PAULISTAS SELECIONADOS

\begin{tabular}{|c|c|c|c|c|}
\hline INDICADOR & VARIÁVEIS & CRITÉRIO & \multicolumn{2}{|c|}{$\begin{array}{l}\text { ALPHA DE } \\
\text { CRONBACH }\end{array}$} \\
\hline \multirow[t]{2}{*}{$\begin{array}{c}\text { ITB } \\
\text { INDICADOR } \\
\text { SINTÉTICO } \\
\text { COMPARATIVO } \\
\text { DE DESEMPENHO } \\
\text { DOS MUNICÍPIOS } \\
\text { NOPCT }\end{array}$} & \multirow{2}{*}{$\begin{array}{l}\text { D1 - Confirmação bacteriológica dos casos } \\
\text { pulmonares } \\
\text { D3 - Realização de baciloscopia para } \\
\text { diagnóstico dos casos pulmonares } \\
\text { Z15 anos } \\
\text { T2 - Controle baciloscópico do tratamento (2 } \\
\text { ou mais baciloscopias de controle) } \\
\text { T3 - Negativação da baciloscopia } \\
\text { T4 - Realização de teste para HIV } \\
\text { T5 - Razão de adesão }\end{array}$} & $\begin{array}{l}\text { Municipio } \\
\text { de } \\
\text { residência }\end{array}$ & .6392 & .6735 \\
\hline & & $\begin{array}{l}\text { Município } \\
\text { de } \\
\text { atendimento }\end{array}$ & .6756 & .7198 \\
\hline
\end{tabular}

Como se vê, foi possível incluir itens referentes a qualidade de diagnóstico e de tratamento. Os itens correspondentes à avaliação da busca de casos não foram aceitos por terem correlações negativas com alguma outra variável.

Nas tabelas 8 e 9 são mostrados os resultados do Alpha de Cronbach para o indicador sintético de desempenho no PCT para os dados computados, respectivamente, segundo município de residência e de atendimento.

$\mathrm{Na}$ avaliação por município de residência, vê-se que o item "negativação da baciloscopia" foi responsável pela maior variação: sua retirada levaria à variância de 1350.4534. Mas é o que tem maior correlação item-total e o que mais falta faria se fosse eliminado, levando a um alpha de .5222 .

Já a razão de adesão não acrescenta quase nada à confiabilidade do indicador, pois o Alpha sem esta variável passaria de .6392 para .6387. Sua 
correlação com os demais itens é relativamente baixa. Sendo ela o único indicador de resultado, pode-se levantar a hipótese de que esteja acrescentando algum aspecto novo ao indicador sintético. De fato, os outros itens de qualidade do tratamento se referem mais ao aspecto da conduta clínica (acompanhamento e negativação bacteriológica, teste para HIV), e a razão de adesão incorpora o fator de conseguir efetivamente que o doente não abandone o tratamento. Esta característica justifica sua inclusão, até porque não há nenhum ônus a mais na obtenção deste item.

TABELA 8. ALPHA DE CRONBACH PARA INDICADOR SINTÉTICO DE DESEMPENHO (ITB) DADOS COMPUTADOS SEGUNDO MUNICIPIO DE RESIDÊNCLA

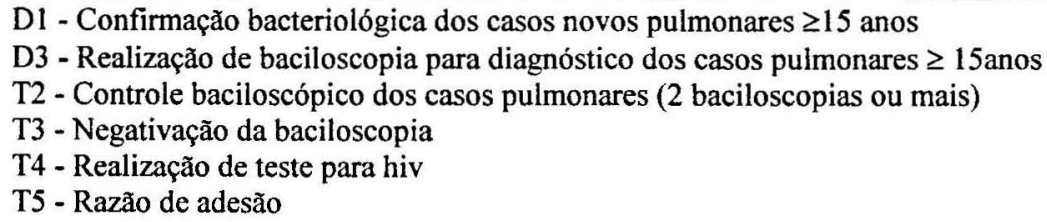

Squared

Multiple

Correlation

.1784

.4031

.1595

.3520

.3465

.3378
Alpha if

Item

Deleted

.6125

.5222

.6387

.5918

.6107

.5554

Reliability Coefficients 6 items

$$
\text { Alpha }=.6392 \quad \text { Standardized item alpha }=.6735
$$


TABELA 9. ALPHA DE CRONBACH PARA INDICADOR SINTÉTICO DE DESEMPENHO - DADOS COMPUTADOS SEGUNDO MUNICIPIO DE ATENDIMENTO

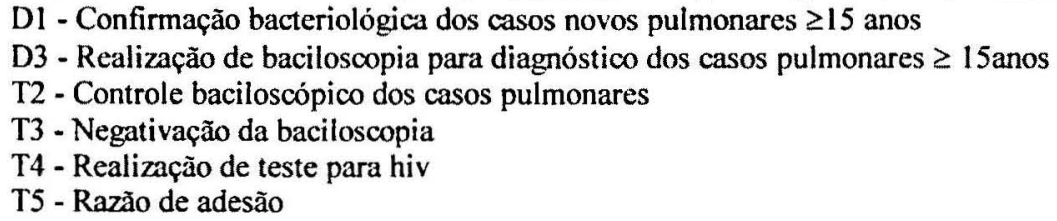

Item-total Statistics Scale Mean if Item Deleted

D1 $\quad 369.4316$

346.3930

320.0123

300.1158

.6294

12.5939

\begin{tabular}{|c|c|c|c|}
\hline Scale & Corrected & Squared & Alpha if \\
\hline Variance if & Item- Total & Multiple & Item \\
\hline Item Deleted & Correlation & Correlation & Deleted \\
\hline 2583.1340 & .5716 & .4268 & .5706 \\
\hline 1628.1157 & .6221 & .4726 & .5815 \\
\hline 3258.0754 & .3725 & .3782 & .6479 \\
\hline 3667.7278 & .3195 & .2152 & .6743 \\
\hline 3108.2588 & .3290 & .2829 & .6587 \\
\hline 3334.0302 & .5411 & .4326 & .6299 \\
\hline
\end{tabular}

\subsubsection{Discussão}

\section{Validação dos indicadores}

Um bom conjunto de variáveis, que avalia bem o atributo desejado, deve resultar em um Alpha de Cronbach igual ou maior que $0.70^{66}$. Em situações onde o fenômeno é de dificil mensuração, entretanto, pode-se admitir valores menores, desde que fique clara e seja levada em conta essa limitação ${ }^{72}$. 
Tendo em vista que o sistema de notificação de doenças não é, e nem se espera que seja, um instrumento de precisão, poder avaliar com uma abrangência de cerca de $60 \%$, a qualidade do tratamento e $70 \%$ a do diagnóstico é, por si só, um grande ganho. Indiretamente, pode-se afirmar que o sistema de informação consegue determinar, com razoável grau de confiabilidade, a qualidade do desempenho dos municípios envolvidos nas ações de controle da tuberculose, quanto aos indicadores de diagnóstico e tratamento.

No caso do sistema em questão, é preciso lembrar os dados são coletados na rotina de um número muito grande de serviços de saúde, com graus variados de competência e disponibilidade para a tarefa de registro de dados. Numa pesquisa experimental, os pesquisadores costumam ser escolhidos e treinados especialmente para isso e a qualidade dos dados é cuidadosamente revisada. No caso da vigilância epidemiológica e, em especial, no atual contexto do SUS, a responsabilidade pela manutenção da qualidade dos dados é extremamente diluída e depende da adesão e disponibilidade de centenas ou milhares de pessoas. Neste trabalho havia notificações de 202 diferentes serviços de saúde dos 57 municípios. Além dos profissionais desses serviços, participam do fluxo de informação as equipes municipais e regionais de vigilância, além de outros serviços e equipes que, embora não pertençam a esses municípios, atenderam seus pacientes. Nesta situação, um Alpha de $60 \%$ parece bastante aceitável.

Já para a qualidade da busca de casos, ainda é preciso melhorar muito. Talvez porque a descoberta dos casos se dê em uma rede muito mais ampla do que sua confirmação e tratamento, ou pelo fato de serem dados menos trabalhados na 
rotina, a estatística mostra que somente cerca de $50 \%$ do problema é abrangido pelos indicadores, ou seja, uma confiabilidade "pela metade".

É interessante constatar que foi possivel a agregação de dois momentos do modelo lógico do PCT em um indicador único de diagnóstico/tratamento. Isso leva à hipótese de que essas atividades sejam, de alguma forma, interligadas - os municípios que têm um bom programa de controle conseguem realizar procedimentos que levam ao diagnóstico correto e conduzir os doentes até a cura. Isto fala a favor de que os responsáveis pela coordenação do PCT nesses municípios conseguem de alguma forma integrar as atividades de diagnóstico e tratamento.

Pelo mesmo raciocínio, é provável que, mesmo quando existe boa qualidade nessas atividades, a descoberta de casos - ou a informação sobre esse tópico - deixe a desejar. Mas é preciso reforçar que, embora essa etapa seja relacionada a muitos fatores externos aos serviços de saúde propriamente ditos - entre eles a consciência da população sobre o significado dos sintomas, sua disposição e possibilidade de procurar atenção médica - os resultados do programa têm muito a ver com um melhor acesso aos serviços. Captar mais precocemente os casos também é atribuição de um bom PCT e, como tal, precisa ser incorporada às preocupações de quem o conduz.

No geral, o Alpha de Cronbach, quando os dados foram obtidos por município de atendimento, foi superior àquele proveniente dos cálculos segundo município de residência. Esse fato não surpreende, uma vez que o registro e acompanhamento dos pacientes que se tratam no município estão evidentemente sob sua responsabilidade. Já aqueles que, embora residindo no município, são atendidos 
fora dele, muitas vezes escapam do controle e podem até ser desconhecidos pelo município de origem. Além disso, o sistema EPI-TB prevê o registro do caso no local de atendimento, ou seja, o local tem o domínio sobre o banco de dados dos casos atendidos por ele. Se o paciente é atendido fora do município de residência, o município toma conhecimento do caso ao receber mensalmente o banco de dados segundo local de residência, somente para consulta.

Num estado da dimensão de São Paulo, a magnitude do número de pacientes dificulta o controle e manejo de informações. Este tópico vem sendo objeto de atenção, até porque um dos princípios do SUS é a responsabilidade do município pela saúde dos seus munícipes. Quanto ao Alpha para tratamento, destaque-se que a combinação de itens validados inclui a taxa de cura em casos com registro de encerramento - não a taxa de curas total - e este registro também é levado em conta, juntamente com a taxa de auto-suficiência, isto é, privilegia os municípios que detêm maior cobertura de seus casos quanto ao atendimento e, consequentemente, de seu banco de dados. Isto pode não estar errado, mas certamente incorre em injustiça com os municípios de menor porte. Sendo assim, a melhor forma de se avaliar parece ser a análise dos dados por município de atendimento. Com a evolução do sistema de saúde, a análise por município de residência pode atingir maior grau de confiabilidade, na medida em que os municípios passem a se apropriar do acompanhamento de seus pacientes, sejam eles lá atendidos ou pelo menos conhecidos indiretamente por intermédio de um sistema de informação mais ágil.

\section{Itens não validados}

Ao analisar as matrizes de correlação para construir o indicador sintético, 
nem todas as variáveis puderam ser aproveitadas. Os itens que não puderam ser validados por apresentarem alguma correlação negativa merecem atenção.

TABELA 10. ASPECTOS DA VALIDAÇÃo DE UM INDICAdOR SINTÉTICO

\begin{tabular}{|l|l|}
\hline VALIDADE DE FACE & A medida é apropriada a seu propósito \\
\hline VALIDADE dE CONTEÚDo & $\begin{array}{l}\text { Abrange conteúdos suficientes para refletir o significado do conceito que está sendo } \\
\text { medido }\end{array}$ \\
\hline VALIDADE dE CONSTRUÇão & Fornece classificações que são consistentes com a teoria \\
\hline $\begin{array}{l}\text { VALIDADE RELACIONADA } \\
\text { AO CRITÉRIO }\end{array}$ & Suas respostas que se relacionam com outras avaliações, simultaneamente ou no futuro \\
\hline VALIDADE CLÍNICA & Fornece previsões que são úteis para decisões clínicas \\
\hline
\end{tabular}

O fato de uma variável não ser validada pode ter vários motivos. Os fatores que interferem na validação estão resumidos na Tabela 8 .

Neste estudo, as variáveis não validadas devem ser revistas e, num primeiro passo, analisadas quanto aos problemas mais prováveis:

- Se as evidências científicas não são robustas o suficiente (falta de validade de face);

- Se, apesar de haver evidências científicas quanto ao significado, a forma de construção das variáveis não foi adequada (por exemplo, falha na definição de numerador ou denominador, pontos de corte, etc.)

- Se as variáveis têm base sólida e são bem construídas, mas foram mal compreendidas por aqueles que produziram os dados, seja por falha do instrumento de coleta de dados na origem (notificações, boletins de acompanhamento) ou por problemas no registro desses dados (falta de entendimento do significado dos dados). 
- Se a informação é intencionalmente falha, o que pode ocorrer, principalmente se as conclusões puderem levar a vantagens e/ou desvantagens para os avaliados.

Pode-se aventar hipóteses sobre o porquê de alguns itens não terem sido validados.

Um item de indiscutível valor de face não foi compatível com os demais para avaliar a qualidade do tratamento. Trata-se da proporção de casos novos. Quando a proporção de retratamentos é alta, é evidente que a qualidade dos tratamentos iniciais foi baixa ${ }^{34}$. Pode-se aventar a hipótese de que haja falta de clareza na ficha de notificação - o item tratamento anterior (alternativas: não; sim, abandono e sim, alta-cura) pode estar sendo mal interpretado, sendo assinalada resposta positiva quando o paciente chega transferido de outros serviços.

Quando da construção das variáveis a serem testadas, foram incluídas algumas que tiveram por base recomendações de consensos $^{14}$, ou evidências científicas bastante consistentes. Se algumas não são compatíveis com as demais, não tendo portanto sido validadas no conjunto, isso reforça a importância e serem mostradas e analisadas ao se desenvolver a atividade de monitoramento, uma vez que seu significado talvez não esteja sendo bem compreendido pelas pessoas responsáveis pela geração dos dados.

Outras variáveis devem ser revistas quanto ao seu conteúdo. Por exemplo: é evidente que, num sistema de saúde mais bem organizado, a maioria dos casos podem ser descobertos em ambulatórios, o que é preferível aos prontos-socorros e hospitais. Porém, se o serviço mais procurado em determinado município é um pronto-socorro e a descoberta dos casos se dá principalmente em ambulatórios, este 
dado, ao invés de indicar boa qualidade nos ambulatórios, pode ser um sinal de falha na suspeição e/ou diagnóstico dos casos nos serviços de urgência

Ainda sobre a construção dos indicadores, o item "tipo de descoberta" deve ser também repensado. O modo de apresentação dos pacientes, segundo a ficha de notificação, é classificado em 1)apresentação espontânea devido aos sintomas respiratórios; 2) espontânea por outros sintomas; 3) encaminhado de outro local com suspeita e/ou diagnóstico de TB; e d) descoberta pelo controle de contatos. Não se prevê a descoberta por busca ativa na comunidade ou em instituições. Esta forma parece altamente desejável, tanto pelo fato aumento recente do número de agentes de saúde e equipes do Projeto de Saúde da Família, facilitando a busca ativa de casos nas residências, como pela preocupação cada vez maior com instituições como presídios, albergues para moradores de rua, casas de apoios a pacientes com Aids e asilos, locais onde a tuberculose pode ser transmitida a um grande número de pessoas. A expectativa de porcentagem de casos descobertos pelo exame de contatos gira em torno de $3,5 \%$ da incidência, o que faz com que o evento seja de ocorrência extremamente variável nos municípios menores. Por outro lado, a chegada do doente para tratamento já com suspeita e/ou diagnóstico pode até ser interpretada como favorável, sinal de boa integração desses serviços com o restante da rede pública ou particular.

O mesmo raciocínio vale para a ocorrência de internação, se a demanda reprimida e conseqüente baixo índice de internação em alguns locais pode ser uma falha e não virtude do Programa. Em resumo, mesmo que respaldadas pela evidência científica, condições outras que não a o desempenho do PCT influem na forma como 
as pessoas acorrem aos serviços de saúde e suas escolhas.

Na construção dos indicadores, algumas opções têm que ser feitas e nem sempre isso resulta em uma variável que consegue discriminar qualidade. Qual o ponto de corte para a demora entre o início dos sintomas e o tratamento, para este tipo de avaliação? Será que a demora menor de 8 semanas não discrimina suficientemente o bom do mau resultado, e então deveríamos calcular a porcentagem de casos cuja demora foi maior que 2 ou 3 meses? Ou o inverso, considerar a porcentagem de casos com demora menor que 1 mês, com base no conceito de sintomático respiratório, indivíduo com tosse por mais de 3 semanas?

Nesse aspecto, o ponto adequado para $\mathrm{o}$ indicador de número de baciloscopias de controle parece ter sido validado neste estudo. As normas nacionais e internacionais falam na sua realização até no sexto mês, mas a prática mostra que a adoção desse padrão nivela os municípios, pois raros casos têm esse exame realizado com tal regularidade, até porque muitos pacientes deixam de apresentar expectoração com o desenrolar do tratamento.

\section{Agregando variáveis para um indicador-resumo: Utilidade do}

\section{indicador escalar}

Em primeiro lugar, é preciso refletir sobre a razão de não se haver conseguido agregar todos os itens referentes à busca de casos, diagnóstico e tratamento. Se algumas das variáveis não podem integrar o mesmo conjunto, isso sugere que os condicionantes para o bom desempenho de cada aspecto do PCT sejam de alguma forma diferentes. 
O doente, ao decidir-se a procurar assistência médica, dirige-se ao serviço de saúde que julga mais adequado ou acessível - uma grande variedade de instituições, conforme a rede de saúde em cada local. De lá, pode ser encaminhado a um outro serviço, para ser tratado. Há municípios em que um único serviço de saúde é responsável pelo tratamento dos casos. Dada a multiplicidade de atores envolvidos na primeira etapa e o número mais reduzido no processo de tratamento, é de se esperar uma freqüência apreciável de municípios com dissociação entre a qualidade da busca de casos/diagnóstico e a do tratamento. Para o bom funcionamento do SUS, entretanto, é necessário integrar os vários serviços de saúde num mesmo objetivo, e esta é uma tarefa a ser construída em cada município e em cada atividade.

Outro ponto que merece reflexão é o peso atribuído a cada etapa do programa. Note-se que, na construção dos indicadores sintéticos parciais já está embutida a atribuição de peso. A realização de baciloscopia de escarro é levada em consideração tanto na variável Realização de baciloscopia para casos pulmonares, como na Confirmação bacteriológica dos casos pulmonares. Analogamente, da forma como Controle baciloscópico dos casos baciliferos e negativação da baciloscopia foram construídos, o controle bacteriológico é valorizado em ambos.

Essa forma de construção pode ser denominada, segundo Paes de Barros ${ }^{68}$, como "indicador em cascata" e vem sendo utilizada em outros campos, como por exemplo na economia, para composição de indicadores escalares de desenvolvimento social. Ela propicia a atribuição de maior peso a alguma característica julgada importante, mesmo quando, no cálculo do indicador sintético, as variáveis recebem peso igual. 
Variáveis que apresentavam apenas pequenas diferenças na construção como, por exemplo, "taxa de cura total" e "taxa de cura dos casos encerados" ; "confirmação bacteriológica total", "confirmação bacteriológica dos casos novos" e "confirmação bacteriológica dos casos pulmonares", foram testadas apenas para verificação da melhor maneira de construção do indicador sintético, não sendo colocadas simultaneamente no mesmo rol de itens, embora, pelo mesmo princípio dos indicadores em cascata, isso não seja considerado errado.

Por outro lado, as variáveis validadas nos indicadores de diagnóstico e nos de tratamento não foram exatamente iguais às que puderam ser incluídas no indicador-resumo. Veja-se que a taxa de curas, tal como foi construída, teve que ser substituída pela razão de adesão, que leva em conta somente os casos com desfecho "cura" ou "abandono" e não os óbitos, por exemplo. Isso leva à hipótese de que de alguma forma os indicadores parciais estão medindo objetos um pouco diferentes do indicador sintético ou que a imprecisão dos dados leve a estas diferenças. Poderia ser questionado, então, a conveniência de se adotar somente o indicador sintético.

O motivo que leva à proposta aqui apresentada, de se utilizarem indicadores intermediários, é de ordem prática e não técnica. Se o objetivo do instrumento é a possibilidade de ser utilizado na tomada de decisões, quanto mais intuitivos os conceitos, melhor para sua difusão. Dizer que a taxa de cura é $83 \%$ é de compreensão muito melhor que dar o valor da taxa de adesão. Perde-se um pouco na precisão técnica, mas ganha-se muito na qualidade do processo de informação. 


\subsection{AGRUPAMENTO DOS MUNICÍPIOS SEGUNDO DESEMPENHO NO PCT}

A análise de "clusters", realizada segundo os indicadores sintéticos de busca/diagnóstico e para tratamento, está representada nos dendogramas reproduzidos nos Figuras 2 e 3.

Considerando-se a distribuição por residência, os municípios podem ser divididos em 11 grupos, segundo suas semelhanças em relação esses dois aspectos do PCT, aos quais denominou-se G1 a G11 (Figura 2).

Quando se obtém os dados segundo município de atendimento, os municípios se agrupam de maneira um tanto diferente, formando 12 "clusters". A Figura 3 exibe o gráfico de agrupamento dos municípios segundo local de atendimento dos casos. 


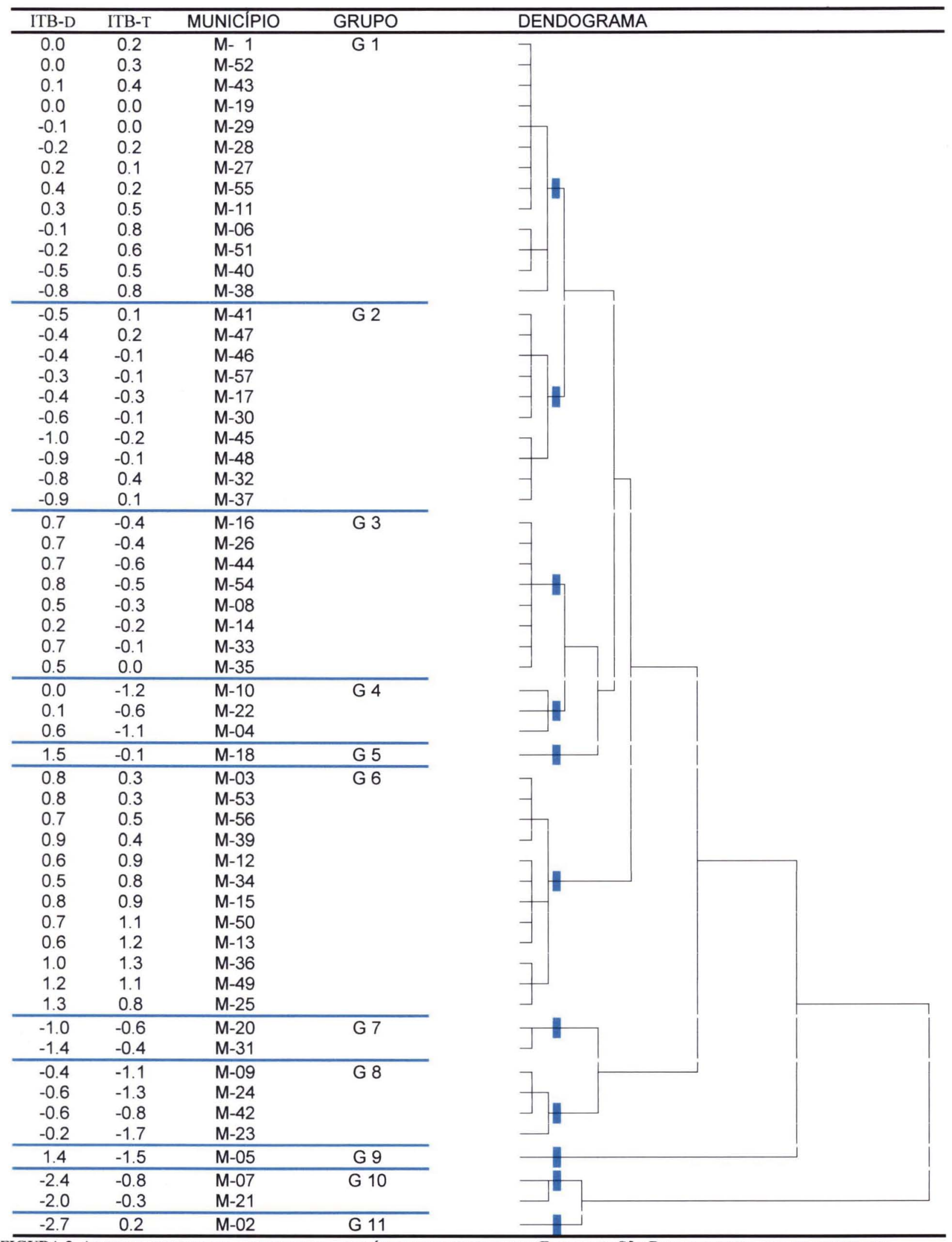

FIGURA 2. AGRUPAMENTO DE UM CONJUNTO DE MUNICÍPIOS SELECIONADOS DO ESTADO DE SÃO PAULO, SEGUND ODESEMPENHO NOS INDICADORES SINTÉTICOS ITB-D (QUALIDADE DO DIAGNÓSTICO) E ITB-T (QUALIDADE DO TRATAMENTO) NO ANO DE 2002,

DADOS COMPUTADOS POR MUNICÍPIO DE RESIDÊNCIA 


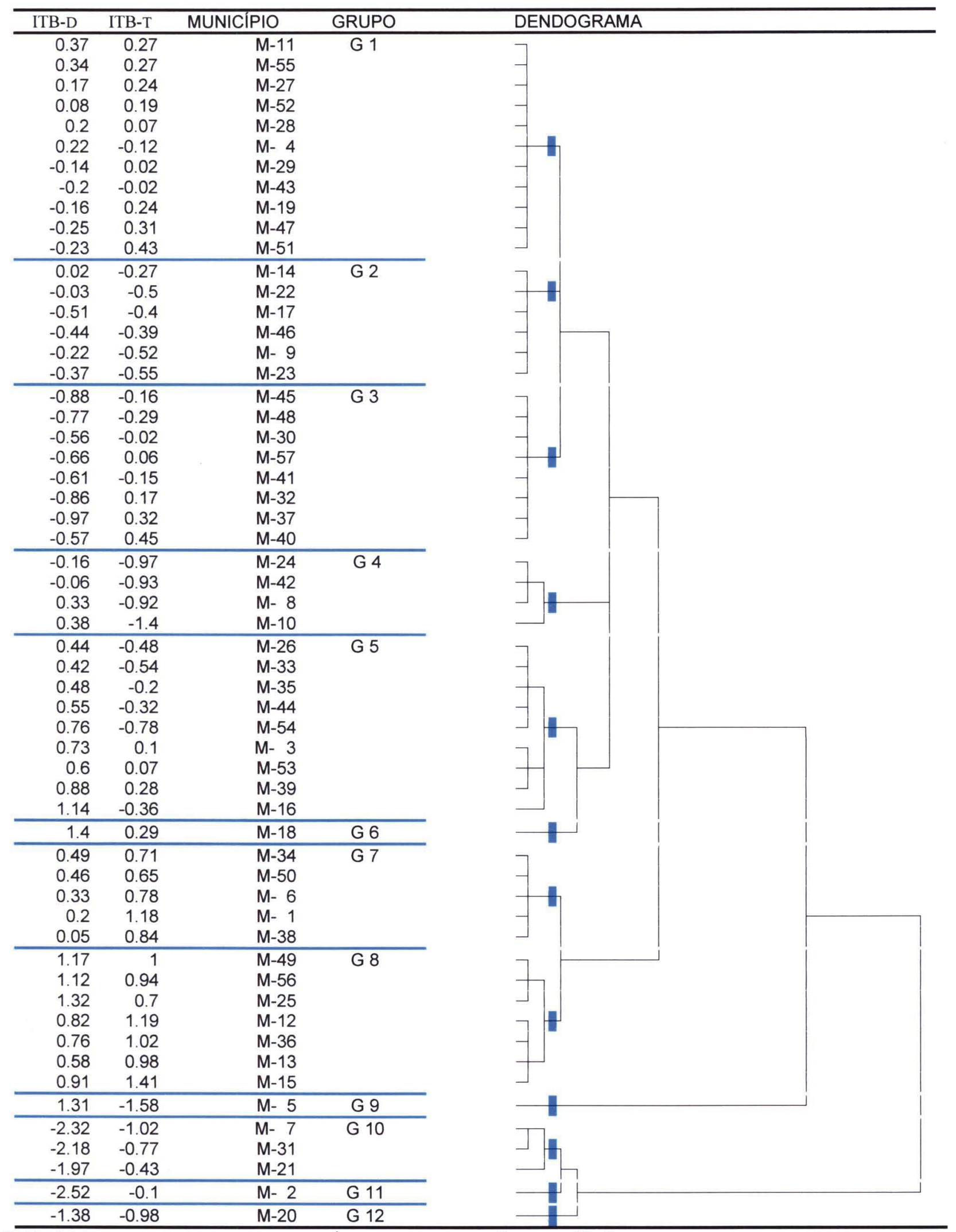

FigURA 3 AGRUPAMENTO DO CONJUNTO DE MUNICÍPIOS SELECIONADOS DO ESTADO DE SÃo PAULO, SEGUNDO DESEMPENHO NOS INDICADORES SINTÉTICOS ITB-D (QUALIDADE DO DIAGNÓSTICO) E ITB-T (QUALIDADE DO TRATAMENTO) NO ANO DE 2002. DADOS COMPUTADOS POR MUNICÍPIO DE ATENDIMENTO 


\subsubsection{Agrupamento segundo município de residência}

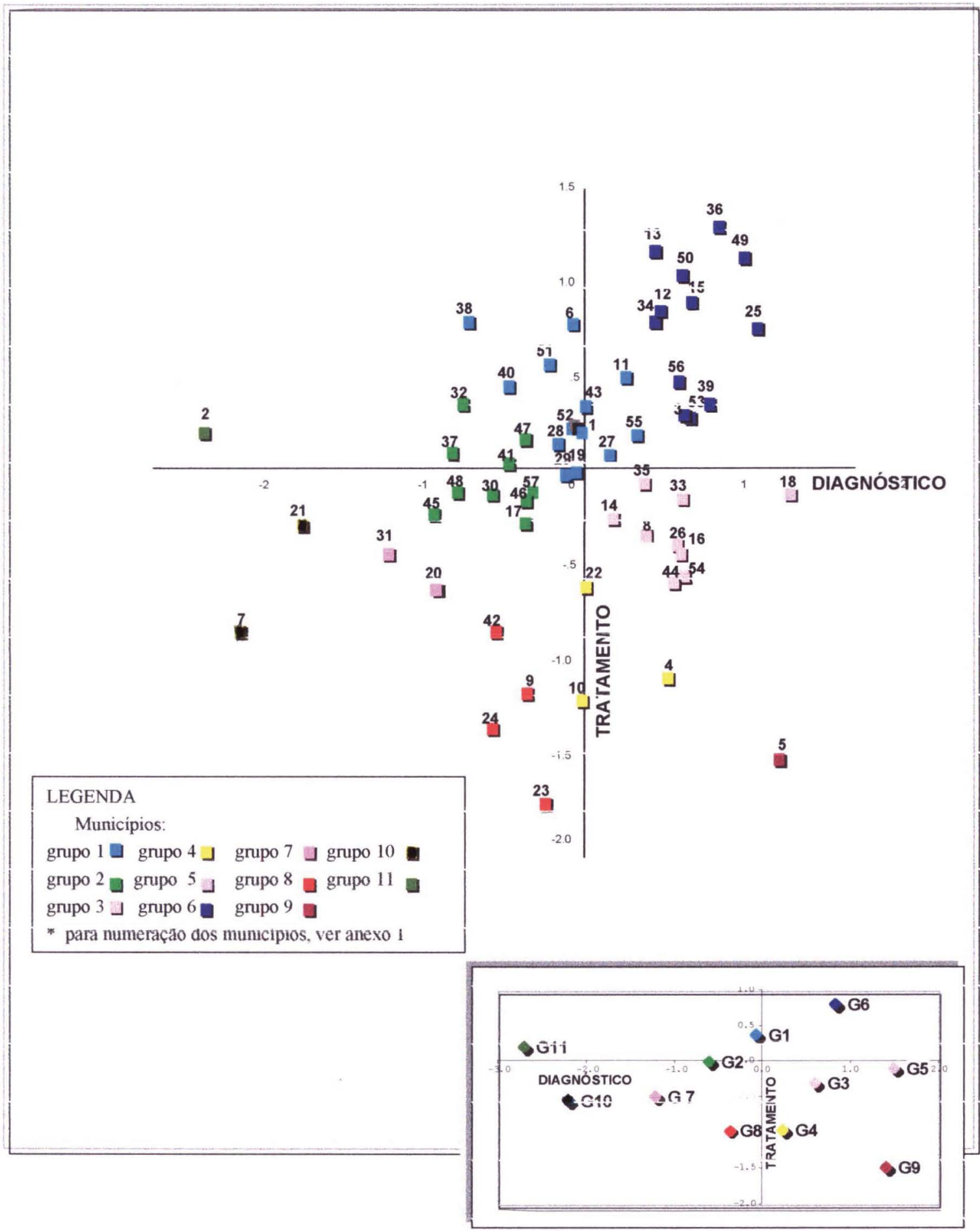

FIGURA 4. AGRUPAMENTO DOS MUNICIPIOS SELECIONADOS*, SEGUNDO VALORES OBTIDOS NO ITB-D (DIAGNÓSTICO) E ITB-T (TRATAMENTO), COMPUTADOS POR LOCAL DE RESIDÊNCIA.

- NO DETALHE, OS GRUPOS $1,2,3, \ldots, 12$. EST ÃO REPRESENT ADOS RESPECTIVAMENTE COMO G1, G2, G3, ... G12.

Como esperado, a maioria dos municípies têm valores próximos ao ponto

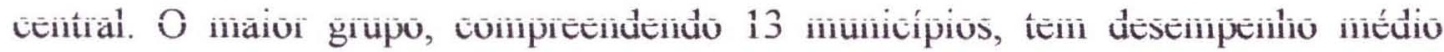


PCT, aos quais denominou-se G1 a G11 (Figura 4).

Como esperado, a maioria dos municípios têm valores próximos ao ponto central. O maior grupo, compreendendo 13 municípios, tem desempenho médio quanto ao diagnóstico dos casos e um pouco acima na qualidade do tratamento e foi chamado G1. O grupo 2 (G2), com 10 municípios, apresenta desempenho médio no tratamento e um pouco mais baixo no diagnóstico. O desempenho do G3, com 8 municípios, é um pouco acima no diagnóstico e abaixo na qualidade do tratamento.

No quadrante negativo, com resultados ruins tanto em diagnóstico como no tratamento, estão os 2 municípios do G7 e outros 2 do G10, com a diferença de terem estes últimos um grau de qualidade de diagnóstico mais precário que aqueles do G7.

Já o G4, de 3 elementos, e o G8, com 4 municípios, têm maus resultados de tratamento e se aproximam da média na qualidade do diagnóstico, sendo o do G 4 um pouco melhor do que o do G8.

Doze municípios se agrupam pelo fato de serem melhores que os demais nos dois quesitos, formando então o G6.

O G5, o G9 e o G11 não são propriamente grupos. São municípios cuja combinação de resultados nos quesitos diagnóstico e tratamento não se assemelhou a nenhum outro, constituindo portanto "grupos" de um só elemento.

\subsubsection{Agrupamento segundo município de atendimento}

Quando se obtém os dados segundo município de atendimento, os municípios se agrupam de maneira um tanto diferente, formando 12 "clusters". A Figura 3 exibe o gráfico de agrupamento dos municípios segundo local de 


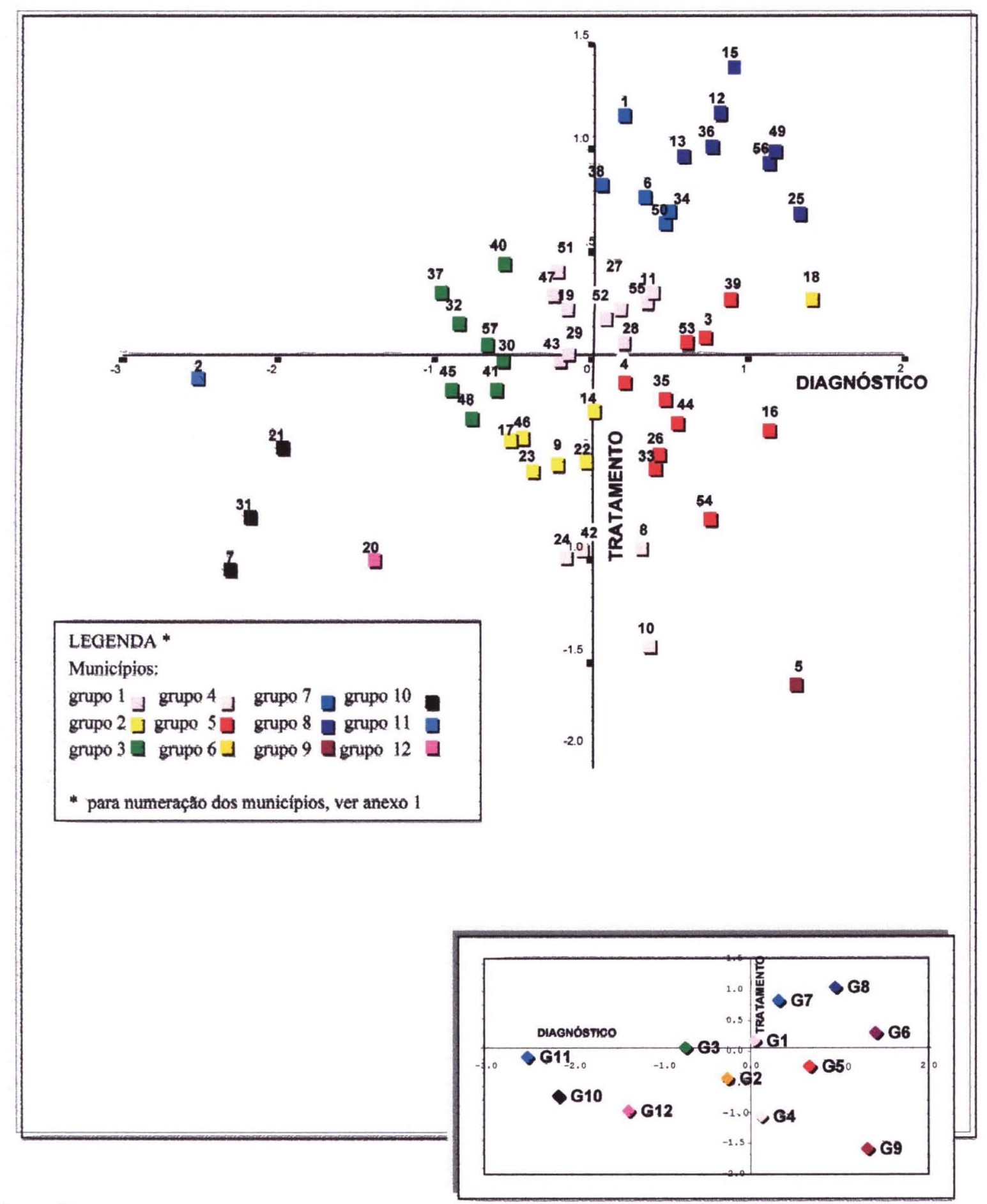

FiguRA 5.AGRIPAMENTO DOS MUNICIPJOS SELECIONADOS*, SEGUNDO VALORES OBTIDOS NO ITB-D (DLAGNÓSTICD) E ITB-T (TRATAMENTO), COMPUTADOS POR LOCAL DE ATENDIMENTO

* NO DETALHE, OS GRUPOS $1,2,3, \ldots, 12$. ESTÃO REPRESENTADOS RESPECTIVAMENTE COMO G1, G2, G3, ... G12.

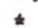

Um grupo de 4 municípios, o G4, apresenta resultados de tratamento baixos e desempenho central no diagnóstico.

No quadrante superior direito colocam-se os grupos com destaque no 
municípios, ligeiramente abaixo da média em ambos os quesitos; G3, de 8 elementos, central no desempenho quanto ao tratamento e um pouco abaixo no diagnóstico; e G5, um pouco acima da média na qualidade do tratamento e abaixo em busca de casos e diagnóstico.

Um grupo de 4 municípios, o G4, apresenta resultados de tratamento baixos e desempenho central no diagnóstico.

No quadrante superior direito colocam-se os grupos com destaque no desempenho: G7, de 5 municípios e G 8, o melhor, com 7 municípios.

Há ainda três municípios numa posição desfavorável nos dois quesitos, sendo mais precários na qualidade do diagnóstico, formando o G10.

Isolados, não têm valores semelhantes a nenhum grupo um município com alto valor em diagnóstico e muito baixo em tratamento (G9), outro de desempenho muito abaixo dos demais em diagnóstico (G11) e um que deixa muito a desejar nos dois quesitos.

\subsubsection{Discussão}

Do modo como as atividades ocorrem na maioria dos municípios, vemos que, ao adoecerem, os pacientes procuram uma grande variedade de serviços de saúde, conforme suas possibilidades. Isso é ainda mais evidente para doença cujos sintomas não são específicos. O processo de diagnóstico é um pouco mais restrito muitas vezes o paciente precisa ser encaminhado para realizar exames complementares em outro serviço de saúde. Já o tratamento, na maioria dos municípios do Estado, é concentrado em serviços de referência. Sendo estes, em 
geral, compostos por equipes relativamente pequenas, muito de sua qualidade pode ser decorrência de capacitação dessa equipe, sem que isso necessariamente esteja relacionado à maneira como está estruturada a atenção médica no município.

Havendo consistência nessa hipótese, fez sentido agrupar os municípios conforme seu desempenho nessas esferas, já que a qualidade dos processos de busca de casos, diagnóstico e tratamento da tuberculose podem ser substancialmente diferentes em âmbito municipal.

Observando a distribuição dos municípios nos grupos, é possível traçar estratégias e determinar prioridades de atuação conjunta que, ao contrário da abordagem tradicional baseada em divisões administrativas, sejam talhadas de acordo com semelhanças nos problemas e necessidades. Não sendo possível levar em conta o desempenho no quesito busca de casos, perde-se em abrangência da análise: a distribuição passa a ser bidimensional, o que esconde diferenças importantes.

Suponha-se, por exemplo, que dois municípios sejam colocados no mesmo grupo por seu bom desempenho em diagnóstico e tratamento. Imagine-se que um deles tenha somente um serviço de saúde que realize essas atividades, com boa orientação técnica e pessoal motivado, mas que não haja uma boa integração deste com os outros serviços da região, que atendem grande número de doentes. Os casos podem chegar com grande retardo ao único serviço encarregado de firmar diagnóstico e tratar. Situação diferente pode ocorrer no outro município do mesmo grupo: uma ampla rede de serviços, toda ela atenta aos sintomáticos respiratórios, bem integrada e de boa qualidade técnica. É evidente que a abordagem desses dois municípios deve ser distinta - o primeiro demanda ações amplas de integração. A 
semelhança com a realidade não é mera coincidência: observando-se a distribuição dos grupos, quem estiver familiarizado com a situação do PCT no Estado poderá reconhecer no primeiro exemplo vários municípios onde o PCT é centralizado e a rede de serviços, especialmente os particulares e conveniados, é bastante desenvolvida. Se o sistema de informação pudesse avaliar a qualidade da descoberta de casos, o gráfico ilustraria uma distribuição tridimensional - apenas como exemplo, foi anexado um gráfico em que foram plotados os municípios segundo os três eixos: ITBB, ITBD e ITBT, o que seria válido se o indicador sintético de busca de casos pudesse ser utilizado

Mesmo com essa limitação, a distribuição em grupos traz muitas informações para orientar a ação. Em municípios situados nos dois quadrantes inferiores, os serviços que tratam os casos demandam atenção mais urgente - os grupos ali situados têm desempenho inferior em qualidade do tratamento. Eles poderão ser priorizados para treinamento, supervisões e outras atividades dirigidas aos serviços responsáveis por essa atividade. Para aqueles do quadrante inferior esquerdo, o enfoque deverá ser diferente, abrangendo também a questão do diagnóstico possivelmente numa rede mais ampla de serviços de saúde mas o foco prioritário talvez seja a organização do tratamento e a motivação dos funcionários para melhorar, em primeiro lugar, o desempenho quanto ao tratamento, preparandoos para conduzir com segurança os casos que forem detectados.

Além disso, a análise dos agrupamentos revela ainda que os grupos situados no quadrante superior esquerdo devem necessitar de uma discussão ampla sobre a inserção do PCT no sistema de saúde do município, já que neles o diagnóstico deixa 
mais a desejar que o tratamento. O gargalo do PCT nesses locais parece ser mais localizado na fase pré-tratamento, porém os responsáveis por prescrever os medicamentos podem estar incorrendo no erro de aceitar casos não confirmados, arriscando-se a aceitar falsos diagnósticos.

Os grupos do quadrante inferior direito apresentam uma dissociação entre o diagnóstico e os resultados de tratamento. Na hipótese de serem os dados fidedignos, é possivel que a maior ênfase deva ser dirigida à estruturação da equipe de coordenação ou que haja falha localizada no desempenho de algum profissional em função-chave relacionada ao tratamento, pois esses municípios parecem ter uma boa estrutura geral para busca e diagnóstico, falhando na condução dos casos a um desfecho favorável. $\mathrm{O}$ efeito dessa situação pode ser paradoxalmente perverso: diagnosticar muito bem e não levar à cura pode resultar em aumento da incidência e, pior, dos casos resistentes aos medicamentos. Deve ser investigada, também, a hipótese de falha no sistema de informação - a evolução do tratamento pode não estar sendo convenientemente informada, por exemplo. Vale lembrar que os casos de dissociação entre a qualidade de um quesito e de outro devem ser analisados com cuidado redobrado.

O gráfico nos revela, também, os municípios que se destacam em ambas as dimensões do programa - a observação detalhada desses grupos pode ajudar a compreender quais os fatores que os levaram a se diferenciar dos outros e como esse melhor resultado pode ser estendido aos demais.

\subsubsection{Características dos municípios e desempenho no PCT}

A comparação dos dados por município de residência e de tratamento 
também pode ser esclarecedora. Os gráficos das Figuras 3 e 2 permitem individualizar os municípios em relação aos atributos diagnóstico e tratamento.

Veja-se o caso do município de número 56, alocado no grupo 6 na análise por residência e grupo 8 por atendimento. Seu desempenho com os casos lá atendidos é muito superior aos resultados quando se leva em conta o total de pacientes residentes. O gráfico ajuda a detectar esse problema e a orientar esforços para que os pacientes passem a se tratar no próprio município de residência. $O$ município poderá ser orientado a estudar por que os doentes se tratam em outro município, o que os está atraindo. O município poderá compartilhar, por exemplo, o acompanhamento do tratamento e as atividades de controle de contatos, aumentando a confiança da população e a adesão ao município de residência. Intensificando a comunicação com o município-polo, adequando horários de atendimento e redirecionando o tratamento para o município de residência, o resultado poderá ser benéfico para os pacientes.

Ao se observar a distribuição dos municípios nos grupos, algumas particularidades chamam a atenção. Pode-se verificar, por exemplo, que os municípios de maior porte tendem a se concentrar próximo à média. Nos grupos 1,2 , 3,5 e 7 , cujas coordenadas não ultrapassam o raio de \pm 1 , estão todos os municípios acima de 400 mil habitantes e 7 dos 9 municípios com população entre 300 e 400 mil. É provável que isso se deva ao fato de seus resultados dependerem de uma multiplicidade de atores - serviços de saúde, organizações profissionais e outros. Mas somente 3 municípios se situaram no grupo 1, mais próximo ao ponto central. Isso significa que, embora a tendência seja não se afastarem muito da média, há 
diferenças que podem ser consideradas: mesmo que aparentemente pequenas, se positivas, podem significar que houve esforços dos responsáveis municipais pelo programa, os quais, se apoiados, resultarão em benefícios para muitos pacientes. No sentido inverso, mesmo próximos da média, municípios grandes que ficaram nos quadrantes inferiores devem receber atenção redobrada e reforço nas equipes de coordenação. Os dois municípios na faixa dos 300 mil habitantes que se distanciaram mais da média ficaram nos quadrantes inferiores - um com valor fortemente negativo somente no tratamento e outro nos dois quesitos. Esses, é evidente, precisam ser atentamente monitorados.

Outra forma de analisar a distribuição dos municipios é a comparação de sua distribuição de desempenho segundo região do Estado. Grosso modo, pode-se dividir os municípios de São Paulo em três regiões, além da Capital: os da Região Metropolitana de São Paulo ("Grande São Paulo"), cujo coeficiente de incidência de tuberculose tem se situado em torno de 65 a 70 casos por 100 mil habitantes, os da Baixada Santista, com os maiores coeficientes do Estado, ao redor de 100 a 120 casos por 100 mil, e os demais municípios do interior, cujos coeficientes variam de 30 a 70 casos por 100 mili. $^{i}$.

Ao observar a distribuição do desempenho no PCT, percebe-se algumas particularidades interessantes. Nenhum dos 4 municípios do litoral se posicionou muito abaixo da média com relação ao tratamento, mas só um deles se destacou positivamente quanto ao diagnóstico, colocando-se no grupo 8. Neste mesmo grupo,

\footnotetext{
ii Esta forma de divisão tem sido utilizada pelo Centro de Vigilância Epiderniológica para analisar regiōes do Estado quanto à vigilância da resistência medicamentosa [informação pessoal].
} 
o de melhor desempenho, colocaram-se 2 municípios do interior e mais 4 municípios vizinhos, da Grande São Paulo, o que não deve ser casual. De fato, sua história mostra que pertencem a uma região de grandes problemas sociais, porém com boa tradição gerencial na área da saúde. Quase todo o restante dos municípios da Região Metropolitana de São Paulo foram alocados nos grupos em torno da média ou acima dela. Dois municípios dessa região, com valores bastante baixos para tratamento, devem ser motivo de preocupação, juntamente com um do litoral e 7 do interior, colocados nos grupos $4,9,10$ e 12 , sendo que o município colocado no grupo 11 , do interior, alcançou valor médio em tratamento e baixo no diagnóstico.

Esta análise, embora superficial, mostra a potencialidade do agrupamento dos municípios enquanto ferramenta de apoio gerencial. É evidente que este não é suficiente para conclusões a respeito de causalidade ou de desempenho de pessoas nos municípios. Para isso, outros fatores precisam ser levados em conta, já que não foi considerada a situação prévia e nem tampouco outros determinantes como a os fatores econômicos, políticos e sanitários desses municípios. Mas o instrumento pode apontar possíveis fraquezas ou virtudes e motivar aproximações, sejam quantitativas ou qualitativas, que esclareçam esses pontos e colaborem na resolução dos pontos de estrangulamento do programa.

\subsection{CARTA de AVAliaÇão}

\subsubsection{Construção das cartas gráficas comparativas}

Para cada município, foi produzida uma carta gráfica comparativa, abrangendo todos casos tratados no município, não importando onde residam. 
O instrumento resultante mostra em qual categoria o município se encontra, comparativamente aos demais, quanto a cada indicador, o que foi graficamente representado por asteriscos. Isso permite a compreensão intuitiva, facilitando a detecção dos pontos fortes e das fragilidades do PCT no município. Expõe também a classificação do município em relação ao conjunto, conforme o valor obtido no ITB.

A carta mostrou-se de fácil interpretação, propiciando a detecção dos pontos fracos e fortes do programa em âmbito municipal.

\subsubsection{Discussão}

Os itens mostrados na carta de avaliação foram limitados àqueles validados neste estudo. É possível, para fins práticos no monitoramento do programa, incluir outras informações, como o coeficiente de incidência, a taxa de abandonos de tratamento, taxa de óbitos, ou mesmo indicadores provenientes de outras fontes de dados, como o número de exames laboratoriais realizados, de sintomáticos respiratórios examinados, taxa de mortalidade específica, porcentagem de casos resistentes, etc. Esses dados podem ser tratados da mesma forma, classificando os resultados dos municípios nos grupos segundo gravidade da situação. Se isto for feito, deve-se lembrar de inverter o sinal para as variáveis que tiverem significado negativo, como a mortalidade, a prevalência de casos resistentes e outras que tenham essa característica. $\mathrm{O}$ limite do número de itens a ser incluído dependerá do bom senso, com equilíbrio entre a facilidade de manuseio e compreensão e, por outro lado, o interesse das informações para direcionamento do programa.

Os itens não validados poderiam ser mostrados à parte. $\mathrm{O}$ fato de não serem compatíveis com os demais, não sendo incorporados no cálculo do indicador 
sintético, pode ser devido à falta de compreensão do seu significado pelas pessoas responsáveis pela informação nos municípios. Isso reforça a importância de serem mostrados e analisados ao se desenvolver a atividade de monitoramento - assim, o conhecimento de seus próprios dados pelas equipes dos municípios pode levar ao aumento da confiabilidade do sistema. Seria aconselhável que a eles não fosse atribuído valor (representado pelos asteriscos), dado que estatisticamente não foram consistentes para medir desempenho.

Trnka e Danková ${ }^{96}$, ao discorrerem sobre a validade das notificações de tuberculose, sugerem que faça parte da rotina do sistema de vigilância a revisão dos critérios de diagnóstico de todos os casos de tuberculose, bem como a análise da consistência entre dados de laboratório e número de casos notificados. Isso pode ser estimulado, desde que os responsáveis pela vigilância da doença se apropriem melhor de seus dados.

Como a finalidade das cartas gráficas comparativas é servir para o monitoramento do PCT nesses municípios, algumas questões se colocam: a) A quem serão destinadas? b) $\mathrm{O}$ município deve ter acesso às cartas gráficas de outros municípios? c) Este instrumento deve se ater aos dados segundo município de residência ou local de tratamento? d) Qual o volume e o teor das informações a serem incluídas? e) Deve constar o valor obtido nos indicadores sintéticos? f) Outras informações, sem conotação de avaliação, poderiam ser exibidas? g) Qual a forma de entrega deste instrumento e qual a sua periodicidade?

A maior parte destas indagações devem ser respondidas mais pelo ângulo estratégico do que técnico. Os gestores municipais do setor saúde são os principais 
usuários das informações nelas contidas, dado que suas decisões se beneficiariam do conhecimento delas. Mas definir os usuários secundários dependerá de decisões que devem levar em conta outros fatores.

A divisão em cinco categorias e a utilização do quintil como ponto de corte parece adequada. A compreensão intuitiva da classificação de desempenho em cinco categorias é utilizada em uma ampla gama de situações, até mesmo nos bancos escolares. Em sendo aplicado, o significado dos dados apresentados neste instrumento precisará ser devidamente esclarecido: se a taxa de curas do município se colocou no quarto quintil, isso não significa que esteja "quase boa", mas sim que pelo menos $3 / 5$ dos municípios avaliados obteve taxa abaixo desta e pelo menos $1 / 5$ a superou, ou seja, a marca atingida pelo município neste item está entre as do quarto grupo entre cinco. As informações contidas na carta permitem apenas verificar a posição relativa do município em relação aos demais, não tendo o objetivo de medir a distância de metas ideais.

Arantes e colaboradores ${ }^{10}$ sugeriram a emissão de cartas gráficas baseadas em unidades desvio padrão, como aquelas utilizadas no Japão ${ }^{86}$; para a medidasíntese, utilizaram a somatória algébrica dos valores alcançados nas variáveis de significado positivo, menos os valores das variáveis de resultado negativo.

O motivo para a opção de basear as cartas gráficas em quintis, adotadas neste trabalho, e não em unidades desvio-padrão, foi facilitar a compreensão dos gestores do programa nos municípios. Esta também foi a razão de serem escolhidos indicadores todos com sentido positivo: confirmação do diagnóstico, taxa de cura, porcentagem de casos com demora até 8 semanas, etc. Isso obrigou a deixar de lado 
variáveis importantes como taxa de abandonos, letalidade, etc., que tiveram que ser transformadas em razão de adesão, taxa de sobrevida, etc. Se, por um lado, essas variáveis tiveram que ser desprezadas, por outro lado ganhou-se na compreensão intuitiva das cartas gráficas. No trabalho de Arantes e colaboradores ${ }^{10}$ foi visto que há variáveis, inclusive, que não têm necessariamente um sentido único. Neste trabalho algumas variáveis também demandaram reflexões desse tipo, mas foram excluídas da análise. Como exemplo pode-se citar a proporção de casos em crianças, que tanto pode significar um bom programa - que detecta casos pelo exame de contatos - como um mau programa - grande exposição a fontes de contágio.

Um instrumento como a carta de avaliação, evidenciando o desempenho do município em comparação com seus pares, mostrando a situação de um programa sob várias dimensões ao mesmo tempo, parece ser bastante útil para direcionar ações no sentido de melhorar a eficiência do programa.

Emitir a carta segundo município de residência ou de atendimento é outro ponto a ser definido. Optou-se, neste trabalho, por emitir esta carta por local de atendimento devido à maior confiabilidade dos indicadores sintéticos. A estratégia de pactuação de metas do SUS está ainda em fase de construção e, atualmente, as metas do PCT são definidas segundo município de residência dos casos. Se os casos atendidos no município forem considerados de sua responsabilidade (e clinicamente o são), opte-se por este critério para monitoramento. Se prevalecer o entendimento da responsabilidade do município por sua população (o que também é defensável), a carta deve manter esta lógica e ser reformulada quanto à validação dos indicadores. Qualquer das duas opções tem ganhos e perdas em relação à outra - qualquer uma 
delas pode levar a injustiças. Para alguns municípios, particularmente aqueles muito próximos a grandes centros, os dados podem ser substancialmente diferentes nas duas alternativas.

\subsubsection{Exemplo de carta de avaliação}

Para ilustrar a apresentação gráfica da carta de avaliação, vejam-se aquelas emitidas para os municípios de número 6 (Figura 6) e 5 (Figura 7). Por suposição, estas cartas serão enviadas aos municipios, ou discutidas em reuniões de avaliação, acompanhadas de uma explicação sobre o modo como foram obtidos os escores.

Tendo em mãos a carta de avaliação, o responsável pela coordenação da tuberculose no município 6 verá que seu município teve bom desempenho no programa, porque em nenhum quesito os seus indicadores tiveram marcas negativas. Mas verá também que ainda pode melhorar. Pela simples observação ele pode verificar, por exemplo, que seu desempenho no aspecto confirmação bacteriológica foi apenas mediano. Como a realização de baciloscopia superou este item, isso talvez seja devido ao fato de muitos casos já chegarem ao local de tratamento com diagnóstico firmado. Isso poderá levá-lo a traçar um projeto de treinamento de profissionais para descentralizar o tratamento, evitando que o paciente seja encaminhado para tratamento longe de sua residência, ou talvez incrementar a disponibilidade da cultura como método auxiliar de diagnóstico. Também no quesito tratamento seu ponto mais fraco parece ser a utilização de laboratório, uma vez que a proporção de casos em que é realizado o teste anti-HIV também é apenas mediana, mas pode ocorrer que este teste não seja oferecido com a devida intensidade. Quanto à taxa de curas, e controle bacteriológico durante o tratamento, verá que está situado 
entre os melhores entre os municípios analisados. Na escala desempenho no PCT, este município se posicionou em $9^{\circ}$ lugar entre os 57 do conjunto. Não satisfeito, poderá partir para a comparação da taxa de curas com a meta programática $(85 \%$ de cura ou mais) e com seu próprio desempenho em anos anteriores.

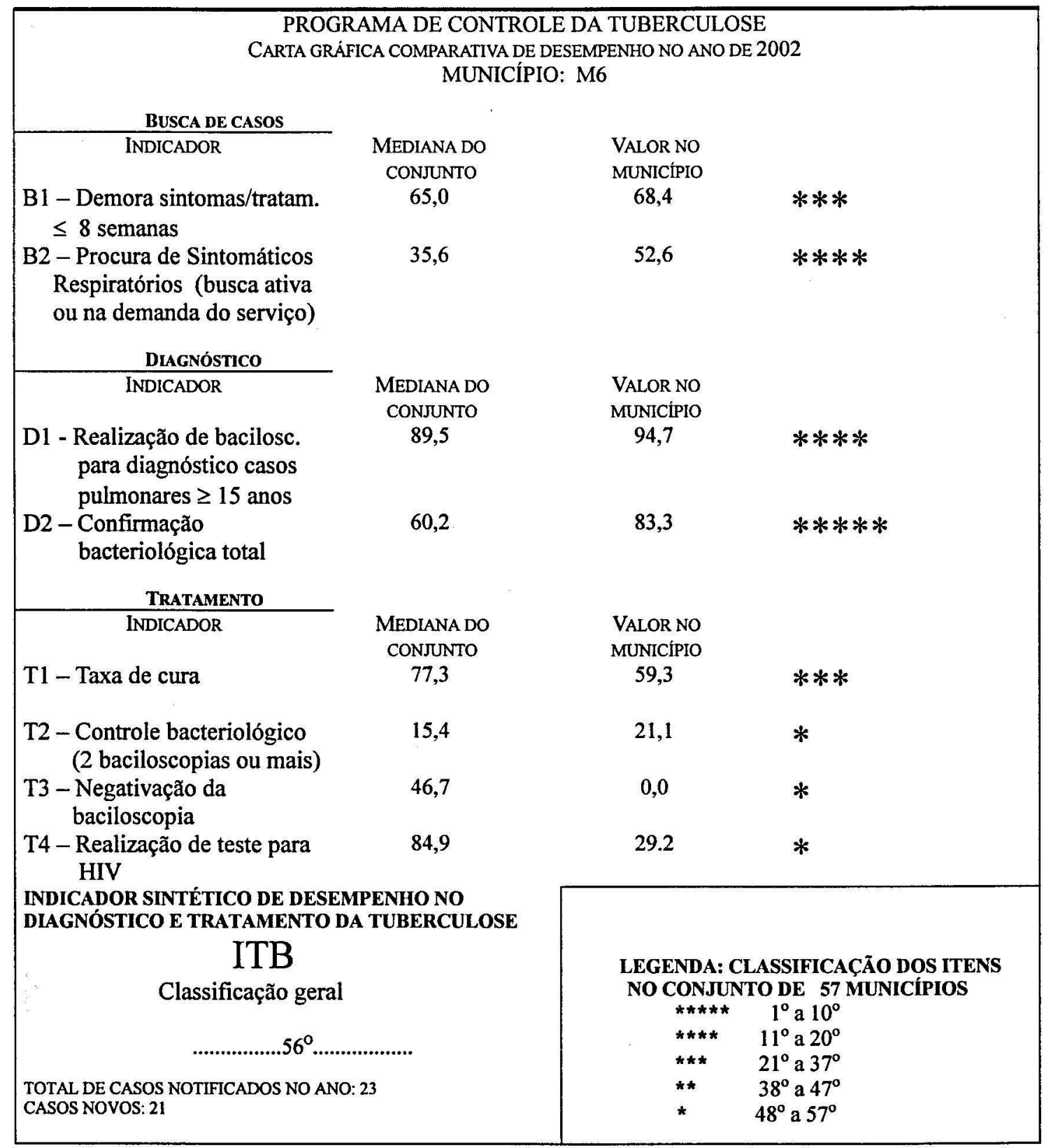

Figura 6 . Carta comparativa de avaliação de desempenho no Programa de Controle da Tuberculose no MUNICIPIO M6, ANO 2002 


\begin{tabular}{|c|c|c|c|}
\hline \multicolumn{4}{|c|}{$\begin{array}{l}\text { PROGRAMA DE CONTROLE DA TUBERCULOSE } \\
\text { CARTA GRÁFICA COMPARATIVA DE DESEMPENHO NO ANO DE } 2002 \\
\text { MUNICÍPIO: NÚMERO } 5\end{array}$} \\
\hline \multicolumn{4}{|l|}{ Busca de CASOS } \\
\hline INDICADOR & $\begin{array}{l}\text { MEDIANA DO } \\
\text { CONJUNTO }\end{array}$ & $\begin{array}{l}\text { VALOR NC } \\
\text { MUNICIPIC }\end{array}$ & \\
\hline $\begin{array}{l}\text { B1 - Demora sintomas/tratam. } \\
\leq 8 \text { semanas }\end{array}$ & 65,0 & 75,0 & $* * * *$ \\
\hline $\begin{array}{l}\text { B2 - Procura de Sintomáticos } \\
\text { Respiratórios (busca ativa } \\
\text { ou na demanda do serviço) }\end{array}$ & 35,6 & 50,0 & $* * * *$ \\
\hline \multicolumn{4}{|l|}{ Diagnóstico } \\
\hline INDICADOR & $\begin{array}{l}\text { MEDIANA DO } \\
\text { CONJUNTO }\end{array}$ & $\begin{array}{l}\text { VALOR NC } \\
\text { MUNICIPIC }\end{array}$ & \\
\hline $\begin{array}{l}\text { D1 - Realização de bacilosc. } \\
\text { para diagnóstico casos } \\
\text { pulmonares } \geq 15 \text { anos }\end{array}$ & 89,5 & 93.9 & $* * * *$ \\
\hline $\begin{array}{l}\text { D2 - Confirmação } \\
\text { bacteriológica total }\end{array}$ & 60,2 & 60,2 & $* * *$ \\
\hline \multicolumn{4}{|l|}{ TRATAMENTO } \\
\hline INDICADOR & $\begin{array}{l}\text { MEDIANA DO } \\
\text { CONJUNTO }\end{array}$ & $\begin{array}{l}\text { VALOR NC } \\
\text { MUNICIPIC }\end{array}$ & \\
\hline T1 - Taxa de cura & 77,3 & 81,6 & $* * * *$ \\
\hline $\begin{array}{l}\mathrm{T} 2 \text { - Controle bacteriológico } \\
\text { ( } 2 \text { baciloscopias ou mais) }\end{array}$ & 15,4 & 34,1 & $* * * * *$ \\
\hline $\begin{array}{l}\text { T3 - Negativação da } \\
\text { baciloscopia }\end{array}$ & 46,7 & 79,5 & $* * * *$ \\
\hline $\begin{array}{l}\text { T4 - Realização de teste para } \\
\text { HIV }\end{array}$ & 84,9 & 87.2 & $* * *$ \\
\hline \multicolumn{2}{|c|}{$\begin{array}{l}\text { INDICADOR SINTÉTICO DE DESEMPENHO NO } \\
\text { DLAGNÓSTICO E TRATAMENTO DA TUBERCULOSE }\end{array}$} & \multirow{2}{*}{\multicolumn{2}{|c|}{$\begin{array}{l}\text { LEGENDA: CLASSIFICAÇÃO DOS ITENS } \\
\text { NO CONJUNTO DE } 57 \text { MUNICÍPIOS }\end{array}$}} \\
\hline ITB & & & \\
\hline \multicolumn{2}{|c|}{$\ldots+\cdots \cdots \cdots+\cdots$} & $* * *$ & $\begin{array}{l}11^{\circ} \text { a } 20^{\circ} \\
21^{\circ} \text { a } 37^{\circ}\end{array}$ \\
\hline \multicolumn{2}{|c|}{$\begin{array}{l}\text { TOTAL DE CASOS NOTIFICADOS NO ANO: } 136 \\
\text { CASOS NOVOS: } 115\end{array}$} & ** & $\begin{array}{l}38^{\circ} \text { a } 47^{\circ} \\
48^{\circ} \text { a } 57^{\circ}\end{array}$ \\
\hline
\end{tabular}

Figura 7. CARTA COMPARATIVA DE AVALIAÇĀO DE DESEMPENHO NO PROGRAMA dE CONTROLE DA TUBERCULOSE dO MUNICÍPIO M5, ANO 2002

O responsável pelo município 5, ao receber este instrumento, saberá que seu município é o penúltimo classificado. Verá também que o maior problema é o resultado de tratamento, o que deve estar invalidando os resultados relativamente bons na busca e diagnóstico dos casos. Seu desempenho foi mediano na taxa de curas, o controle bacteriológico está entre os piores, idem quanto ao teste para HIV. 
Como está melhor nos quesitos busca de casos e diagnóstico, todos os esforços deverão ser dirigidos aos serviços que realizam o tratamento, porque o risco de aumento da resistência medicamentosa é grande, quando muitos casos são descobertos e não são conduzidos adequadamente à cura.

As análises aqui apresentadas a título de exemplo, é óbvio, não esgotam a questão. O papel de um indicador, como o próprio nome diz, é apontar indícios que deverão ser mais bem estudados. Somente o conhecimento local poderá responder às questões levantadas, mas parece claro que este instrumento pode suscitar e orientar o aprofundamento da análise local. 
6 Considerações finais 


\section{CONSIDERAÇÕES FINAIS}

$\mathrm{Na}$ condução dos programas de saúde, muitas vezes os municípios têm encontrado dificuldades. Quase sempre as decisões ainda são tomadas sem bases técnicas ou científicas, prevalecendo razões outras, muitas vezes relacionadas à política municipal e em detrimento da qualidade dos serviços prestados à população. O uso da epidemiologia para direcionar politicas de saúde precisa ser fortalecido e a dificuldade de acesso e interpretação dos dados é um empecilho para isso. Algumas questões importantes sobre o sistema de vigilância da tuberculose são expostos a seguir. Sendo ele um sistema de informação, cabe questionar:

\section{A quem informa?}

É absolutamente claro que este sistema, para funcionar adequadamente, precisa partir da definição de quais serão os seus principais usuários. Este ponto não pode ser tratado genericamente.

Dizer que um dos interlocutores privilegiados é o secretário municipal de saúde é vago - é preciso saber quem são esse secretários, o que os move na direção da melhoria do sistema, como percebem a situação epidemiológica. quais são os estímulos a que respondem. É comum a divulgação de dados como "a incidência no mundo é de 8 milhões de casos novos", "o Brasil é um dos países de maior carga da doença", "morrem tantas pessoas a cada minuto". O que estes dados trazem de concreto para alguém que está encarregado da saúde - não só da tuberculose - de um município de 230 mil habitantes no interior do Estado de São Paulo, e que, além das preocupações técnicas, é uma pessoa com um cargo político e, como tal, responde? 
Estas pessoas, ocupadas que são com um sem-número de atividades, precisam de instrumentos muito mais fáceis de interpretar do que os relatórios tradicionais. Uma das medidas que os impelem na direção de tomar medidas positivas é saber como estão os seus pares quanto ao desempenho nesse programa.

Quanto ao responsável pelo programa de tuberculose nesses municípios, outro usuário prioritário das informações do sistema, o mesmo raciocínio é válido. Em geral, as avaliações de programas tradicionais como o da tuberculose seguem um modelo internacional, onde se requerem dados padronizados como a taxa de curas (que tem como meta fixa atingir $85 \%$ ) e a porcentagem de casos descobertos, em relação ao estimado. O mesmo conjunto de dados referente a países como um todo não pode pedido a gestores de municípios e condensado de forma burocrática - de que vale saber qual a incidência de meningite em menores de 4 anos, a taxa de mudanças de diagnóstico, a taxa de falências do esquema de tratamento, eventos raros em municípios de porte médio?

\section{O que informa?}

É da maior importância que os sistemas de informações sejam orientados para as necessidades dos usuários. Sendo um programa de raízes bastante centralizadoras, o PCT precisa de esforço para que se fuja dos dados excessivamente agregados e estimativas idem. Saber que " no mundo ocorrem 8 milhões de casos por ano" pode ter menor impacto do que o aumento de 80 para 100 casos no município $\mathrm{X}$, quando o interlocutor é o secretário municipal de saúde: ele pouco poderá influir sobre o primeiro dado, mas será impelido a dar alguma resposta no segundo caso. $O$ diretor de um hospital, por sua vez, pode não se interessar tanto pelo aumento da 
incidência no município como por saber do tempo médio de permanência dos casos em sua instituição, e assim por diante. A prioridade deve ser, portanto, voltada para o tipo de informação necessária para decisões. Isso não é comum no $\mathrm{PCT}$, nem em outros programas. No caso da tuberculose, por exemplo, estimula-se os municípios a fixar metas de descobertas de casos, porém nenhuma metodologia que satisfaça minimamente critérios científicos é sugerida para a estimativa, dada a enorme imprecisão do instrumental disponivel.

A proposta de se utilizar o sistema de vigilância de doenças de notificação compulsória para acompanhamento de um programa de saúde pode causar alguma estranheza, já que sua finalidade original é um pouco distante da gestão do sistema de saúde. Como os outros sistemas de vigilância de doenças, ele foi concebido para retratar a situação epidemiológica do agravo tuberculose, sua tendência e fatores de risco.

Recomenda-se avaliar sistemas de vigilância de doenças com base em critérios como sensibilidade, especificidade, representatividade, simplicidade, aceitabilidade, oportunidade, utilidade, ${ }^{3,98}$ mas essa utilidade estaria voltada prioritariamente à descrição do comportamento da doença, à detecção de alterações na curva de incidência, mortalidade, etc. Em que a decisão de computar os dados por município de residência ou de atendimento afetaria a qualidade de um sistema de vigilância? Para que saber se os casos estão sendo descobertos por procura espontânea ou por busca ativa na comunidade? Para outros agravos, o registro desses dados pode ser menos importante e até certo ponto dispensável. Mas acompanhar a situação epidemiológica não exclui a avaliação e o monitoramento das medidas de 
controle da doença.

No caso da tuberculose ela é, ao contrário, necessariamente complementada pelo acompanhamento das ações do PCT. A prevalência da doença é indissociável da taxa de cura, da qualidade do tratamento, do encadeamento do processo busca/diagnóstico/tratamento. É uma falsa questão, pelo menos na atual situação do SUS, querer separar vigilância da coordenação e controle da doença, como se fosse possível pairar acima das ações do sistema de saúde para dar conta, somente, de apontar tendências e fatores de risco.

Chega-se à conclusão, portanto, que a vigilância, pelo menos no caso da tuberculose, inclui o monitoramento da qualidade do programa de controle. $\mathrm{O}$ sistema de informação não informa a entes neutros - informa a pessoas que, em maior ou menor grau, serão envolvidas na tarefa de mudar a tendência "natural" da doença, interagindo com o sistema de saúde e com a própria malha de relações sociais.

Sendo assim, o mesmo sistema de vigilância que nos diz que a incidência tende a aumentar ou a diminuir deve dar conta de apontar se, e de que maneira, o sistema de saúde está contribuindo para isso. É uma doença bastante complexa e sua vigilância já inclui um amplo leque de informações - não seria possível nem desejável que houvesse dois sistemas de informação em paralelo, um voltado para a vigilância e outro para a gestão programática.

Outra questão a ser trabalhada é a evolução do programa nos municípios. Podem ser testadas variáveis como "diferença da taxa de curas entre um ano e outro", "diferença na confirmação dos casos", informações estas que também podem orientar 
os municípios quanto às suas prioridades.

\section{Como, quando e para quê informa?}

Talvez o ponto mais importante, ao implantar novas estratégias para sistemas de vigilância epidemiológica, seja a definição das maneiras de se assegurar que as informações não só sejam incorporadas na rotina dos gestores, como também desencadeiem ações para melhorar a situação do agravo a que se destinam.

Sandiford e colaboradores ${ }^{80}$, refletindo sobre o papel dos sistemas de informação na saúde pública, aconselham que a análise e interpretação de dados seja tornada um ritual, para que seja incorporada como base para decisões. Em São Paulo, isso já vem ocorrendo na vigilância da tuberculose, e os resultados são perceptíveis. Desde 1998, a cada três ou quatro meses, tem sido realizada uma reunião de avaliação, da qual participam representantes de municípios, equipes regionais de vigilância e outros atores importantes no manejo do PCT no Estado iii.

A comparação entre os resultados alcançados pelos municípios pode levar a uma competição salutar, desde que bem conduzida. Um ponto controverso é o risco/benefício de se disponibilizar o acesso a estes dados para interessados que não os responsáveis pelo setor saúde do município avaliado. É uma decisão estratégica, pois os dados podem ser mal interpretados, levando a uma atitude defensiva dos municípios e não a decisões o sentido de melhorar seu desempenho.

\footnotetext{
iii Secretaria de Estado da Saúde de São Paulo / Centro de Vigiância Epidemiológica / Divisão de Tuberculose informação pessoal
} 
Sendo comparativos, os indicadores aqui construídos não são absolutos, precisam ser refeitos a cada avaliação. A forma de construção destes indicadores sintéticos de desempenho prevê reaferição. Como o sistema de informação é dinâmico - pode melhorar ou piorar conforme as mudanças administrativas convém testar a estabilidade da escala, por exemplo, repetindo-se o procedimento para os dados correspondentes a outros anos. Vale lembrar que um mesmo resultado pode ser avaliado de forma diferente de um ano para outro. Esta é uma escala comparativa e, se todos os municípios estiverem mal, aqueles que obtiverem um resultado um pouco melhor serão bem classificados, não importando se a qualidade de seu trabalho é suficientemente boa. Se, no ano seguinte, houver melhora do desempenho do conjunto, municípios cujos valores estiverem estacionados poderão baixar na classificação.

Uma dimensão importante do PCT - a busca de casos - não obteve consistência suficiente para ser validada. Sugere-se que sejam envidados esforços para melhorar o sistema de informação e também que sejam acrescentados dados de outras fontes, como o Sistema de Informações de Mortalidade (SIM) e o Sistema de Vigilância Laboratorial (LAB-TB). Quando ao tratamento, chama a atenção o fato de não ter sido validada a informação sobre a modalidade supervisionada, nem aquelas sobre a duração do tratamento, o que demanda uma análise mais aprofundada. É possível que alguns itens não estejam suficientemente definidos para as pessoas encarregadas de informar.

Uma das formas de melhorar a qualidade dos dados é verificar as variáveis não validadas. Embora acrescente várias dimensões não contempladas na avaliação 
tradicional do PCT, a carta de avaliação não abrange todo o leque de possíveis indicadores de desempenho do PCT. Muitas variáveis poderão ser incorporadas se a qualidade do banco de dados melhorar, por treinamentos, auditoria dos dados e algumas alterações nas fichas de notificação no sentido de minimizar a probabilidade de erros no preenchimento. Em alguns casos, o esclarecimento das causas demanda pesquisas pontuais para detectar dificuldades específicas.

Se os dados melhorarem em qualidade - e isso pode ocorrer até em decorrência de serem mais valorizados - outras variáveis poderão ser agregadas aos indicadores aqui propostos.

Uma etapa não abordada neste trabalho, porém de fundamental importância, é a legitimação dos indicadores junto a seus usuários ${ }^{2}$. Esta é condição prévia de qualquer programa de saúde - é preciso obter consenso sobre os princípios de um bom desempenho. Isso passa por treinamento e capacitação das equipes municipais e estaduais responsáveis pelo programa, pela revisão dos indicadores incorporando outras opiniões, mas também pelo convencimento dos dirigentes e a divulgação dos resultados nos meios acadêmicos, profissionais e de outros segmentos sociais. $\mathrm{O}$ nível de detalhamento, é claro, varia de acordo com o envolvimento destes e sua capacidade de percepção, mas a avaliação será tanto mais efetiva quanto melhor a apropriação dos resultados pelos interessados e o uso das informações no sentido de intervir onde for necessário.

A opção de congregar municípios com mais de 100 mil habitantes teve o intuito de possibilitar que estes instrumentos pudessem ser utilizados em avaliações anuais. Caso seja conveniente que estas ocorram mais amiúde, talvez se deva reduzir 
o número de municípios aos de população maior que $200 \mathrm{mil}$ ou $300 \mathrm{mil}$ habitantes, ou modificar o critério segundo um número mínimo de casos notificados, de forma a garantir menor interferência do acaso nos resultados da avaliação.

É óbvio que, mesmo assim, grande parte desses dados pode não ser significativa, nos municípios com menor incidência. Porém, dado que o objetivo deste instrumento é principalmente o monitoramento do desempenho e tendo em vista que a carta inclui a totalidade dos casos notificados no periodo, pode-se admitir um prejuizo da significância em função dos benefícios práticos advindos da inclusão de um número maior de municípios.

\section{Sugestões para o sistema de vigilância estadual e novas}

\section{pesquisas em avaliação do $\mathrm{PCT}$}

Algumas questões levantadas durante a realização deste estudo puderam ser endereçadas à coordenação estadual do PCT. Entre elas, citem-se certos quesitos sobre a descoberta dos casos, que precisariam ser melhor trabalhados para propiciar a validação da avaliação da busca de casos.

No desenho deste trabalho, ficou claro que há necessidade de se construir novas formas de abordagem para problemas específicos. Não seria adequado, por exemplo, incluir a capital do Estado no rol de municípios analisados desta forma: a condução do PCT em um município como São Paulo demanda uma estratégia própria, desagregando os dados por regiões, avaliando em separado grandes hospitais, serviços universitários, grupos populacionais como os moradores de rua, grandes presídios, toda uma série de condições particulares e complexas. Para os 
municípios de menos de 100 mil habitantes, que também não poderiam ser incluídos nesta proposta, talvez se beneficiassem de estratégias como a investigação de eventos-sentinela (óbitos, casos resistentes, meningo-tuberculoses, etc.). Grupos populacionais como os detentos, por sua vez, precisam de outro tipo de avaliação, tendo como uma das prioridades estreitar as comunicações entre o sistema de saúde e o sistema prisional, para monitorar as transferências de presídios, por exemplo.

$\mathrm{O}$ modelo de avaliação e monitoramento aqui proposto não esgota o espectro de possibilidades de atuação do sistema para embasar decisões. Por exemplo: é claro que, se levarmos em conta a duração mínima de 6 meses do tratamento, há necessariamente um hiato até que se possa analisar os resultados. Mas as medidas corretivas precisam ser mais imediatas. Uma informação preciosa no sistema de informação EPI-TB é o acompanhamento mensal da situação de tratamento. Um indicador possível seria a taxa de abandonos de tratamento antes do terceiro mês. Com isso, seria possivel ganhar em oportunidade, mesmo que a informação não fosse tão completa. 
7 Conclusões 


\section{CONCLUSÕES}

- O sistema EPI-TB de vigilância da tuberculose pode fornecer informações suficientes para avaliação e monitoramento do PCT.

- Com dados desse sistema foi possivel construir um indicador sintético escalar para o desempenho dos municípios no PCT.

- Neste trabalho, foram construídos instrumentos passíveis de aplicação imediata para mudança na estratégia de avaliação e monitoramento do desempenho dos municípios no Programa de Controle da Tuberculose, diminuindo o grau de subjetividade nessa tarefa.

- Esta análise poderá ser feita periodicamente, em intervalo a ser definido, sem nenhum ônus para os municipios ou os níveis estadual ou federal de coordenação do PCT, motivando os municipios a alcançarem melhores resultados quanto ao controle da tuberculose.

- Para avaliação sintética do desempenho no PCT, as variáveis incluídas foram: realização de baciloscopia de escarro para casos de tuberculose pulmonar em adultos, confirmação bacteriológica dos casos pulmonares, realização de pelo menos duas baciloscopias de controle para os casos inicialmente baciliferos, obtenção de pelo menos uma baciloscopia negativa nesses casos, realização de teste para HIV e uma variável aqui denominada razão de adesão, construída com base na relação entes curas e abandonos de tratamento.

- Na construção de indicadores parciais de desempenho na busca de casos, 
diagnóstico e tratamento, a análise de confiabilidade sugere que há mais consistência nos dados referentes à qualidade do diagnóstico. No quesito tratamento, a confiabilidade ainda foi aceitável, considerando-se o fato de serem obtidos de um sistema da rotina de vigilância. No aspecto busca de casos, os itens analisados não forneceram um retrato suficientemente confiável para avaliação da qualidade; poderse-ia dizer que aproximadamente a metade da real dimensão da qualidade da descoberta de casos pode ser retratada pelas variáveis "demora entre o inicio dos sintomas e a instituição do tratamento" e "porcentagem de casos descobertos por busca de sintomáticos respiratórios".

- A computação dos dados segundo municipio de atendimento foi mais consistente que aquela feita por município de residência - isso sugere que os municipios se responsabilizam melhor quando os pacientes são atendidos pelos seus serviços de saúde, mesmo que residam fora do município, do que pelos seus próprios munícipes, quando atendidos por outros municipios.

- A análise de agrupamentos de municípios segundo desempenho no PCT facilita a detecção de problemas e priorização de medidas de apoio e correção nos âmbitos regional, estadual e federal.

- As cartas gráficas de desempenho dos municipios no PCT, por sua facilidade de compreensão e por não exigirem alterações de fluxos e impressos, podem ser úteis na rotina de gestão do programa em âmbito municipal e, para as outras esferas, como instrumento de supervisão indireta.

- A metodologia aqui desenvolvida poderá ser útil na avaliação e monitoramento de outros programas de saúde. 
8. BIBLIOGRAFIA 
1. $[\mathrm{CDC}]$ Centers for Disease Control and Prevention. Epidemiologic Notes and Reports Expanded Tuberculosis Surveillance and Tuberculosis Morbidity - United States, 1993. MMWR Morb Mortal Wkly Rep 1993; 43(20): 361-366.

2. $[\mathrm{CDC}]$ Centers for Disease Control and Prevention. Framework for Program Evaluation in Public Health. MMWR Morb Mort Wkly Rep 199948 (RR11); 1-40.

3. $[\mathrm{CDC}]$ Centers for Disease Control and Prevention. Guidelines for evaluating surveillance systems. MMWR Morb Mort Wkly Rep 1988; 37(SS-5):1-18.

4. [CDC] Centers for Disease Control. A strategic plan for the elimination of tuberculosis in the United States. MMWR Morb Mort Wkly Rep 1989; 38:269-72.

5. Almeida ES. Políticas públidcas e organização do sistema de saúde: antecedentes, reforma sanitária e o SUS. In:Gestão dos serviços de saúde: descentralização/municipalização do SUS. Westfal MF. São Paulo, 2001. EDUSP. p.13-49.

6. Almeida M M M B, Nogueira P A, Belluomini M, Aranttes G R. Avaliação longitudinal do tratamento da tuberculose. Bol Pneum Sanit 1995; 3(1): 78-87.

7. Arantes GR, Nogueira PA, Almeida MMMB, Nassar J, Beluomini M, Lima MM, Weiler RMG. Avaliação do nível local sem prefixação de metas: experiência com a tuberculose em São Paulo. Anais do IV Congresso Paulista de Saúde Pública. Associação Paulista de Saúde Pública, 1993. Res.66.

8. Andueza Orduna J, Pérez Trullén A, Moreno Iribas C. Estudio de las características clínicas de la tuberculosis respiratoria y su demora diagnóstica. Aten Primaria 2000;26(1):26-9.

9. Arantes GR, Almeida MMB, Nogueira PA, Belluomini M, Lima MM, Nassar J. Monitorização das Açб̃es Anti-tuberculose: Implantação de uma Sistemática Experimental em São Paulo Brasil Bol Peum Sanit 1995; 3 (2):10-23.

10. Arantes GR, Beluomini M, Almeida MMB, Lima MM. Monitorização das ações antituberculose: cartas gráficas baseadas em unidades desvio padrão e tabela de classificação baseada em medidasíntese. Medicina, Ribeirão Preto 1997; 30:243-58

11 Arantes GR, Nogueira PA, Almeida MMMB, Nassar J, Beluomini M, Lima MM, Weiler RMG. Avaliação do nível local sem prefixação de metas: experiência com a tuberculose em São Paulo. Anais do IV Congresso Paulista de Saúde Pública. Associação Paulista de Saúde Pública, 1993. Res.66.

12 Borgdorff MW, Floyd K, Boekmans JF Interventions to reduce tuberculosis mortality and transmission in low-and middle-income countries. Bull World Health Org 2002; 80(3): 217-27.

13 Brook, RH, McGlynn EA, Shekelle, PG. Defining and measuring quality of care: a perspective from US researchsers. Qual Saf Health Care 2002;11:125-30.

14 Campbell SM, Braspenning J, Hutchinson A, Marshall M N. Reseach methods used in developing and applying quality indicators in primary care. M J 2003; 326:816-9.

15 Centers for Disease Control, World Health Organization. Epi Info. Epidemiologia em microcomputadores: um sistema de processamento de texto, banco de dados e estatísticas [programa de computador]. Atlanta: OPAS/WHO;1990.

16 Chaulk CP, Kazandjian VA. Directly observed therapy for treatment completion of pulmonary tuberculosis: consensus statement of then public health tuberculosis guideline panel. JAMA 1998; 279(12):943-8.

17 Coker R. Lessons from New York's tuberculosis epidemic: tuberculosis is a political as much as a medical problem - and so are the solutions. BMJ 1998; 317(7159): 616.

18 Creek TL, Lockman S, Kenyon TA, Makhoa M, Chimidza N, Moeti T, Sarpong BB, Binkin NJ, Tappero JW. Completeness and timeliness of treatment initiation after laboratory diagnosis of tuberculosis in Gaborone, Botswana. Int J Tuberc Lung Dis 2000; 4(10):956-61.

19 Dalcolmo MP, Kritski AL. Associação da tuberculose e infecção pelo HIV. J Pneumol 1993; 19:63-72. 
20 Dalcolmo MP. Regime de curta duração, intermitente e parcialmente supervisionado, como estratégia de redução do abandono no tratamento da tuberculose no Brasil. São Paulo; 2000. [Tese de doutorado. Universidade Federal de São Paulo].

21 De Cock KM, Chaisson RE. Will DOTS do it? A reappraisal of tuberculosis control in countries with high rates of HIV infection. Int J Tuberc Lung Dis 1999; 3(6): 457-65.

22 Diagnóstico y tratamiento de la tuberculosis en España: resultados del Proyecto Multicéntrico de Investigación en Tuberculosis (PMIT). Med Clin (Barc) 2001; 116(5):167-73.

23 Donabedian A. . The Quality of Care: How Can It Be Assessed? JAMA 1998; 260:1743-1748.

24 Duarte JES. Avanços e desafios do SUS: o papel do município e da academia. Saúde Soc 2002; 11(1):37-52.

25 Dye C. Tuberculosis 2000-2010: control, but not elimination. Int J Tuberc Lung Dis 2000; 4 (12 Suppl 2): S146-52.

26 Dye C; Scheele S; Dolin P; Pathania V; Raviglione MC.Consensus statement. Global burden of tuberculosis: estimated incidence, prevalence, and mortality by country. JAMA; 282(7):677-86, 1999.

27 Enarson DA. Resistance to antituberculosis medications: hard lessons to learn. Comentários: Arch Intern Med 2000;160(5):630-6. Arch Intern Med; 160(5):581-2.

28 Espinal MA, Kim SJ, Suarez PG, Kam KM, Khomenko AG, Migliori GB, BaE9z J, Kochi A, Dye C, Raviglione MC. Standard short-course chemotherapy for drug-resistant tuberculosis: treatment outcomes in 6 countries. Comentários: JAMA 2000 May 17;283(19):2575-6 Fonte: JAMA; 283(19):2537-45, 2000 May 17.

29 Fauman MA. Quality assurance monitoring in psychiatry. Am J Psych 1989; 146: 1121-30.

30 Frieden, TR, Driver, $C$. Tuberculosis control: past ten years and future progress. Tuberculosis, 2003, 83(1-3): 82-5.

31 Fundação Nacional de Saúde. Plano Nacional de Controle da Tuberculose. Brasília: Ministério da Saúde/FUNASA; 1999.

32 Galesi VMN, Santos LAR. A tuberculose no Estado de São Paulo e a estratégia de municípios prioritários. In: Anais do IV Congresso Brasileiro de Epidemiologia; 1998 ago 01-05; Rio de Janeiro, (BR). 1998. CC71-240. p.102.

33 Gordin F. Tuberculosis control: Back to the future? J Am Med Ass 1992; 267:2649-50.

34 Grzybowski S. A proposito de la historia natural de la tuberculosis. Bol Unión Int Tuberc Enf Resp 1991;66:213-14.

35 Hopewell P C. "The cure": Organization and administration of therapy for tuberculosis. In: Tuberculosis: Back to the future. Porter J H D, McAdam KPWJ, 1994. John Wiley, Sons Ltd.P.101-21.

36 Instituto Brasileiro de Geografia e Estatística. [online] Disponível em <URL: htpp://www.ibge.gov.br.

37 Johansson E, Long NH, Diwan VK, Winkvist A. Gender and tuberculosis control: perspectives on health seeking behaviour among men and women in Vietnam. Health Policy 2000; 52(1):3351

38 KiaNoury D, Timpone J, Yeager H. Can administration of a fluoroquinolone delay diagnosis of pulmonary tuberculosis? [Letter] Int J Tuberc Lung Dis 2000; 4(11):1092.

39 Melchior R. Avaliação da Organização da Assistência ambulatorial a pessoas vivendo com HIV/Aids no Brasil: Análise de 322 serviços em 7 Estados brasileiros (CE, MA, MS, PA, RJ, RS, SP). São Paulo, 2003. [Tese de doutoramento - Faculdade de Saúde Pública DA Universidade de São Paulo].

40 Ministério da Saúde. CNCT/NUTES. Controle da tuberculose: Uma proposta de integração maimo anming Dmonilin /nEI. 10nA 
ensino-serviço. Brasília (DF); 1994.

41 Ministério da Saúde. Coordenação Nacional de Pneumologia Sanitária - CENEPI - FNS - MS / Sociedade brasileira de Tisiologia e Pneumologia. I Consenso Brasileiro de Tuberculose [Capitulo 1 - Diagnóstico]. Brasilia - DF; 1997. J Pneumol 1997; 23 (6): 294-301.

42 Ministério da Saúde. Coordenação Nacional de Pneumologia Sanitária - CENEPI - FNS - MS / Sociedade brasileira de Tisiologia e Pneumologia. I Consenso Brasileiro de Tuberculose [Capítulo 1 - Diagnóstico]. Brasília - DF; 1997. J Pneumol 1997; 23 (6): 294-301.

43 Ministério da Saúde. Coordenação Nacional de Pneumologia Sanitária - CENEPI - FNS - MS / Sociedade brasileira de Tisiologia e Pneumologia. I Consenso Brasileiro de Tuberculose [Capítulo 1 - Diagnóstico]. Brasilia - DF; 1997. J Pneumol 1997; 23 (6): 294-301.

44 Ministério da Saúde. Fundação Nacional de Saúde. Centro de Referência Professor Héli Fraga. Sociedade Brasileira de Tisiologia e Pneumologia. Controle da tuberculose: uma proposta de integração ensino-serviço. $5^{a}$ ed.- Rio de Janeiro: FUNASA/CRPHF/SBPT, 2000.236 p.

45 Ministério da Saúde. Fundação Nacional de Saúde. Plano Nacional de Controle da Tuberculose. Brasilia: MS/FUNASA; 1999.

46 Ministério da Saúde. Fundação Nacional de Saúde. Plano Nacional de Mobilização e Intensificação das Açōes para eliminação da Hanseníase e Controle da Tuberculose. Brasilia: MS/FUNASA; 1999.

47 Ministério da Saúde. Portaria 1882/GM.MS (16/12/97).Reunião de Avaliação Operacional e Epidemiológica do Programa Nacional de Controle da Tuberculose na Década de 80: Documento Básico. Bol Pneum Sanit 1993; (No esp): 1-90.

48 Ministério da Saúde. Portarias No 1882/GM, de 18/12/1997 e No 993, de 04/09/2000.

49 Moore-Gillon J.Multidrug-resistant tuberculosis: this is the cost.:Ann N Y Acad Sci 2001; 953:233-40.

50 Murray CJ, Styblo K, Rouillon A. Tuberculosis in developing countries: burden, intervention and cost. Bull Int Union Tuberc Lung Dis 1990; 65: 6-24.

51 Murray CLJ, Dejonghe E, Chum HJ, Nyangulu DS, Salomao A, Styblo K. Cost effectiveness of chemotherapy for pulmonary tuberculosis in three sub-Saharian African countries. Lancet 1991; 338:1305-8.

52 Nakashima H. Tuberculosis: a global emergency. World Health 1993; 4:3.

53 Natal, S, Elias, MV Projeto de Análise de Informação para Tuberculose. Bol Peumol Sanit $2000 ; 8(1): 15-22$.

54 Needham DM, Foster SD, Tomlinson G, Godfrey-Faussett P. Socio-economic, gender and health services factors affecting diagnostic delay for tuberculosis patients in urban Zambia. Trop Med Int Health 2001; 6(4):256-9.

55 Nemes MIB, Castanheira HR, Capozzolo AD , Melchior R. Utilização de multimétodos na avaliação de programas e serviços de saúde. Ciência e Saude Coletiva 2000;5(supl): 187.

56 Netto EM, Dye C, Raviglione MC. Progress in global tuberculosis control 1995-1996, with emphasis on 22 high-incidence countries. Global Monitoring and Surveillance Project. Int $\mathbf{J}$ Tuberc Lung Dis 1999; 3(4):310-20.

57 Ngamvithayapong J, Winkvist A, Diwan V. High AIDS awareness may cause tuberculosis patient delay: results from an HIV epidemic area, Thailand. AIDS 2000; 14(10):1413-9.

58 Ngamvithayapong J, Yanai H, Winkvist A, Diwan V. Health seeking behaviour and diagnosis for pulmonary tuberculosis in an HIV-epidemic mountainous area of Thailand. Int $\mathbf{J}$ Tuberc Lung Dis 2001; 5(11):1013-20.

59 Nogueira PA, Marlucelli MIC, Abrahão RMCM, *\& Almeida MMMB. Avaliação das informações de tuberculose (1989-1999) de um Centro de Saúde-Escola da cidade de São Paulo.

Rev Bras Epidemiol 2001;4(2):131-8. 
60 Norussis M. SPSS for windows: Base system user's guide: Release 6.0 [programa de computador] SPSS Inc, Chicago; 1993.

61 Novaes. HMD Epidemiologia e avaliação em serviços de atenção médica: novas tendências de pesquisa. Cad Saude Publ 1996; 12(supl 2):7-12.

62 Novaes, HMD. Avaliação de programas, serviços e tecnologias em saúde. Cad Saude Publ $2000 ; 34: 5$.

63 Nunn, $P$ et al. The research agenda for improving health policy, systems performance, and service delivery for tuberculosis control: a WHO perspective. Bull World Health Org 2002; 80(6):

64 O’Dwyer GC, Leite MACA. Pesquisa em avaliação da atenção básica: a necessária complementação do monitoramento. Divulgação Saúde em Debate 2000; (21)29-35.

65 Oliveira HB. Reingressantes no sistema de notificação da tuberculose: Estudo das irregularidades em tratamento anterior. In: Anais do IV Congresso Brasileiro de Epidemiologia; 1998 ago 0105; Rio de Janeiro, (BR). 1998. CC71-239. p.101.

66 Oyefeso A, Clancy C, Ghodse H. Developing a quality care index for outpatient methadone treatment programmmes. J Eval Clin Pract 1998; 4(1): 39-47.

67 Pablos-Mendez, A.; Gowda, D.K., Frieden, T.R. Controlling multi-drug resistant tuberculosis and acess to expensive drugs: a rational framework. Bull World Health Org, 2002; 80(6):48995. Discussion 495-500.

68 Paes de Barros R, Carvalho M, Franco S. O índice de desenvolvimento da família - texto para discussão No 986 - ISSN 1415-4675 Rio de janeiro, out 2003 [mimeo]

69 Penna MLF. Uma abordagem ecológica da tuberculose. Cad Saude Publ 1998; 4:356-62.

70 Penna, MLF. Tuberculose: assistência ou controle? Bol CNCT 1988; 2: 5-25.

71 Penna, MLF. Tuberculose: assistência ou controle? Bol CNCT 1988; 2: 5-25.

72 Pereira JCR. Análide de dados qualitativos: estratégias metodológicas para as ciências da saúde, humanas e sociais. 3a.ed. - São Paulo: Editora da Universidade de São Paulo. Processamento e análise de variáveis qualitativas; p. $77-100$.

73 Pereira JCR. Análide de dados qualitativos: estratégias metodológicas para as ciências da saúde, humanas e sociais. 3a.ed. - São Paulo: Editora da Universidade de São Paulo. Processamento e análise de variáveis qualitativas; p. $77-100$.

74 Pio A. Impact of present control methods on the problem of tuberculosis. Rev Infect Dis 1989; 2[Suppl 2]: S360-5.

75 Reichman LB. The U-shaped courve concern. Am Rev Resp Dis 1991;144:741-2.

76 Rodrigues LC, Smith PG. Tuberculosis in developing countries and methods for its control. Trans R Soc Trop Med Hyg 1990; 84(5):739-44.

77 Rouillon A, Perdrizet S, Parrot T. Metodos de Control de la tuberculosis. Publ. Cient.OPS, Washington 1977; 346:1-30.

78 Ruffino-Netto A. Impacto da reforma do setor saúde sobre os serviços de tuberculose no Brasil. Bol Pneum Sanit 1999; 7 (10): 7-18.

79 Salaniponi FM, Harries AD, Banda HT, Kang'ombe C, Mphasa N, Mwale A, Upindi B, Nyirenda TE, Banerjee A, Boeree MJ. Care seeking behaviour and diagnostic processes in patients with smear-positive pulmonary tuberculosis in Malawi. Int $\mathbf{J}$ Tuberc Lung Dis 2000; 4(4):327-32.

80 Sandiford $\mathrm{P}$, Annett $\mathrm{H}$, Cisbulskis $\mathrm{R}$. What can information systems do for primary health care? An international perspective. Soc Sci Med 1992; 34 (10): 1077-87.

81 Santos LAR, Almeida MMMB, Arantes GR, Nogueira PA, Beluomini M, Lima MM, Nassar J. Avaliação de serviços com base na técnica de percentis: experiência com a tuberculose em São 
Paulo. Anais do IV Congresso Paulista de Saúde Pública. Associação Paulista de Saúde Pública, 1993. Res.180.

82 Santos LAR, Araújo LB. Sistema informatizado para análise e gerenciamento em tuberculose: O EPI-TB. In: Anais do IV Congresso Brasileiro de Epidemiologia; 1998 ago 01-05; Rio de Janeiro, (BR). 1998. res 0088. p.163.

83 Santos LAR, Galesi VMN. Treinamento Básico em Vigilância Epidemiológica - módulo específico Tuberculose. Centro de Vigilância Epidemiológica "Professor Alexandre Vranjac" Secretaria de Estado da Saúde SP, 2000 [online] disponível em www/cve/saude/sp/gov/br.

84 Santos LAR, Galesi VMN. Uso de critério epidemiológico para priorização em saúde: A tuberculose como doença dos centros urbanos. In: Anais do IV Congresso Brasileiro de Epidemiologia; 1998 ago 01-05; Rio de Janeiro, (BR). 1998. res 0172. p.191.

85 Sherman LF, Fujiwara PI, Cook SV, Bazerman LB, Frieden TR. Patient and health care system delays in the diagnosis and treatment of tuberculosis. Int $\mathbf{J}$ Tuberc Lung Dis 1999; 3(12):108895.

86 Shimao T et al. Tuberculosis surveillance at health center level. TSRU Prograss Report 1978; 1:1-10. citado por Arantes GR, Beluomini M, Almeida MMB, Lima MM. Monitorização das ações antituberculose: cartas gráficas baseadas em unidades desvio padrão e tabela de classificação baseada em medida-síntese. Medicina, Ribeirão Preto 1997; 30:243-58.

87 Soares ACG. Avaliação epidemiológica e do Programa de Controle da Tuberculose no Município de Taboão da Serra, São Paulo, 1994 a 1998. São Paulo, 2001. [Dissertação de mestrado - Faculdade de Saúde Pública da Universidade de São Paulo].

88 Styblo K. Epidemiology of tuberculosis. The Hague, Royal Netherlands Tuberculosis Association 1991c. p.10-115 [Selected Papers, 24].

89 Tanaka OY, Nemes MIB, Novaes HMD, Bastos MG, Riedel F, Rosalen J. Formação de gestores locais de saúde: processo para identificar áreas de atuação. Rev Saude Publ 1999; 33 (30):21929.

90 Tanaka,OY, Melo,C. Avaliação de Programas de Saúde do Adolescente: um modo de fazer. São Paulo, 2001. Editora da Universidade de São Paulo.

91 The Global Found Against Aids, Tuberculosis and Malaria. [www.theglobalfound.org ]

92 The World Bank. World developement report 1993: Investing in health. New York (NY): Oxford University Press, 1993.

93 Thorson A, Hoa NP, Long NH. Health-seeking behaviour of individuals with a cough of more than 3 weeks. Comment In:Lancet 2001; May 12;357(9267):1532-3 Lancet 2000; 356(9244):1823-4.

94 Toman K. Tuberculosis case-finding and chemotherapy: Questions and answers. Geneva, Switzerland, World Health Organization 1999. p. 14-22: How reliable is chest radiography?

95 Toman K. Tuberculosis case-finding and chemotherapy: Questions and answers. Geneva, Switzerland, World Health Organization 1999. p. 14-22: How reliable is chest radiography?

96 Tmka L, Danková D. How to improve validity of notified data in tuberculosis surveillance system. Tuberc Lung Dis 1994; 75(supl 1):80.

96 Trnka L, Danková D. How to improve validity of notified data in tuberculosis surveillance system. Tuberc Lung Dis 1994; 75(supl 1):80.

97 Volmink J, Gamer P. Directly observed therapy for treating tuberculosis (Cochrene review). In: The Cochrane Library, Issue 2, 2003. Oxford: Update software.

98 Waldman EA. Vigilância epidemiológica como prática de saúde pública. São Paulo, 1991. [Tese de doutorado - Faculdade de Saúde Públida da Universidade de São Paulo].

98 World Health Organization. Global Tuberculosis Control: Surveillance, Planning, Financing. WHO Report 2003.Geneva, Switzerland (WHO/CDS/TB/2003.316). 
Anexo 1. Municípios do Estado de São Paulo com população de mais de 100 mil habitantes em 2002 e respectivos totais de casos de tuberculose notificados nesse ano

\begin{tabular}{|c|c|c|}
\hline MUNICÍPIO & POPULACุÃO 2002 & TOTAL DE CASOS NOTIFICADOS \\
\hline M1 & 188643 & 59 \\
\hline $\mathrm{M} 2$ & 172768 & 70 \\
\hline M3 & 187363 & 67 \\
\hline M4 & 116553 & 34 \\
\hline M5 & 105701 & 25 \\
\hline M6 & 224584 & 150 \\
\hline M7 & 327626 & 126 \\
\hline M8 & 111998 & 22 \\
\hline M9 & 130323 & 83 \\
\hline M10 & 357417 & 265 \\
\hline M11 & 109017 & 40 \\
\hline $\mathrm{M} 12$ & 157726 & 97 \\
\hline M13 & 111922 & 147 \\
\hline M14 & 367958 & 198 \\
\hline M15 & 218535 & 131 \\
\hline M16 & 152100 & 118 \\
\hline M17 & 299233 & 88 \\
\hline M18 & 144227 & 65 \\
\hline M19 & 112874 & 105 \\
\hline $\mathrm{M} 20$ & 106722 & 40 \\
\hline M21 & 276301 & 372 \\
\hline M22 & 1132651 & 535 \\
\hline M23 & 166549 & 48 \\
\hline M24 & 156750 & 60 \\
\hline M25 & 138952 & 70 \\
\hline M26 & 130552 & 60 \\
\hline M27 & 173891 & 189 \\
\hline M28 & 295663 & 172 \\
\hline M29 & 141268 & 57 \\
\hline M30 & 197061 & 75 \\
\hline M31 & 115889 & 29 \\
\hline M32 & 330578 & 162 \\
\hline M33 & 204957 & 58 \\
\hline M34 & 377782 & 157 \\
\hline M35 & 342248 & 191 \\
\hline M36 & 129162 & 44 \\
\hline M37 & 670345 & 548 \\
\hline M38 & 131068 & 52 \\
\hline M39 & 339772 & 111 \\
\hline M40 & 208329 & 220 \\
\hline M41 & 194173 & 98 \\
\hline M42 & 108595 & 25 \\
\hline M43 & 520502 & 219 \\
\hline M44 & 175299 & 48 \\
\hline M45 & 656136 & 260 \\
\hline M46 & 418095 & 525 \\
\hline M47 & 731852 & 282 \\
\hline M48 & 138190 & 54 \\
\hline$M 49$ & 200315 & 48 \\
\hline M50 & 374745 & 137 \\
\hline M51 & 559710 & 258 \\
\hline M52 & 310901 & 423 \\
\hline M53 & 517551 & 244 \\
\hline M54 & 208445 & 49 \\
\hline M55 & 243387 & 151 \\
\hline M56 & 205547 & 150 \\
\hline M57 & 251992 & 70 \\
\hline
\end{tabular}


SECRETARIA DE ESTADO DA SAÚDE COORDENAÇÃO DOS INSTITUTOS DE PESQUISA

CENTRO DE VIGILÂNCIA EPIDEMIOLÓGICA

FICHA DE NOTIFICAÇÃO DE TUBERCULOSE

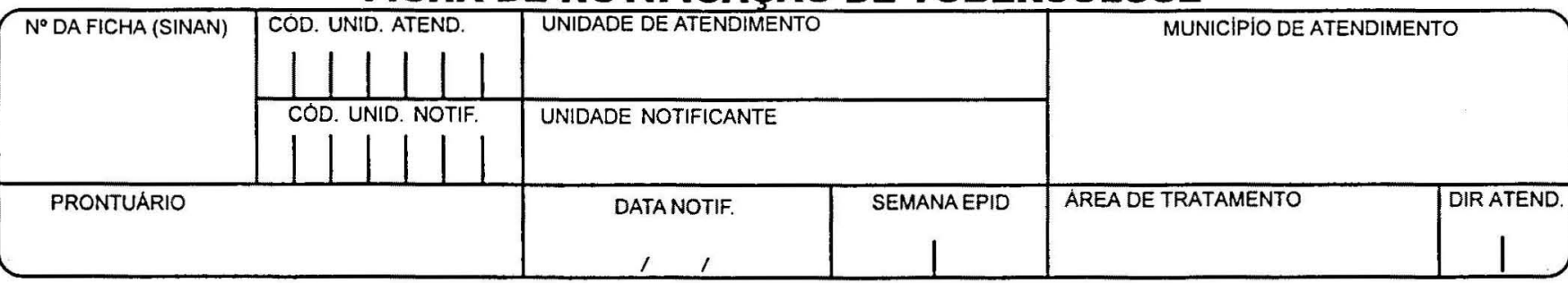

\section{IDENTIFICAÇÃO}

NOME

\begin{tabular}{|c|l|l|l|}
\hline DATA DE NASCIMENTO & SEADE (anos completos) & \\
\hline
\end{tabular}

MÃE

BAIRRO

MUNICIPIO RESIDÉNCIA

TIPO DE OCUPAÇAO

1.PROFISSIONALDE SAUDE

2. PROFISSIONAL SISTEMA PENITENCIARIO

6. DETENTO

3.DESEMPREGADO

(DDD) TELEFONE

4. APOSENTADO

5. DONADE CASA

FORMA CLÍNICA

TRATAMENTO ANTERIOR (O ÚLTIMO ANTES DO ATUAL)

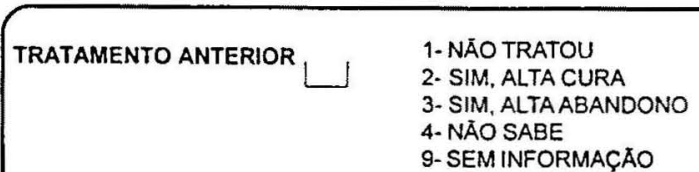

SE SIM, TRATOU HÁ

O1-PULMONAR
O3-MENINGITE
O4-PLEURAL
05- GANGLIONAR PERIFERICA
O6- OSSEA
07-VIAS URINARIAS
08-GENITAL
09-INSTESTINAL

10-OFTÁLMICA

11. PELE

13- LARINGE

15- MILIAR

16- OUTRAS

17- DISSEMINADA

99. SEM INFORMAÇÃO

\section{DESCOBERTA}

\section{TIPO DE DESCOBERTA}

$\longrightarrow$

-APRESENTAÇÃO ESPONTȦNEA COM SINTOMAS RESPIRATORIOS

2- APRESENTACCAOO ESPONTÁNEA POR OUTROS MOTIVOS

- ENCAMINHADO COM SUSPEITA OU DIAGNÓSTICO DE TB

RECEBIDODE

4. CONTROLE DE COMUNICANTES

5-DESCOBERTO APÓS OBITO

\section{SERVIÇO QUE}

DESCOBRIU O CASO: L L L L

CÓDIGOS:

01- AMBULLATOR! 2 PÚBLICO

02. AMBULATORI, UNIVERSITÁRIO

03- AMBULATÓRIO PRIVADO

04-P.S. OU HOSPITAL PÜBLICO

05- P.S. OU HOSPITAL UNIVERSITARIO

06- P.S. OU HOSPITAL PRIVADO

TEMPO DECORRIDO DO INICIO

DOS SINTOMAS AO TRATAMENTO: - LلـالـLMANAS
07-DESCOBERTO PORATESTADO DE OBITO 08- MÉDICO PARTICULAR

09- DESCOBERTO PIFICHA DE AIDS

10- DESCOBERTO PIFICHA DE MENINGITE 11-OUTRO

99-SEM INFORMAÇÄO

\section{EXAMES COMPLEMENTARES PARA DIAGNÓSTICO}

\section{BACTERIOLOGIA: \\ $\checkmark$ BACILOSCOPIA DE ESCARRO \\ $\checkmark$ BACILOSCOPIA OUTRO MATERIAL \\ $\amalg$ CULTURA DE ESCARRO \\ $L$ JCULTURA OUTRO MATERIAL}

CÓDIGOS:
1-POSITIVO
2- NEGATIVO
3- EM ANDAMENTO
8- NẢO-REALIZADO
9- SEM INFORMAÇĀO

IESPECIFICAR:
OUTROS EXAMES:

$\lfloor$ RXDETORAX $\amalg$ RXOUTRO

CÓDIGOSRX:

1- NORMAL

2- SUSPEITA DE TB

3- SUSPEITA DE TB COM CAVERNA

4- OUTRAS AFECÇOES

8- NÃO-REALIZADO

9. SEM INFORMACÃO $\perp$ HISTOPATOLOGICO I I NECROPSIA

CÓDIGOS HISTOPAT. E NECRÓPSIA:

1- SUGESTIVO DE TB

2-NÃO-SUGESTIVO TE

8- NÃO-REALIZADO

9- SEM INFORMAÇĀO

DOENÇAS ASSOCIADAS

\begin{tabular}{|c|c|c|c|c|}
\hline $\begin{array}{l}L \\
L\end{array}$ & $\begin{array}{ll}\text { CÓDIGOS: } & \text { 5-OUTRA } \\
\text { 1-AIDS } & \text { 6- NENHUMA } \\
\text { 2-DIABETES } & \text { 9-SEMINFORMAÇĀO } \\
\text { 3-ALCOOLISMO } & \\
\text { 4-DOENÇAMENTAL } & \end{array}$ & $\sqcup$ ANTI-HIV & $\begin{array}{l}\text { CODIGOS: } \\
\text { 1-POSITIVO } \\
\text { 2-NEGATIVO }\end{array}$ & $\begin{array}{l}\text { 3- EM ANDAMENTO } \\
\text { 8- NÃO-REALIZADO } \\
\text { 9- SEM INFORMAÇAOO }\end{array}$ \\
\hline
\end{tabular}


TRATAMENTO ATUAL

\begin{tabular}{|c|c|c|}
\hline$\cdots$ & & DROGAS NO INICIO DO TRATAMENTO: 1-SIM 2-NÃO \\
\hline DATA DE INICIO: & CÓDIGOS: & ) \\
\hline ITIPO DE TRATAMENTO & 1- AUTO ADMINISTRADO & JRIFAMISICINA (R) \\
\hline LTIPO DE TRATAMENIO & $\begin{array}{l}\text { 2- SUPERVISIONADO } \\
\text { 9-SEM INFORMAÇAOO }\end{array}$ & $\sqcup$ IZONIAZIDA (H) \\
\hline & & L ESTREPTOMICINA (S) \\
\hline
\end{tabular}

CONTATOS DOMICILIARES

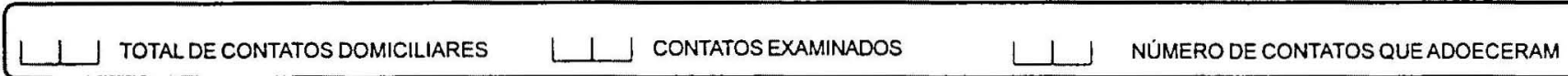

INTERNAÇÃo

\begin{tabular}{|c|c|c|c|c|c|c|}
\hline \multicolumn{4}{|l|}{ HOSPITAL } & \multicolumn{3}{|c|}{ DATADA INTERNAÇĀO } \\
\hline MOTIVOPRINCIPAL & $\begin{array}{l}\text { CÓDIGOS: } \\
\text { 01- INSUFICIENNCIA RESPIRATORIA } \\
\text { O2-HEMOPTISE } \\
\text { 03- MENINGITE }\end{array}$ & $\begin{array}{l}\text { 04- MILIAR } \\
\text { 05-ABSCESSO } \\
\text { O6-AIDS } \\
\text { 07-DIABETES }\end{array}$ & \multicolumn{2}{|c|}{$\begin{array}{l}\text { 08- INTOLERÃNCIA MEDICAM. } \\
\text { O9-CAQUEXIA } \\
\text { 10-ELUCIDAÇĀO DIAGNOSTICA } \\
\text { 11- CAUSAS SOCIAIS }\end{array}$} & \multicolumn{2}{|c|}{$\begin{array}{l}\text { 12- OUTROS } \\
\text { 14- NAO ADESAO } \\
\text { AOTRATAMENTO } \\
\text { 99- SEM INFORMAÇAO }\end{array}$} \\
\hline$\cdots$ & & & & \multicolumn{3}{|c|}{ DATA DA ALTA HOSPITALAR } \\
\hline $\begin{array}{ll}\longleftarrow \_\_ \text {TIPODE } \\
\text { SAIDAHOSPITALAR }\end{array}$ & $\begin{array}{l}\text { CÓDIGOS: } \\
\text { O1- CURA } \\
\text { O2- A PEDIDO } \\
\text { 03- DISCIPLINAR }\end{array}$ & $\begin{array}{l}\text { JDANÇA DE DIAGA } \\
\text { TAPITRATAMENTC } \\
\text { ANSFERENCIA DE } \\
\text { ITO POR TB }\end{array}$ & $\begin{array}{l}\text { STICO } \\
\text { MBULATORIAL } \\
\text { HOSPITAL }\end{array}$ & $\begin{array}{l}\text { 08- OBIT } \\
\text { O9-EVAD } \\
\text { 10- OBIT } \\
\text { 99- SEMI }\end{array}$ & $\begin{array}{l}\text { O POR OUT } \\
\text { DIU-SE } \\
\text { O TB + AIDS } \\
\text { INFORMAÇA }\end{array}$ & CAUSA \\
\hline
\end{tabular}

\section{OBSERVAÇÕES}

\begin{tabular}{|l|l|}
\hline NOME DO RESPONSÁVEL PELO PREENCHIMENTO & CARIMBO DO CRM DO MEDICO RESPONSAVEL \\
\hline ASSINATURA DO RESPONSAVELL PELO PREENCHIMENTO & ASSINATURA DO MÉDICO RESPONSÁVEL \\
\hline
\end{tabular}

\section{INSTRUÇÕES PARA PREENCHIMENTO}

Preencher esta ficha para todo e qualquer doente que iniciar ou continuar o tratamento de tuberculose na Unidade, seja ele caso novo, reinicio de tratamento após abandono ou recebido por transferência, independentemente de já ter sido notificado anteriormente (a duplicidade de notificação será detectada por computador posteriormente).

Identificação: Nome: Anotar de forma legivel o nome completo, sem abreviar. Escolaridade: Anos de estudo concluidos. Exemplo: se o paciente estudou ate a $1^{\text {a }}$ série do $2^{\circ} \mathrm{grau}$, a escolaridade $=9$ ( 8 anos do $1^{\circ} \mathrm{grau}+1$ ano do $\left.2^{\circ} \mathrm{grau}\right)$. Ocupaçāo: profissão do paciente. Campo livre.

Tipo de ocupação: classificar segundo as situaçōes de risco aumentado de exposição à tuberculose listadas nos códigos.

Tratamento anterior: NÃO (1) : significa que o paciente informa que nunca fez tratamento de tuberculose anteriomente. Se o paciente não sabe se fez tratamento de $T B$, assinalar a opção NÃO SABE (4). Se houve um tratamentn anterior já encerrado, por cura, assinalar a opção (2) e a opçāo (3) se o mesmo term.... ": por abandono. ATENÇĀO: Se o paciente veio transferido para continuidade do primerro tratamento de tuberculose, assinalar o código 1. Para casos crônicos, assinalar o tipo de alta do último tratamento encerrado.

Forma clinica: Registrar a forma ou formas clinicas de tuberculose, conforme os códigos relacionados.

Descoberta: Tipo de descoberta - Assinalar a forma de descoberta do caso. Serviço que descobriu o caso: Este código deve corresponder à classificação do serviço que primeiro fez a suspeita e/ou diagnóstico de tuberculose; em caso de descoberta no próprio serviço notificante, sua categoria deve ser levada em conta. Os códigos referentes aos serviços universitários podem corresponder a serviços públicos ou nāo, desde que sejam ligados a faculdades de Medicina elou Enfermagem.
Tempo dos sintomas: informar o tempo total em semanas, do inicio dos sintomas da tuberculose ate 0 inicio do tratamento.

Baciloscopia e cultura. BACILOSCOPIA DE ESCARRO: campo reservado exclusivamente ao resultado do exame baciloscópico direto de escarro, realizado por ocasião do diagnóstico. Caso tenha sido feito exame de lavado gástrico, lavado bronco-alveolar, assinalar como baciloscopia de outro material. Se o exame estiver em andamento, informar posteriormente o resultado à vigilància epidemiológica. Raio X e histopatológica: RAIO X: Classificar como suspeita de TB o exame radiológico compativel com qualquer forma de tuberculose. HISTOPATOLOGICO: Resultados de biópsia sugestivos são aqueles em que o exame anatomopatológico revela granuloma com processo caseoso, com ou sem a visualização de bacilos àlcool-ácido resistentes.

Doenças associadas: Não havendo doenças associadas, registrar o código 6. Anti-HIV: Considerar o teste positivo mesmo que esse resultado provenha de exame realizado em outro serviço.

Tratamento atual: DATA DE INICIO - corresponde à data em que o doente iniciou a tomada de medicamentos para tuberculose, mesmo que isso tenha ocorrido em outro serviço de saudde. DROGAS - Preencher com as drogas especificas anti-tuberculose prescritas inicialmente para o tratamento. Em caso de mudança de esquema, esse fato deverá ser comunicado posteriormente à vigilância epidemiológica

Contatos: Informar o total de pessoas que residem com o paciente, o número dessas pessoas que compareceram para o exame e quantos adoeceram de tuberculose. Caso esses dados não sejam disponiveis atè a data de envio da ficha, informar posteriormente à vigilância epidemiológica.

Internação: informar se o paciente foi ou năo internado, a data de internação e o motivo principal, a data de alta hospitalar e o tipo de alta. ATENÇẢO: Se o paciente foi encaminhado para outro serviço, assinalar no item observaçöes para qual serviço o paciente foi encaminhado. 
QUALIDADE DA BUSCA DE CASOS POR MUNICÍPIO DE RESIDÊNCIA - ALPHA .44

B1 - Demora sintomas/tratamento até 8 semanas

B2 - Procura de Sintomáticos Respiratórios (busca ativa ou na demanda do serviço)

$\star \star \star \star \star \star$ Method 2 (covariance matrix) will be used for this analysis $* \star \star \star * *$

RELIABILITYANALYSIS-SCALE (A I P H A)

Correlation Matrix

RB1 B2

B1 1.0000

B2

$$
.3066 \quad 1.0000
$$

$\mathrm{N}$ of Cases $=\quad 57.0$

Inter-item

Correlations

$\begin{array}{rrrrrr}\text { Mean } & \text { Minimum } & \text { Maximum } & \text { Range } & \text { Max/Min } & \text { Variance } \\ .3066 & .3066 & .3066 & .0000 & 1.0000 & .0000\end{array}$

Item-total statistics

$\begin{array}{ccccc}\text { Scale } & \text { Scale } & \text { Corrected } & & \\ \text { Mean } & \text { Variance } & \text { Item- } & \text { Squared } & \text { Alpha } \\ \text { if Item } & \text { if Item } & \text { Total } & \text { Multiple } & \text { if Item } \\ \text { Deleted } & \text { Deleted } & \text { Correlation } & \text { Correlation } & \text { Deleted }\end{array}$

$\begin{array}{lllll}\text { B1 } & 36.8632 & 387.2517 & .3066 & .0940 \\ \text { B2 } & 66.4175 & 192.1300 & .3066 & .0940\end{array}$

Reliability Coefficients

2 items

Alpha $=.4480$

Standardized item alpha $=.4693$ 


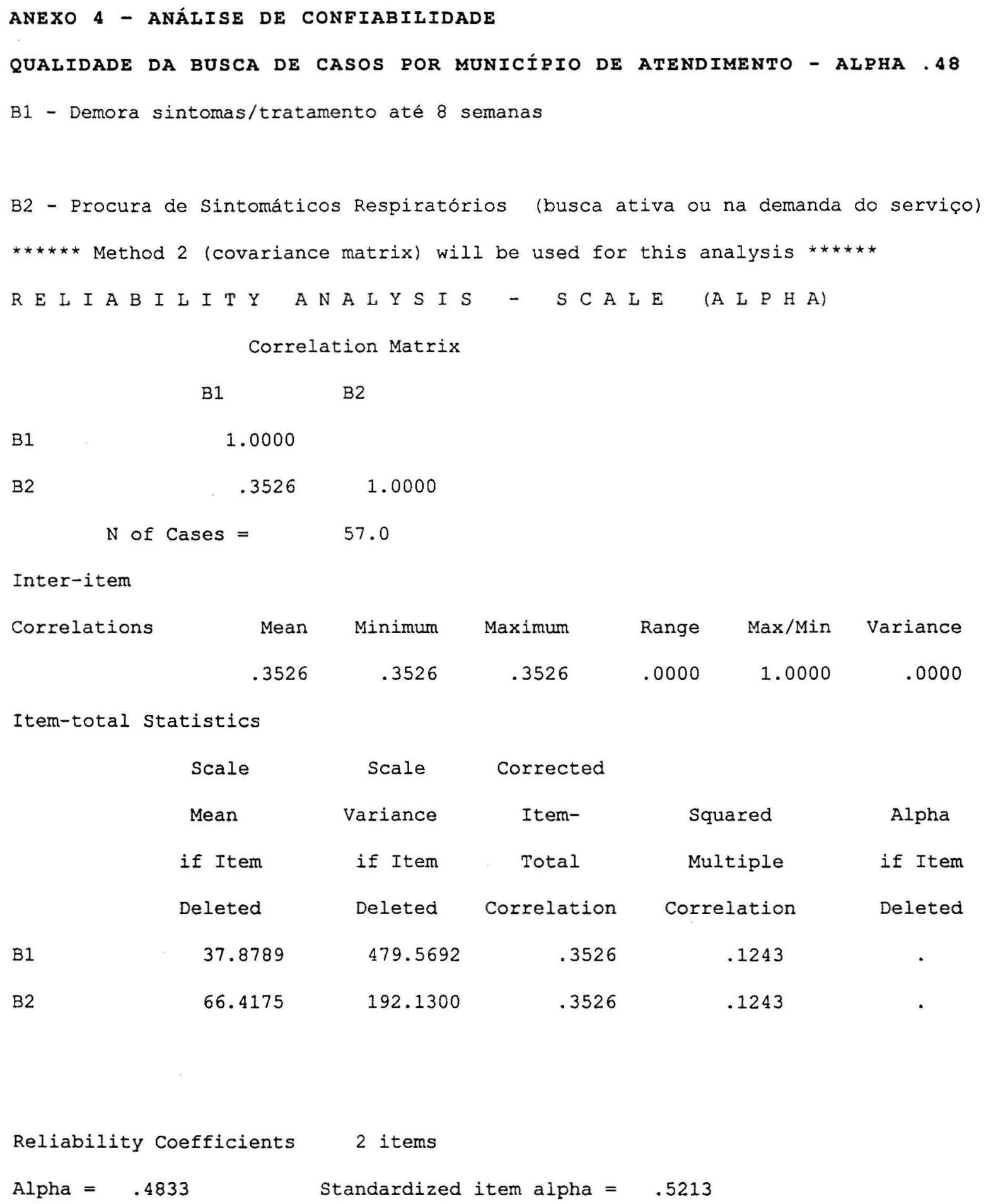

$\begin{array}{lcccc}\text { Scale } & \text { Scale } & \text { Corrected } & & \\ \text { Mean } & \text { Variance } & \text { Item- } & \text { Squared } & \text { Alpha } \\ \text { if Item } & \text { if Item } & \text { Total } & \text { Multiple } & \text { if Item } \\ \text { Deleted } & \text { Deleted } & \text { Correlation } & \text { Correlation } & \text { Deleted } \\ 37.8789 & 479.5692 & .3526 & .1243 & . \\ 66.4175 & 192.1300 & .3526 & .1243 & .\end{array}$


D1 - Realização de baciloscopia para diagnóstico dos casos pulmonares $>14$ anos

D2 - Confirmação bacteriológica total

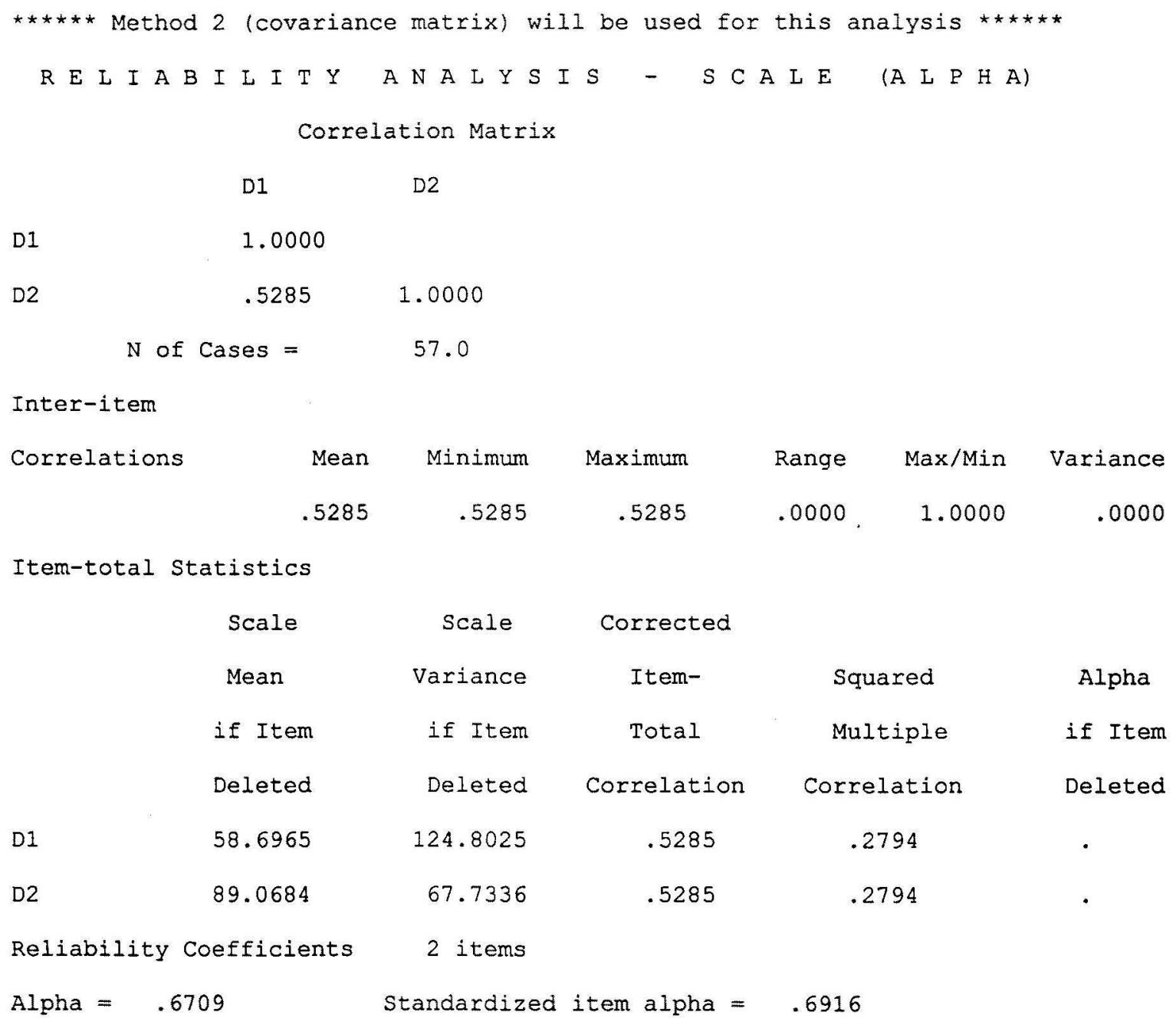


ANEXO 6 - ANÁLISE DE CONEIABILIDADE

QUALIDADE DO DIAGNÓSTICO POR MUNICÍPIO DE ATENDIMENTO - ALPHA . 69

D1 - Realização de baciloscopia para diagnóstico dos casos pulmonares > 14 anos

D2 - Confirmaçăo bacteriológica total

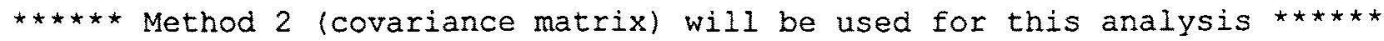

R E L I A B I I T Y A N A I S I S - S CAIE (A I P H A)

Correlation Matrix

D1 D2

D1 1.0000

D2

$.5630 \quad 1.0000$

$\mathrm{N}$ of Cases $=$

57.0

Inter-item

Correlations

Mean Minimum

Maximum

Range Max/Min

Variance

.5630

.5630

.5630

.0000

1.0000

.0000

Item-total Statistics

\begin{tabular}{|c|c|c|c|c|c|}
\hline & Scale & Scale & Corrected & & \\
\hline & Mean & Variance & Item- & Squared & Alpha \\
\hline & if Item & if Item & Total & Multiple & if Item \\
\hline & Deleted & Deleted & Correlation & Correlation & Deleted \\
\hline $\mathrm{D} 1$ & 58.8895 & 153.0620 & .5630 & .3170 & - \\
\hline$D 2$ & 88.9439 & 77.5814 & .5630 & .3170 & . \\
\hline Reliability & Coefficients & 2 items & & & \\
\hline Alpha $=$ & 5945 & Standardized & item alpha $=$ & .7204 & \\
\hline
\end{tabular}




\section{ANEXO 7 - ANÁLISE DE CONFIABILIDADE}

QUALIDADE Do TRATAMENTO POR MUNICÍPIO DE RESIDÊNCIA - ALPHA .59

T1 - Taxa de cura

T2 - Controle bacteriológico ( 2 ou mais baciloscopias)

T3 - Negativação da baciloscopia

T4 - Realização de teste para HIV

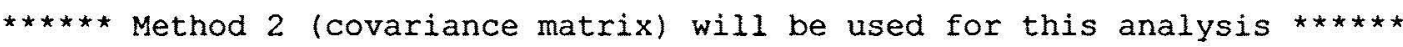

RELIA B I L I T Y A N A I Y IS - S C A L E (A I P H A)

Correlation Matrix

T1

1.0000

T1

T2

T3

T4

.1701

$\mathrm{N}$ of Cases $=$

.0279
$\mathrm{T} 2$

T3

T4

1.0000

.1905

1.0000

.3123

.4372

1.0000

57.0

Inter-item

Correlations

$\begin{array}{lr}\text { Mean } & \text { Minimum } \\ .2817 & .0279\end{array}$

Maximum

Range

Max/Min

Variance

.5519

$.5240 \quad 19.7664$

.0333

Item-total Statistics

Scale
Mean
if Item
Deleted

Scale

Corrected

$$
\text { Variance }
$$

Item-

Squared

Alpha

if Item

Total

Multiple

if Item

Deleted

Correlation

Correlation

Deleted

$\begin{array}{lr}\text { T1 } & 188.3719 \\ \text { T2 } & 165.0544 \\ \text { T3 } & 135.5228 \\ \text { T4 } & 133.7193 \\ \text { Reliability Coefficients } \\ \text { Alpha }= & .5920\end{array}$

1590.1635

.4475

.3119

.4775

849.6136

.5352

.3613

.4041

2084.3114

.2902

.2027

.6001

1538.6919

.3690

.2467

.5238

4 items

Standardized item alpha $=.6107$ 
ANEXO 8 - ANÁLISE DE CONEIABILIDADE

QUALIDADE Do TRATAMENTO POR MUNiCíPIO DE ATENDIMENTO - ALPHA .59

T1 - Taxa de cura

$\mathrm{T} 2$ - Controle bacteriológico ( 2 ou mais baciloscopias)

T3 - Negativação da baciloscopia

T4 - Realização de teste para HIV

Method 2 (covariance matrix) will be used for this analysis

REI I A I I I T ANALYSIS- SCALE (A L P A ) Correlation Matrix

$\begin{array}{llll}\text { T1 T2 T3 } & \text { T2 }\end{array}$

$\begin{array}{lrrrr}\text { T1 } & 1.0000 & & & \\ \text { T2 } & .6294 & 1.0000 & & \\ \text { T3 } & .0800 & .1416 & 1.0000 & \\ \text { T4 } & .2522 & .2617 & .2334 & 1.0000\end{array}$

$\mathrm{N}$ of Cases $=\quad 57.0$

Inter-item

Correlations Mean Minimum Maximum Range Max/Min Variance

$\begin{array}{llllll}.2664 & .0800 & .6294 & .5494 & 7.8674 & .0333\end{array}$

Item-total statistics

\begin{tabular}{|c|c|c|c|c|c|}
\hline & Scale & Scale & Corrected & & \\
\hline & Mean & Variance & Item- & Squared & Alpha \\
\hline & if Item & if Item & Total & Multiple & if Item \\
\hline & Deleted & Deleted & Correlation & Correlation & Deleted \\
\hline $\mathrm{T} 1$ & 198.3614 & 1601.2042 & .5817 & .4052 & .3694 \\
\hline $\mathrm{T} 2$ & 175.3228 & 917.2043 & .5588 & .4123 & .3985 \\
\hline T3 & 142.0754 & 2513.1912 & .1870 & .0627 & .6350 \\
\hline $\mathrm{T} 4$ & 138.3561 & 2044.9443 & .3183 & .1210 & .5660 \\
\hline Reliability & Coefficients & 4 items & & & \\
\hline Alpha = & 5951 & Standardized & item alpha = & .5923 & \\
\hline
\end{tabular}

